Petroleum Science and Engineering

Elsevier Editorial System(tm) for Journal of Manuscript Draft

Manuscript Number: PETROL12057R4

Title: Unraveling the reservoir heterogeneity of the tight gas sandstones using the porosity conditioned facies modeling in the Whicher Range field, Perth Basin, Western Australia

Article Type: Full Length Article

Keywords: Tight sandstones, modeling, sedimentary characteristics, diagenesis, reservoir heterogeneity

Corresponding Author: Mr. rahim kadkhodaee,

Corresponding Author's Institution: Nargan Amitis Energy Development Company

First Author: rahim kadkhodaee

Order of Authors: rahim kadkhodaee; Ali Kadkhodaie; Reza Rezaee; Vali Mehdipour

Abstract: Tight sandstones of the late Permian Willespie Formation constitute an important reservoir rock in the whicher Range gas field of the Perth Basin. The sandstones under the effect of sedimentary conditions and diagenesis show some degree of heterogeneity reflecting in reservoir properties and production history. The Willespie Formation consists of fine to coarse-grained and gravelly feldspathic sandstones intercalated with shale, siltstone and coal, deposited in a meandering river system. Different diagenetic processes including compaction, cementation (authigenic clays, calcite and siliceous) and dissolution have severely affected the pore system properties of the reservoir sandstones, as they are considered as tight sandstones. In this study, three-dimensional modeling of reservoir sandstones has been performed using stochastic modeling algorithms for facies and porosity properties. A preliminary facies analysis of the main reservoir rocks based on core and well logs data provided the basis for reservoir zonation and modeling. Regarding the close relationship between acoustic impedance with depositional/diagenetic characteristics of reservoir facies and their porosity, this seismic attribute was used as a secondary parameter in porosity modeling. The results indicate a close relationship between sedimentary characteristics and reservoir properties. Based on the extracted models, most of the porous zones are related to the clean and coarse sandstones of the fluvial channels accumulating in the upper parts of the reservoir. In fact, initial sedimentary characteristics have the main impact on the distribution of reservoir zones, their thickness and continuity in the field and controlling large-scale reservoir heterogeneity which has been enhanced by the effect of diagenetic processes on the pore system properties and controlling the internal reservoir heterogeneity in next stages. Distinctive variability in reservoir properties towards the upper reservoir units and also among different wells can be considered for optimizing exploration and development targets of the field. 
Research Data Related to this Submission

There are no linked research data sets for this submission. The following reason is given:

The authors do not have permission to share data 


\title{
Unraveling the reservoir heterogeneity of the tight gas sandstones using the porosity conditioned facies modeling in the Whicher Range field, Perth Basin, Western Australia
}

\begin{abstract}
Tight sandstones of the late Permian Willespie Formation constitute an important reservoir rock in the Whicher Range gas field of the Perth Basin. The sandstones under the effect of sedimentary conditions and diagenesis show some degree of heterogeneity reflecting in reservoir properties and production history. The Willespie Formation consists of fine to coarse-grained and gravelly feldspathic sandstones intercalated with shale, siltstone and coal, deposited in a meandering river system. Different diagenetic processes including compaction, cementation (authigenic clays, calcite and siliceous) and dissolution have severely affected the pore system properties of the reservoir sandstones, as they are considered as tight sandstones. In this study, three-dimensional modeling of reservoir sandstones has been performed using stochastic modeling algorithms for facies and porosity properties. A preliminary facies analysis of the main reservoir rocks based on core and well logs data provided the basis for reservoir zonation and modeling. Regarding the close relationship between acoustic impedance with depositional/diagenetic characteristics of reservoir facies and their porosity, this seismic attribute was used as a secondary parameter in porosity modeling. The results indicate a close relationship between sedimentary characteristics and reservoir properties. Based on the extracted models, most of the porous zones are related to the clean and coarse sandstones of the fluvial channels accumulating in the upper parts of the reservoir. In fact, initial sedimentary characteristics have the main impact on the distribution of reservoir zones, their thickness and continuity in the field and controlling large-scale reservoir heterogeneity which has been enhanced by the effect of diagenetic processes on the pore system properties and controlling the internal reservoir heterogeneity in next stages. Distinctive variability in reservoir properties towards the upper reservoir units and also among different wells can be considered for optimizing exploration and development targets of the field.
\end{abstract}




\author{
Dear Editor-in-Chief \\ Journal of Petroleum Science and Engineering
}

The authors would like to thank the editor and reviewers for their consideration and evaluation of the manuscript. All comments of the respected reviewer were considered in the revised version of the manuscript. All changes have been highlighted in the revised manuscript (in red color), and also comments from the reviewer point-by-point have been answered in below.

Sincerely Yours

Rahim Kadkhodaie (Corresponding Author)

Earth Sciences Department

Faculty of Natural Science

University of Tabriz, Tabriz, Iran

Cell phone: +989128457310

Email: rahimkadkhodaee2005@yahoo.com; rahimkadkhodaee2005@gmail.com

Reviewer \#4: Dear authors, I would like to thank your effort including my recommendations in the revised version of the document. I still have some minor comments that I would like to see addressed before proceeding with the recommendation for publication. Please find them below:

We are very grateful for informative and constructive comments from the respected reviewer. These comments were considered in the revised manuscript (highlighted in red color), and also are answered as follows.

1) Remove abbreviations from abstract Abbreviations were removed from Abstract.

2) L24. Should read "using stochastic modelling algorithms" This was included in Line 24 (page 1).

3) It is my opinion that the text added in lines 149-153 should be further explored to include a more formal description of the clustering method.

Clustering method was more described in lines 146-156 (page 6).

4) Related with my previous comment "My second main concern is related to the way porosity is generated. The authors are using again Ip as secondary but you do not say what is the global correlation coefficient between both properties? Then, why do you model facies if porosity is not faciesconditioned? I do not see the link between both modelling procedures". I understand the comment, I do not necessarily agree with the adopted methodology, but this must be stated in the text. And it is not.

As it has been discussed in this research, tight sandstones of the field under the effect of their primary depositional characteristics and also diagenesis are heterogeneous. One main reason for using AI as secondary parameter in porosity modeling of tight gas sandstones of the field is based on the results from previous study (Kadkhodaie-Ilkhchi et al., 2014), which indicates variations in AI can be interpreted based on depositional, diagenetic and petrophysical characteristics of the reservoir sandstones. This also has been mentioned in lines 491-495 (page 
22) of the manuscript. So, we consider it as an effective parameter which in addition to its inverse relationship with porosity (Figure 18, page 23), reflects facies and diagenetic characteristics of heterogeneous tight sandstones of the field.

Facies model in fact shows distribution of all facies (clean sandstones $(\mathrm{GR}<80)$; silty/shaly units $(\mathrm{GR}>130)$; fine-grained and silty sandstones $(80<\mathrm{GR}<130)$ ) which based on the vertical and lateral variability in reservoir properties in the field and between the wells is interpreted (as discussed in lines 630-641, and Figures 24 and 25), but porosity modeling has been more focused on clean sandstones, as the main reservoir zones in the studied field.

Co-kriging window for this parameter as secondary variable used in porosity modeling, for some reservoir zones has been shown on the last pages.

5) I still think that the variogram models for porosity should be shown as the main objective is porosity modelling.

Samples of the extracted variogram models for porosity have been shown in Figure 16 (page 20). In fact, in this study variogram models were extracted for different zones of the reservoir interval, but they have been shown only for one zone in the manuscript.

6) Fig 22 is not very informative. I do not see the objective of this figure. Do you have a blind well to test the inverted Ip model and the inferred porosity? This will add a tremendous value to your work. This figure was removed from the manuscript. In fact, it had been used to show general increasing trend of porosity toward the upper parts of the reservoir interval. Unfortunately, blind well was not available to check the results.

7) Pay attention to the quality of figures 19, 20 and 21. Also, figure 19 should have the same scale as the other two. Same for Fig. 17

Figures 17, 19, 20 and 21 were replaced by new ones with higher quality (pages 21, 24, 25, 26). Also, similar scale was used for Figure 19 (page 24). 

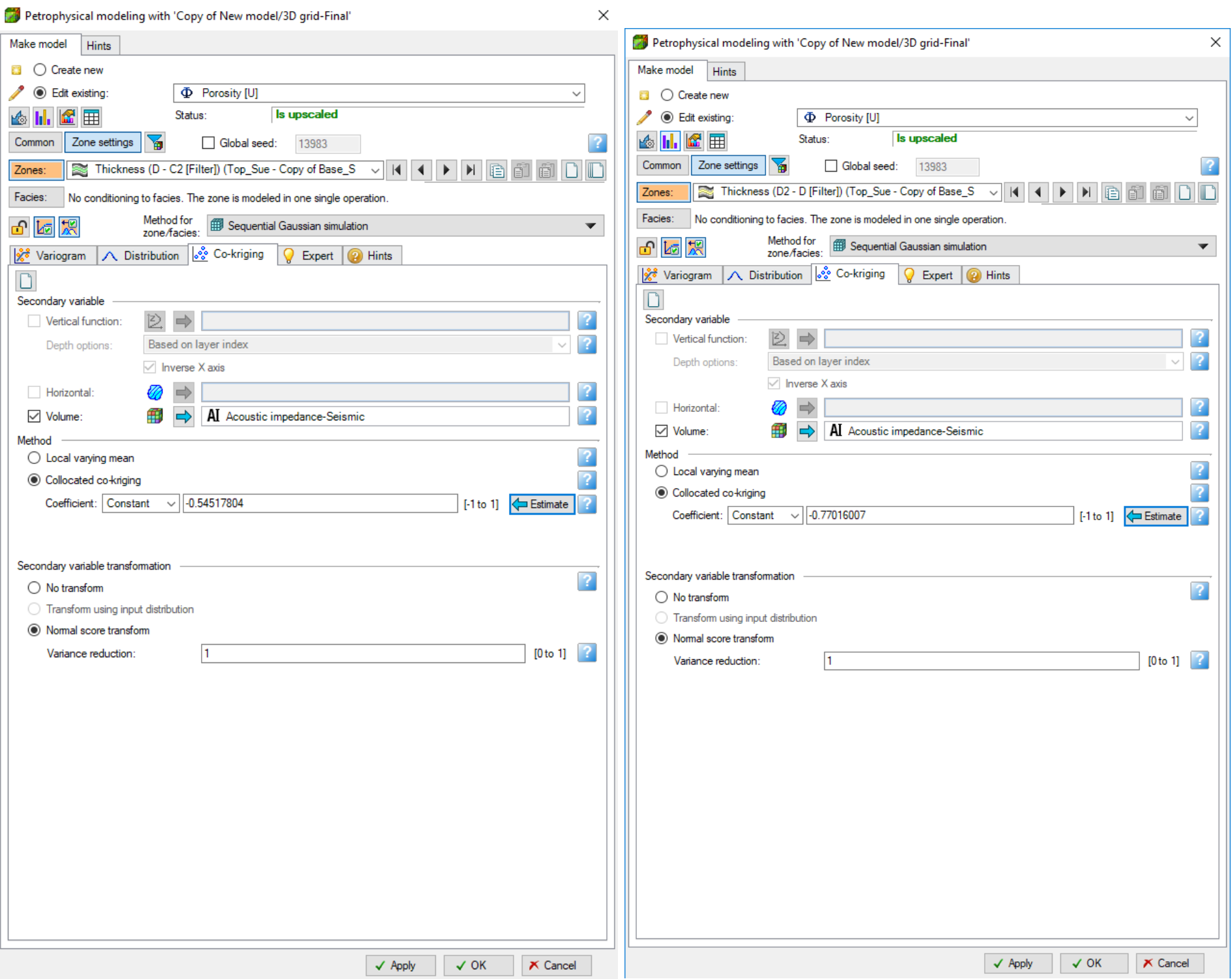

39

40

Co-kriging window showing the use of acoustic impedance as secondary variable in porosity modeling of tight sandstones of the studied field. 

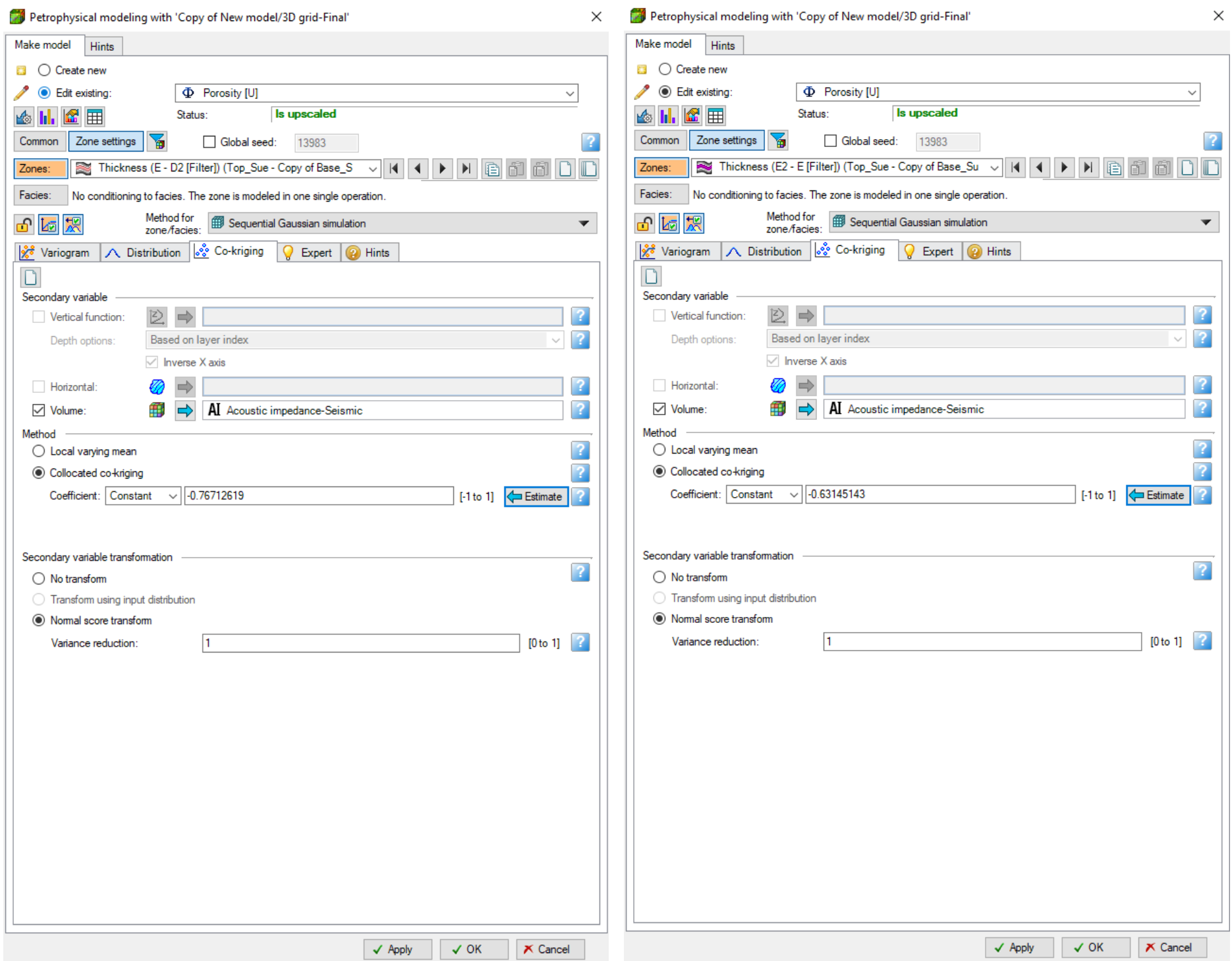

Co-kriging window showing the use of acoustic impedance as secondary variable in porosity modeling of tight sandstones of the studied field. 


\section{Unraveling the reservoir heterogeneity of the tight gas sandstones using the} porosity conditioned facies modeling in the Whicher Range field, Perth Basin, Western Australia

Rahim Kadkhodaie-Ilkhchi $^{1 *}$, Ali Kadkhodaie ${ }^{1}$, Reza Rezaee ${ }^{2}$, Vali Mehdipour ${ }^{3}$

1. Earth Science Department, Faculty of Natural Science, Tabriz, Iran

2. Department of Petroleum Engineering, Curtin University, Perth, Australia

3. DanaEnergy Company, Tehran, Iran

*Corresponding author: Tel./fax: +98 9128457310

E-mail: rahimkadkhodaee2005@gmail.com, rahimkadkhodaee2005@yahoo.com (R. KadkhodaieIlkhchi); kadkhodaie_ali@tabrizu.ac.ir (A. Kadkhodaie -Ilkhchi); r.rezaee@curtin.edu.au (R. Rezaee); mehdipour.vali@gmail.com (V. Mehdipour)

\section{Abstract}

Tight sandstones of the late Permian Willespie Formation constitute an important reservoir rock in the Whicher Range gas field of the Perth Basin. The sandstones under the effect of sedimentary conditions and diagenesis show some degree of heterogeneity reflecting in reservoir properties and production history. The Willespie Formation consists of fine to coarse-grained and gravelly feldspathic sandstones intercalated with shale, siltstone and coal, deposited in a meandering river system. Different diagenetic processes including compaction, cementation (authigenic clays, calcite and siliceous) and dissolution have severely affected the pore system properties of the reservoir sandstones, as they are considered as tight sandstones. In this study, three-dimensional modeling of reservoir sandstones has been performed using stochastic modeling algorithms for facies and porosity properties. A preliminary facies analysis of the main reservoir rocks based on core and well logs data provided the basis for reservoir zonation and modeling. Regarding the close relationship between acoustic impedance with depositional/diagenetic characteristics of reservoir facies and their porosity, this seismic attribute was used as a secondary parameter in porosity modeling. The results indicate a close relationship between sedimentary characteristics and reservoir properties. Based on the extracted models, most of the porous zones are related to the clean and coarse sandstones of the fluvial channels accumulating in the upper parts of the reservoir. In fact, initial sedimentary characteristics have the main impact on the distribution of reservoir zones, their thickness and continuity in the field and controlling large-scale reservoir heterogeneity which has been enhanced by the effect of diagenetic processes on the pore system properties and 
37 controlling the internal reservoir heterogeneity in next stages. Distinctive 38 variability in reservoir properties towards the upper reservoir units and also among 39 different wells can be considered for optimizing exploration and development 40 targets of the field.

41 Keywords: Tight sandstones, modeling, sedimentary characteristics, diagenesis, 42 reservoir heterogeneity

\section{$43 \quad$ 1. Introduction}

Tight gas sandstones are considered as a part of unconventional reservoirs in the world and especially in Australia. These reservoirs are mainly characterized by in situ permeability less than 0.1md (Rezaee et al., 2012; Zou et al., 2012). Challenges to reach the optimum production from these reservoirs indicate the complex nature of their pore system related to depositional and post-depositional controlling factors. Tight reservoir sandstones of the Whicher Range field in the Perth Basin of Western Australia, the target of this study, under the effect of primary sedimentary characteristics and diagenetic processes, show some complexities in pore system and reservoir properties affecting their production behavior in the field. The inherent reservoir heterogeneity and complexity observed in reservoir characteristics of tight gas systems means they should be treated with more caution for reservoir characterization targets, as these factors can lead to significant errors in estimation of reservoir properties, and finally misleading interpretations (Kulga et al., 2018). In recent years, many authors discussed the reservoir heterogeneity and pore system properties of tight sandstone reservoirs (e.g., Hsieh et al., 2017; Huang et al., 2017; Dou et al., 2017; Lai et al., 2017; Du et al., 2018). Some researchers have particularly highlighted the importance of diagenesis on reservoir properties of these reservoirs (e.g., Li et al., 2017; Lai et al., 2018; Oluwadebi et al., 2018; Xiao et al., 2018). Many works have been accomplished to reveal heterogeneity and reservoir characteristics of tight sandstone reservoirs through different modeling approaches (e.g., Zhi et al., 2015; Wei et al., 2016; Mahgoub et al., 2018). Investigation of tight sandstones of the Whicher Range field in the framework of a3D model of facies and petrophysical properties, accomplished in this study, can efficiently provide a comprehensive sense of the distribution of the reservoir zones in the field and identification the main factors controlling the reservoir quality. To meet these targets, a 
comprehensive investigation of depositional characteristics and diagenetic features of sandstone facies and their reservoir properties, through analysis of core and well logs data, was performed. Reservoir rock types were differentiated based on cluster analysis of well logs (especially GR), and were correlated between the wells. Three-dimensional geocellular models of facies and porosity properties based on stochastic algorithms were extracted. As a result, the extracted models were used to describe the reservoir heterogeneity of tight sandstones in both the large scale related to depositional characteristics, and the small scale related to the effect of diagenetic processes on pore system properties.

\section{Geology, tectonic setting and stratigraphy}

Perth Basin is considered as a rift basin with north-south trending which has been located on the western border of Western Australia and adjacent to Yilgarn Craton (Fig. 1A). Darling Fault in the eastern part of the basin has exerted significant control on its formation. The basin formation and evolution is related to two main tectonic phases with tensional system. The first phase which has been occurred in the late Permian is associated with the formation of a rifting basin. The second event which is correlated with the breakup and separation of Australia plate from India has occurred during the late Jurassic to early Cretaceous (Quaife et al. 1994; Marshall et al. 1989; Mory and Iasky, 1996).The basin contains mainly clastic rocks deposited in a developing rift system from Permian to recent (Owad-Jones and Ellis, 2000). Whicher Range field is located $200 \mathrm{~km}$ south of Perth and $22 \mathrm{~km}$ south of the city of Busselton in Western Australia. This field is a large faulted anticline with the northeast trend in the Bunbury Trough (Fig. 1B), formed as a result of intense strike-slip movements during continental breakup (Crostella and Backhouse, 2000; Owad-Jones and Ellis, 2000; Sharifzadeh, 2008).The Permian interval of Bunbury Trough includes the Sue Group that is subdivided into five formations including the Woodynook Sandstone, Rosabrook Coal Measures, Ashbrook Sandstone, Redgate Coal Measures, and Willespie Formation, in ascending order. These formations consist predominantly of poorly-sorted feldspathic sandstone deposited in clastic system. The Sandstone beds of the Willespie Formation with the late Permian in age constitute the reservoir zone of the field (Fig. 2A).This Formation lies conformably above the Redgate Coal Measures Formation, and the upper boundary with the Triassic Sabina Sandstone is apparently conformable (Crostella and Backhouse, 2000). Coal and carbonaceous 
104 shales within the interval are considered as hydrocarbon sources, as it said the 6105 reservoir sandstones have a self-sourcing rock (Tobin et al., 2010). Shales,
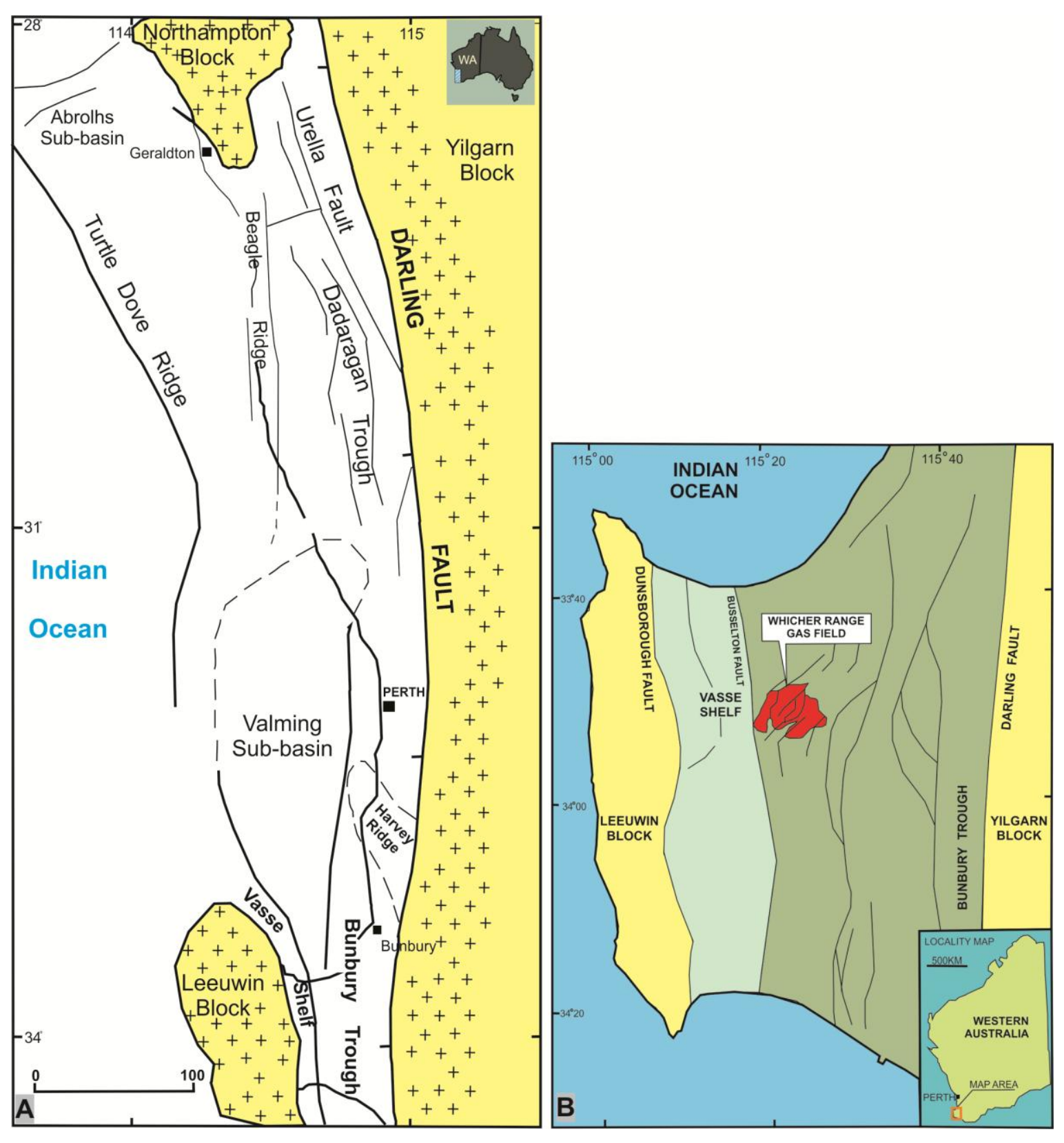
carbonaceous siltstones and coals have acted as intraformational cap rocks and permeability barriers for the reservoir sandstones of the field.

Fig. 1: A) General map of the Perth Basin in Western Australia (modified after Hall and Kneale, 1992). B) Location of the Whicher Range gas field in the Perth Basin (modified after 111 Sharifzadeh, 2008). 

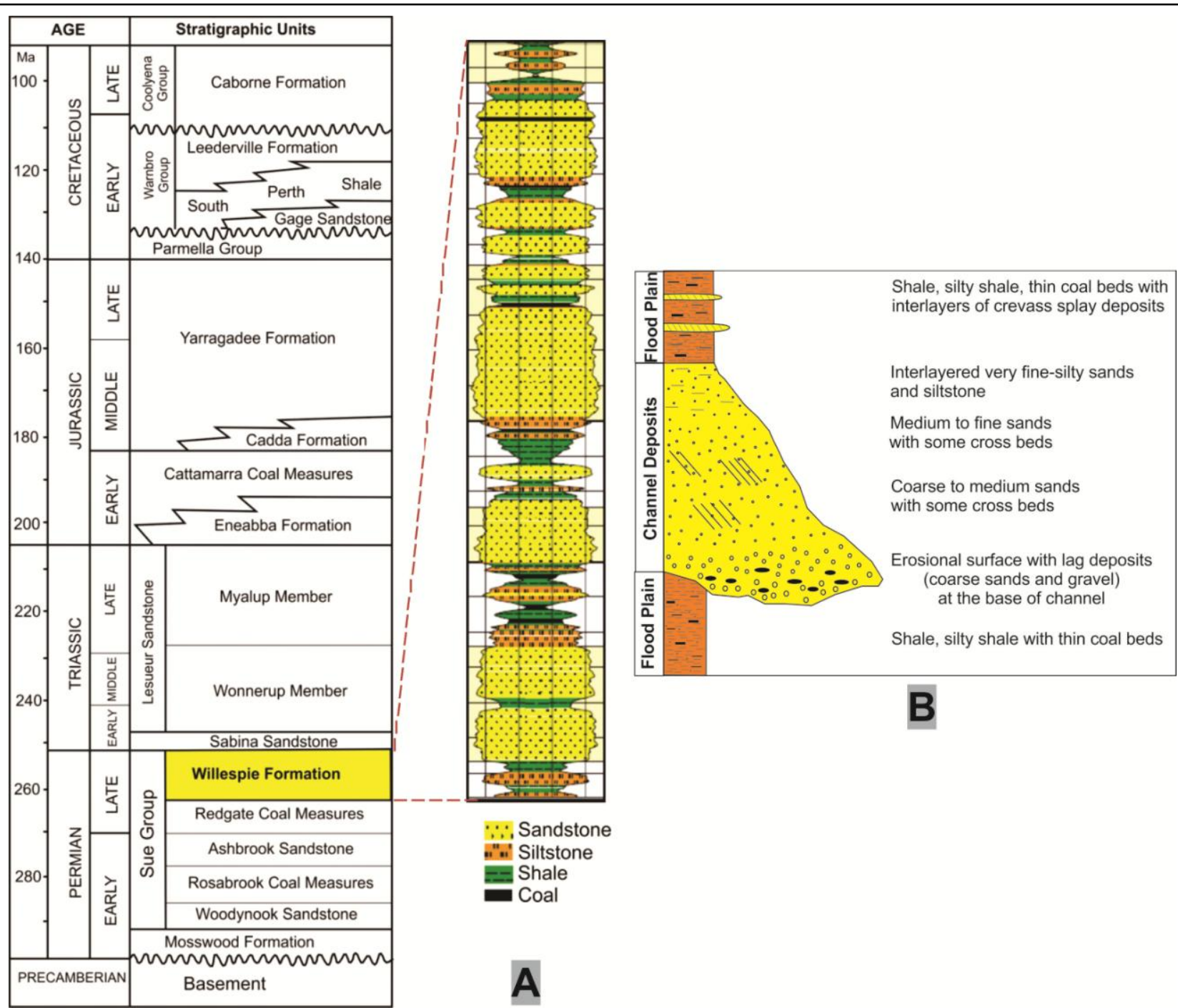

Fig.2: A) Stratigraphy succession of the southern Perth Basin (Playford et al., 1976). The late Permian Willespie Formation, as reservoir rock of the Whicher Range field, with lithology composed of sandstone, siltstone, shaleand coal is highlighted in the stratigraphic column. B) A schematic picture showing fining upward interval of the Willespie sandstones within a meandering river system environment.

\section{Data and Methodology}

In this study, in order to model and investigate facies and reservoir characteristics of the Willespie Formation sandstones in the Whicher Range field, core/cutting 122 and well log data and information from five drilled wells (WR1, WR2, WR3, WR4 123 and WR5) in the field, provided by Curtin University of Technology, Department 
of Petroleum Engineering, with input from Department of Mines and Petroleum (WAPIMS) and Whicher Range Energy, were used. Available core data are from four wells (WR1 to WR4) in several intervals of the Willespie Formation.

At the first stage of this study, sedimentary characteristics of the reservoir rocks, based on the results from core and cutting description (lithofacies) associated with petrographic studies (petrofacies) in five wells were inspected. The main diagenetic processes including compaction, cementation and dissolution were described and interpreted based on the results from petrography and SEM analysis. Then,reservoir characteristics of sandstone facies through core poroperm data analysis were studied, and correlated with their compositional and textural characteristics, dominant diagenetic features and pore types by which the main factors controlling the reservoir quality and pore system properties of tight sandstones in the field were recognized. At the second stage, in order to reach a comprehensive understanding of the factors controlling the internal reservoir heterogeneity and analyze the distribution of reservoir zones in the field, facies and porosity attitudes of reservoir sandstones were investigated through geostatistical modeling. For facies modeling, Sequential Indicator Simulation (SIS), as proposed by many researchers (e.g., Journel and Alabert, 1988; Deutsch and Journel, 1998; Dubrule, 2003; Caers, 2000; Kiaei et al., 2015), and for porosity modeling, Sequential Gaussian Simulation (SGS) as a common stochastic method introduced in the literature (e.g., Albertão et al., 2001; Martinius et al., 2017) were used. Facies codes extracted from previous work (i.e., Kadkhodaie-Ilkhchi et al., 2013) through well logs (especially GR) clustering technique were utilized. This technique that analyzes a data set (well logs), classifies log data into subsets (clusters), in which each cluster shows specific attitudes of well logs responses. In this respect, the first step is to compute the distance between data objects (well log data) based on a distance function (e.g., Euclidean function). In the next step, linking between distance data is made using an appropriate linkage function (e.g., Ward function), which based on a hierarchical cluster tree or dendrogram is generated. Different clusters in the dendrogram are hierarchically linked together from small clusters with higher similarity degree to large clusters having lower similarity degree. In the final step, using a set of cutoff values, clusters are extracted from dendrogram. As a result, three main facies including clean sandstones $(\mathrm{GR}<80)$, silty sandstones $(80<\mathrm{GR}<130)$, and shale $(\mathrm{GR}>130)$ are 
identified. These facies also were correlated with the sedimentary characteristics derived from core studies. To start the reservoir modeling, one interpreted structure map from the top of the Willespie Formation and fault data in association with petrophysical logs (GR, DT, RHOB and NPHI) of five drilled wells were employed to build the framework of the model. Finally, the resultant facies and porosity models were extracted by geostatistical methods (i.e., stochastic algorithms such as SIS and SGS) which based on the variation and distribution of these characteristics in the field are discussed.

\section{Facies and sedimentary environment of reservoir sandstones}

The Willespie Formation has a sedimentary interval consisting of fine to coarsegrained and gravelly feldspathic sandstones intercalated with shale, siltstoneand coal. This interval, based on the results from core description (lithology and depositional features and structures), vertical sedimentary sequence and regional geology has been developed in a meandering river system with low to medium sinuosity. Reservoir sandstones in this system can be categorized in five facies associations (FA1 to FA5) related to the channel, crevasse splay, levee, floodplain and paludal/lacustrine deposits (Table 1). Sandstone facies within the channels show a fining upward sequence in which coarse and gravelly sandstones with an erosional surface have been deposited as bed load at the base of the channel and fine-grained facies with decreasing the energy started to deposit at top of the sequence (Figure 2B). Low energy silty and shaly facies in association with coal constitute the floodplain and paludal deposits. Petrographic evidences demonstrate that quartz (mostly monocrystalline and minor polycrystalline), potassium feldspar and plagioclase are the main constituents of the sandstones, and rock fragments, micas (biotite and muscovite) and heavy minerals (garnet, zircon, tourmaline, epidote, magnetiteand goethite) have low frequency. Rock fragments are volcanic, metamorphic with afew chert and sedimentary types. Sandstones are clay-rich with weak sorting and subangular to subrounded grains. The sandstones are texturally and mineralogically immature to submature, and according to Folk et al (1970), they are classified as feldspathic to subfeldspathic arenite (Fig. 3). Textural and diagenetic characteristics as well as average poroperm values of the Willespie sandstones have been given in Table2. 
Table 1: Sedimentary characteristics of sandstones facies of the Willespie Formation derived

\begin{tabular}{|c|c|c|c|c|}
\hline $\begin{array}{c}\text { Facies } \\
\text { Association }\end{array}$ & Facies & $\begin{array}{c}\text { Sedimentary } \\
\text { feature/Structure }\end{array}$ & $\begin{array}{l}\text { Sedimentary } \\
\text { Environment }\end{array}$ & $\begin{array}{c}\text { Core Photograph } \\
\qquad 10 \mathrm{~cm} \\
\end{array}$ \\
\hline FA-1 & $\begin{array}{l}\text { Gravely and coarse } \\
\text { grained sandstone } \\
(\mathrm{Gmm}) \text {, massive to } \\
\text { cross-bedded medium } \\
\text { to fine -grained } \\
\text { sandstone (Sp, Sm) }\end{array}$ & $\begin{array}{l}\text { cross bedding, } \\
\text { fining -upward, } \\
\text { erosional surface }\end{array}$ & Channel fill & Gmm \\
\hline FA-2 & $\begin{array}{l}\text { Cross-laminated to } \\
\text { laminated medium to } \\
\text { fine-grained } \\
\text { sandstone (Sl, Sr), } \\
\text { siltstone }\end{array}$ & $\begin{array}{l}\text { Lamination, cross } \\
\text { lamination, } \\
\text { bioturbation }\end{array}$ & $\begin{array}{l}\text { Channel margin } \\
\text { (levees, bar } \\
\text { tops) }\end{array}$ & $\overrightarrow{\mathrm{Sr}}$ \\
\hline FA-3 & $\begin{array}{l}\text { Heterolitic lithology: } \\
\text { Sharp-based, massive, } \\
\text { laminated to ripple } \\
\text { cross-laminated and } \\
\text { bioturbated fine } \\
\text { sandstone ( } \mathrm{Sm}, \mathrm{Sr} \text {, } \\
\mathrm{Sb} \text { ), locally with } \\
\text { cross-bedded (Sx) } \\
\text { overlain by very fine } \\
\text { sandstone-siltstone } \\
\text { and siltstone }(\mathrm{Ht}, \mathrm{Hb} \text {, } \\
\text { Ml) }\end{array}$ & $\begin{array}{l}\text { Lamination, cross } \\
\text { lamination, cross - } \\
\text { bedding, fining } \\
\text { upward }\end{array}$ & Crevasse splay & $\frac{\mathrm{D}}{\mathrm{Sb}}$ \\
\hline FA-4 & $\begin{array}{l}\text { Planar laminated to } \\
\text { carbonaceous } \\
\text { mudstone (Ml), minor } \\
\text { interbedded very fine } \\
\text { sandstone and } \\
\text { mudstone (Ht) }\end{array}$ & $\begin{array}{l}\text { coarsening up and } \\
\text { fining upwards } \\
\text { trends }\end{array}$ & $\begin{array}{l}\text { Flood plain and } \\
\text { distal crevasse } \\
\text { splay }\end{array}$ & MI \\
\hline FA-5 & $\begin{array}{l}\text { Coal seams and } \\
\text { lamination }(C)\end{array}$ & $\begin{array}{l}\text { interlamination of } \\
\text { mudstone and } \\
\text { siltstone with thin } \\
\text { coals }\end{array}$ & Paludal deposit & G \\
\hline
\end{tabular}



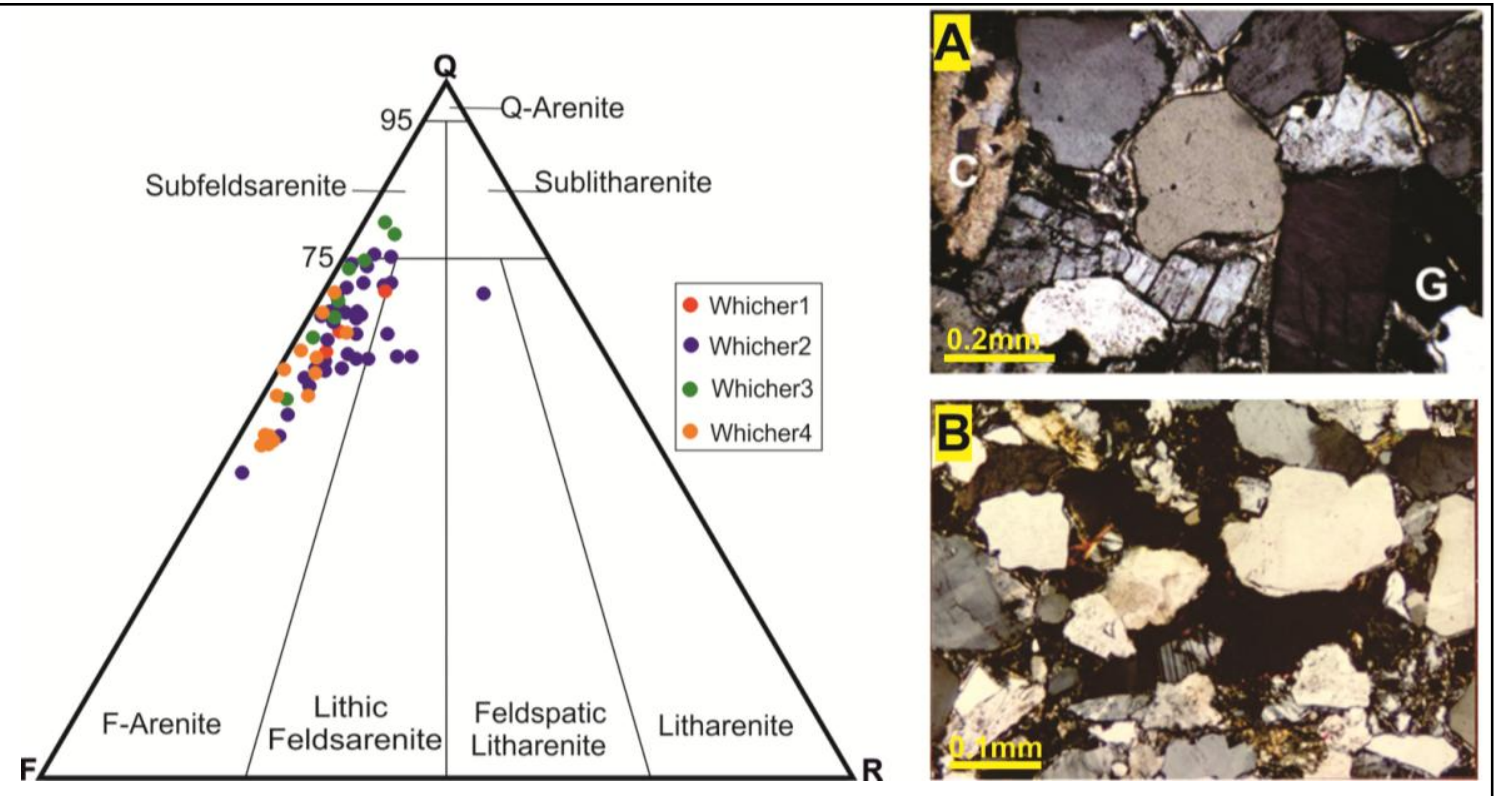

Fig.3: QFR plot of the Whicher Range sandstones showing the majority are feldspathic with some sub-feldspathic arenite. Q: monocrystalline and polycrystalline quartz; F: total feldspar; R: total lithic fragments (after Folk et al., 1970).Photomicrographs A and B show detrital composition of Whicher Range sandstones. A: Sandstone with subangular to subrounded quartz, feldspar (with cleavage and/or twinning) and minor grains such as garnet $(\mathrm{G})$ and replacement of a primary grain by calcite (c). B) Sandstone with quartz and feldspar grains and detrital biotite flakes (brown to dark).

Table 2: A summary of textural and sedimentary characteristics, diagenetic features and poroperm values of Willespie Formation in the Whicher Range field.

\begin{tabular}{|c|l|}
\hline $\begin{array}{c}\text { Sedimentary and } \\
\text { diagenetic features }\end{array}$ & \multicolumn{1}{c|}{ Description } \\
\hline Lithology & Feldspathic sandstone, siltstone, shale, coaly shale, coal \\
\hline Grain size & Fine to coarse-grained and in some cases gravelly sandstone \\
\hline Sorting & Weak to moderate (in fine-grained sandstones is well) \\
\hline Roundness & Mostly subrounded to subangular \\
\hline $\begin{array}{c}\text { Textural and } \\
\text { mineralogical maturity }\end{array}$ & Immature to submature \\
\hline Diagenetic features & Compaction (mostly physical), cementation, dissolution, replacement \\
\hline Cement type & Authigenic clays, calcite, silica \\
\hline Pore type & $\begin{array}{l}\text { Isolated dissolution pores, microporosity in clay minerals, minor } \\
\text { primary intergranular pores }\end{array}$ \\
\hline Porosity $(\%)$ & \multicolumn{2}{c}{$5-16 \%$} \\
\hline Permeability $(\mathbf{m D})$ & \multicolumn{2}{c}{$<0.1$ to $>1 \mathrm{mD}$} \\
\hline
\end{tabular}




\section{Reservoir properties}

Investigation of the Willespie Formation from reservoir quality point of view indicates that pore system properties of the reservoir sandstones show intimate relationship with their primary depositional characteristics, mineralogy and diagenesis. These parameters are described as follows.

\subsection{Depositional characteristics}

Changes in depositional environments have been proved to be a control in reservoir properties (Weber, 1980). In a comparison between the reservoir sandstone facies with their core porosity and permeability data, Orsini and Rezaee (2012) demonstrated that low reservoir quality is mostly related to floodplain (FP), crevasse splays (CS) and channel margins $(\mathrm{MCH})$ whereas better qualities are associated with channel $(\mathrm{CH})$ and crevasse channel facies ( $\mathrm{CSCH}$ ) (Fig. 4). Overall, intervals of lower reservoir quality seem to relate to the more argillaceous facies which is more likely to be controlled by the depositional environment. In addition, according to the core poroperm cross plot of reservoir sandstones, shown in Figure 5, there is generally a meaningful relationship between grain size and reservoir properties of the facies; the larger grain size, the reservoir quality is higher. This means initial depositional facies and texture play an important role on controlling the pore system properties of tight sandstones and reservoir heterogeneity in the field.

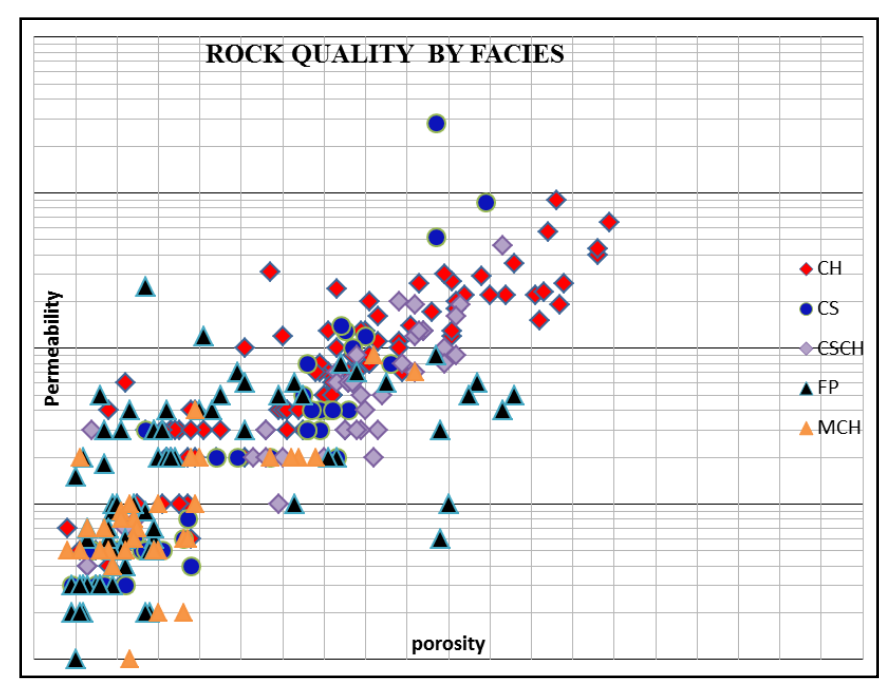

Fig. 4: Porosity and permeability plot for different facies in Whicher Range field (after Orsini and Rezaee, 2012). 


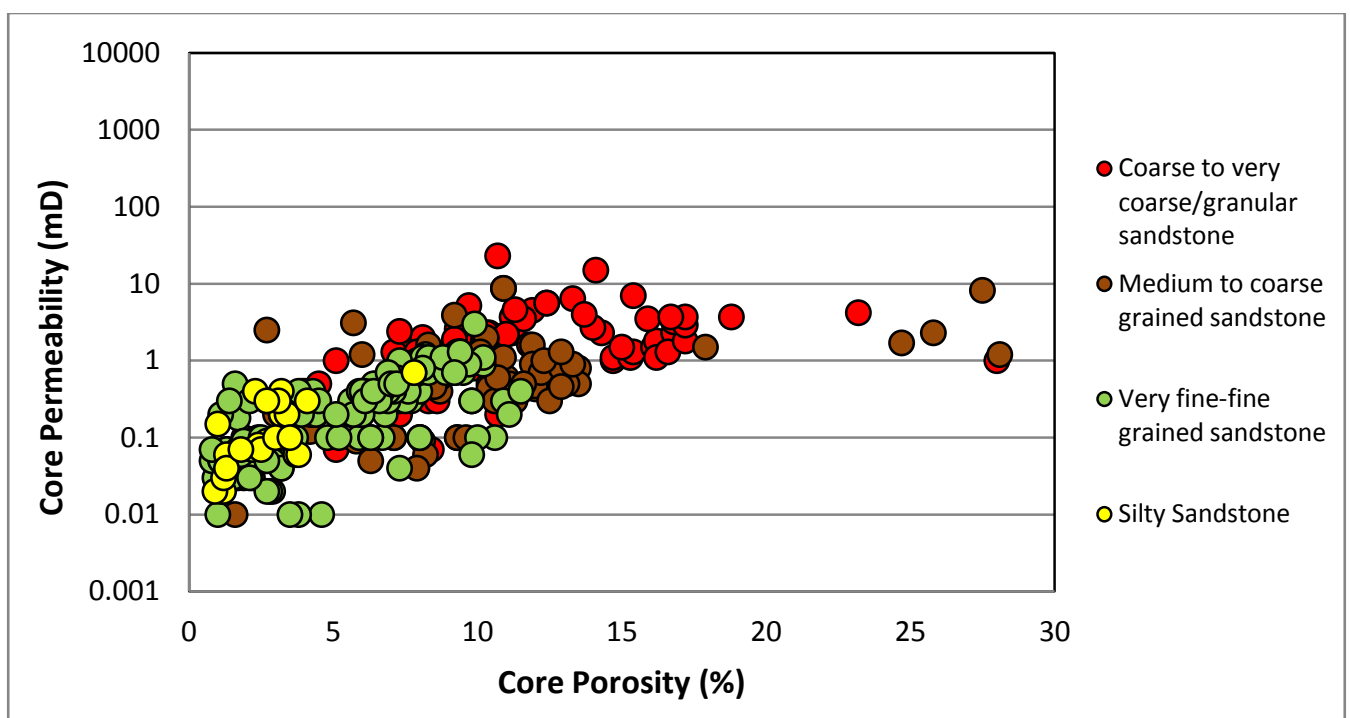

Fig. 5: Core poroperm cross plot for reservoir sandstones of the field based on their grain size.

\subsection{Diagenesis and mineralogy}

Diagenesis has the main control on pore system properties of reservoir sandstones in the field. In fact, sandstone facies of the Whicher Range field under the effect of diagenetic processes are characterized by a compacted and cemented fabric with low to high porosity and especially low permeability, as they are considered tight. Compaction mainly as mechanical at the first stages of diagenesis, and cementation by quartz, calcite and clay minerals at the next stages are the main diagenetic overprints affecting the pore system properties of the sandstones. In comparison, dissolution as an improving diagenetic agent of reservoir quality, is not widespread and the dissolution vugs are mostly isolated and non-effective. Figure 6, schematically shows the integrated effect of different diagenetic processes and their impact on tightness nature of the reservoir sandstones.

SEM photomicrographs of diagenetic features within the reservoir are shown in Figure 7.These facies show some similarity in diagenetic features (e.g., cementation by silica and clay minerals) with tight reservoir sandstones in other basins such as Ordos Basin of China (Yang et al., 2008; Zhang et al., 2009), Piceance Basin of Colorado (Stroker et al., 2013) and the Greater Green River Basin of Wyoming (Tobin et al., 2010). In addition to initial sedimentary texture (grain size), one factor which also controls the effect of diagenesis within the 
reservoir is the mineralogical composition of sandstone facies that is attributed to

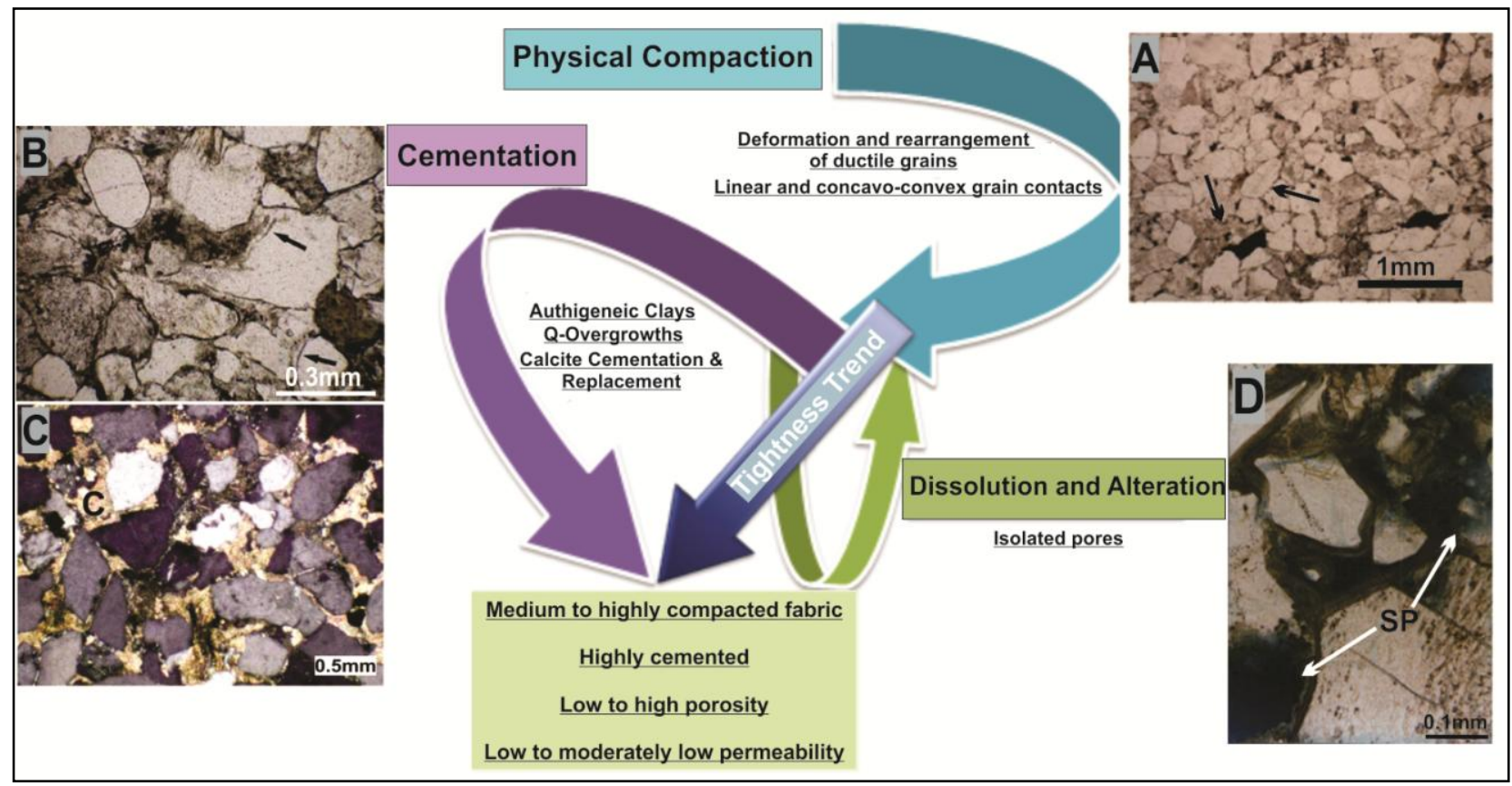
micas and rock fragments. These components, in fact, have provided and accelerated the condition for acting of compaction, alteration and dissolution within the reservoir that has been resulted in modification of pore system properties and increasing of internal reservoir heterogeneity. Figure 8 (A and B) shows how the compaction has differently acted on two sandstone facies of the reservoir. According to this figure, sandstone facies A due to the fine-grained texture and also the presence of ductile grains (mica) has been more compacted than medium to coarse-grained facies B.

Fig. 6: A schematic picture showing the integration effects of compaction, cementation and dissolution on tightness nature of reservoir sandstones in the Whicher Range field. Cementation by clay minerals, silica (B) and calcite (C) in association with physical compaction (A) has the main effect on decreasing the reservoir quality and creation a compacted and cemented fabric of reservoir sandstones. Arrows in photomicrograph A show the effect of physical compaction in grain contact boundaries, and in photomicrograph $\mathrm{B}$, overgrowth quartz cement, and in photomicrograph $\mathrm{D}$, they show secondary pores (SP) from dissolution. 

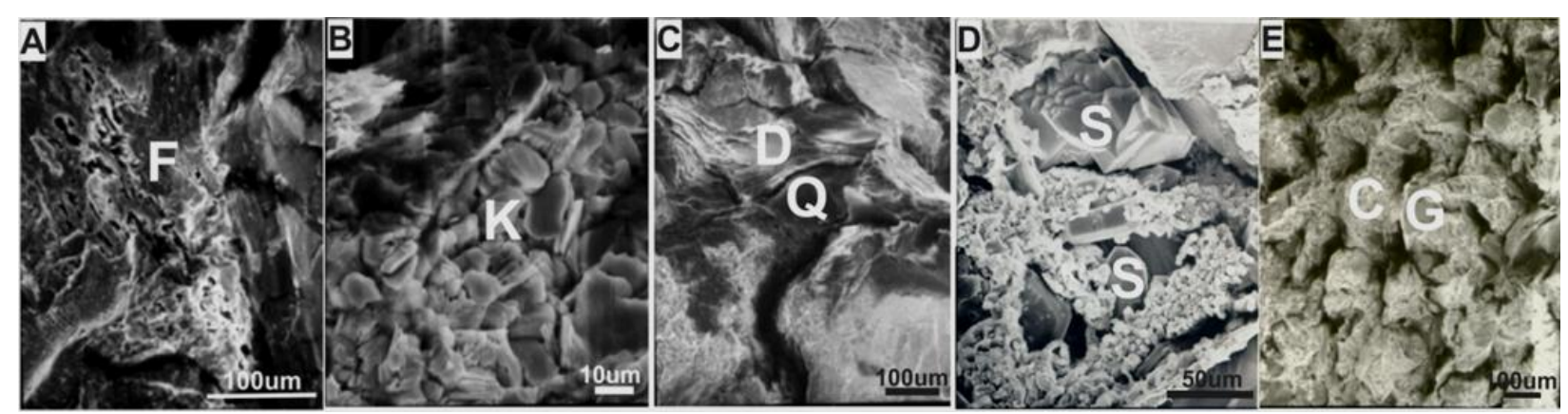

Fig. 7: SEM photomicrographs of diagenetic features within the reservoir sandstones. A) Partially dissolution of feldspar grain $(\mathrm{F})$ is associated with the formation of small secondary pores. B) Kaolinite booklets as pore-filling clay cement. C) A grain (D) which has been undergone ductile deformation between quartz grains (Q). D) Pores have been partially occluded by silica overgrowths (s) and by the growth of authigenic clays (kaolinite and smectite). E) Detrital grains $(G)$ have been surrounded by clay $(C)$.

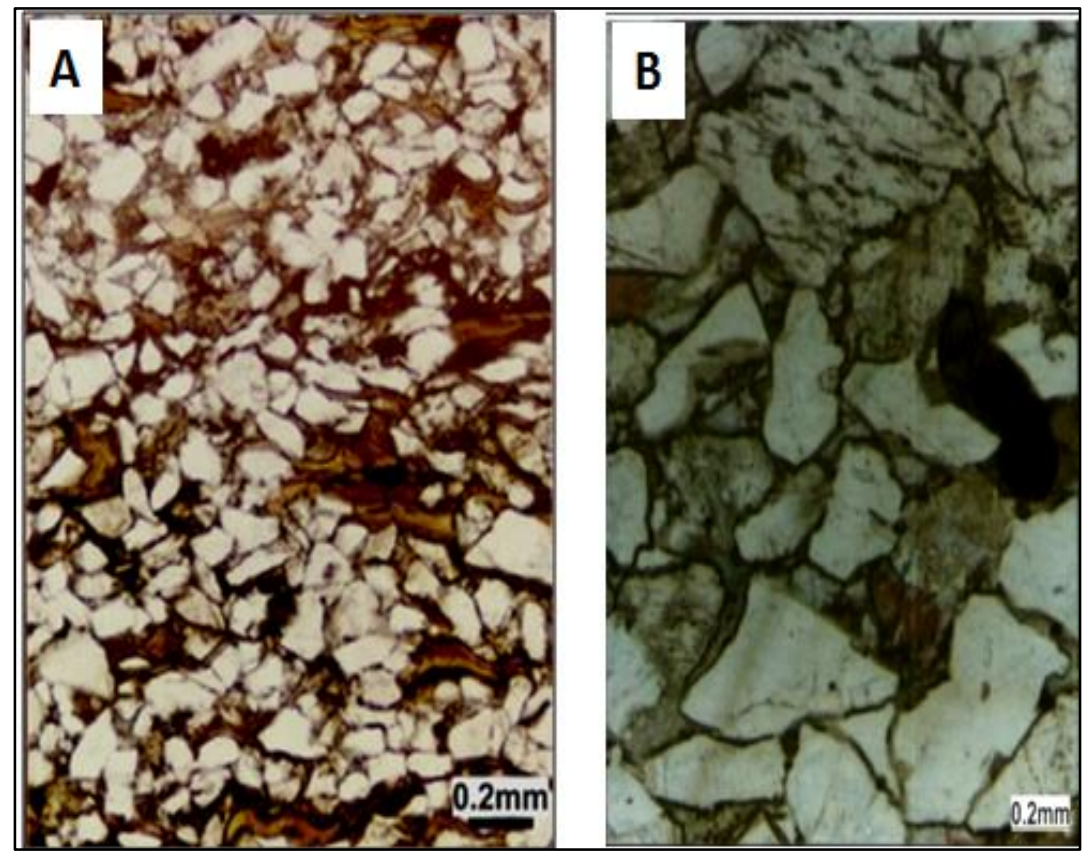

Fig. 8: Different effect of compaction on two sandstone facies of the Whicher Range field. A: fine-grained facies with ductile grains between quartz grains. B: medium to coarse-grained sandstone facies. 


\section{Geocellular modeling}

In this stage, after gaining an understanding of depositional facies and environments and diagenetic features of the reservoir sandstones, work for building a 3D model showing the distribution of facies and petrophysical characteristics in the field was started. Accordingly, all relevant data derived from wells including core, well log, wellhead, well top in association with structure map for the top of the formation and fault data were loaded into the geological model database. Afterwards, reservoir modeling, according to the workflow shown in Figure9, was accomplished. The stages are briefly described as follows.

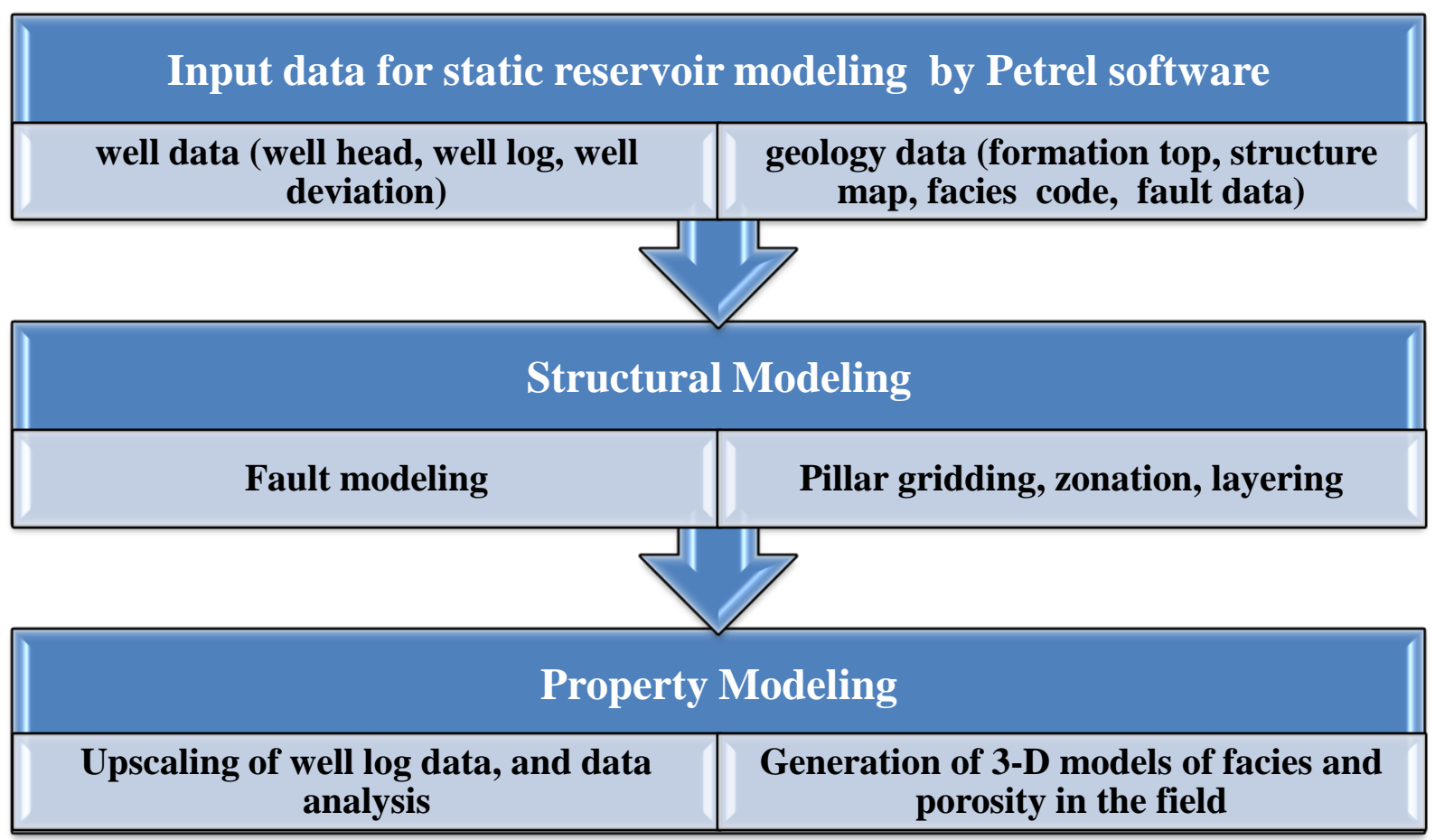

299 Fig.9: Workflow for geocellular modeling of the Willespie Formation in the Whicher Range 300 gasfield.

302 6.1. Structural Modeling

Anticline structure of the Whicher Range field, as mentioned above, has been affected by tectonic movements and the resultant faulting. Such faults have an important role on reservoir compartmentalization, and they are predominantly NNE-SSW oriented with an average trend of $010^{\circ} \mathrm{N}$. This trend aligns well with 
the structural trend of the Bunbury Through (Ciftci, 2012). Data for these faults were loaded into the geological model database to constitute the fault surfaces within the 3D model (Fig.10). Afterwards, the reservoir volume was gridded by cells with certain dimensions.

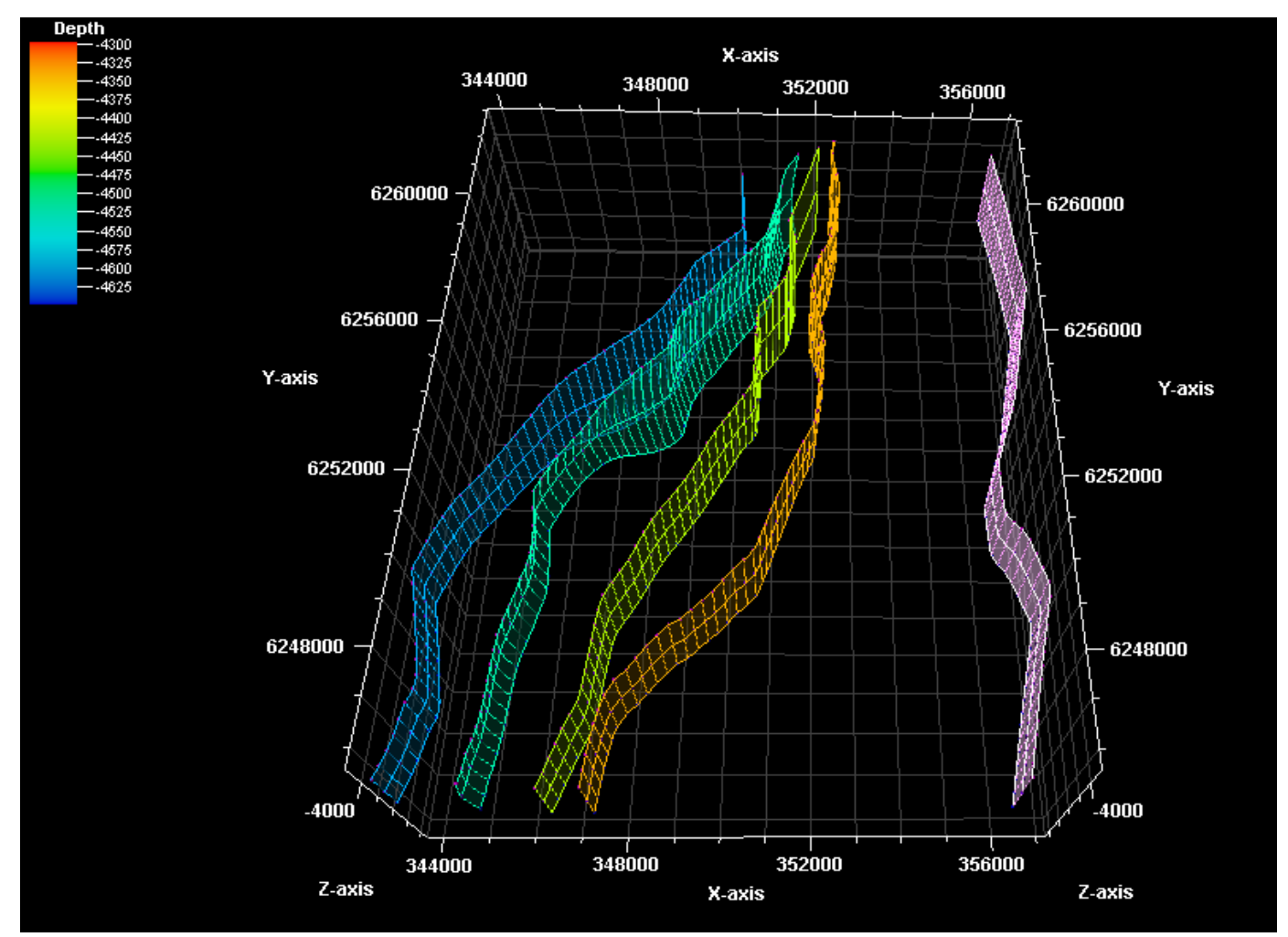

322 Fig.10: The position of faults with NNE-SSW trend used in reservoir modeling of the Whicher 323 Range field.

324 The Willespie Formation in the Whicher Range field due to the alternation and 325 overlapping of various units of sandstone, siltstone, shaleand coal shows a high 326 lateral and vertical heterogeneity in lithology. Therefore, the reservoir interval 327 based on the main sandstone packages is classified into numerous reservoir 328 intervals, named as Latin letters (A, B, C..., W), in a descending order. Sandy 329 packages which are correlatable between the wells, in fact, are identified based on 330 DST and production flow test information provided by Pennzoil Far East Company 331 (1998), and considered as reservoir units throughout the well interval. Also, non332 reservoir shaly and silty intervals between them were named as sub-letters (i.e., 333 A2, B2, C2 ...) in this study (Fig.11).In geocellular modeling of the Whicher 334 Range sandstones, the interpreted structure map for the top of the Willespie 
5335 Formation was used as a base surface (Fig. 12). Afterwards, based on such a map, 6336 the surfaces for the different zones within the reservoir were determined. Then,

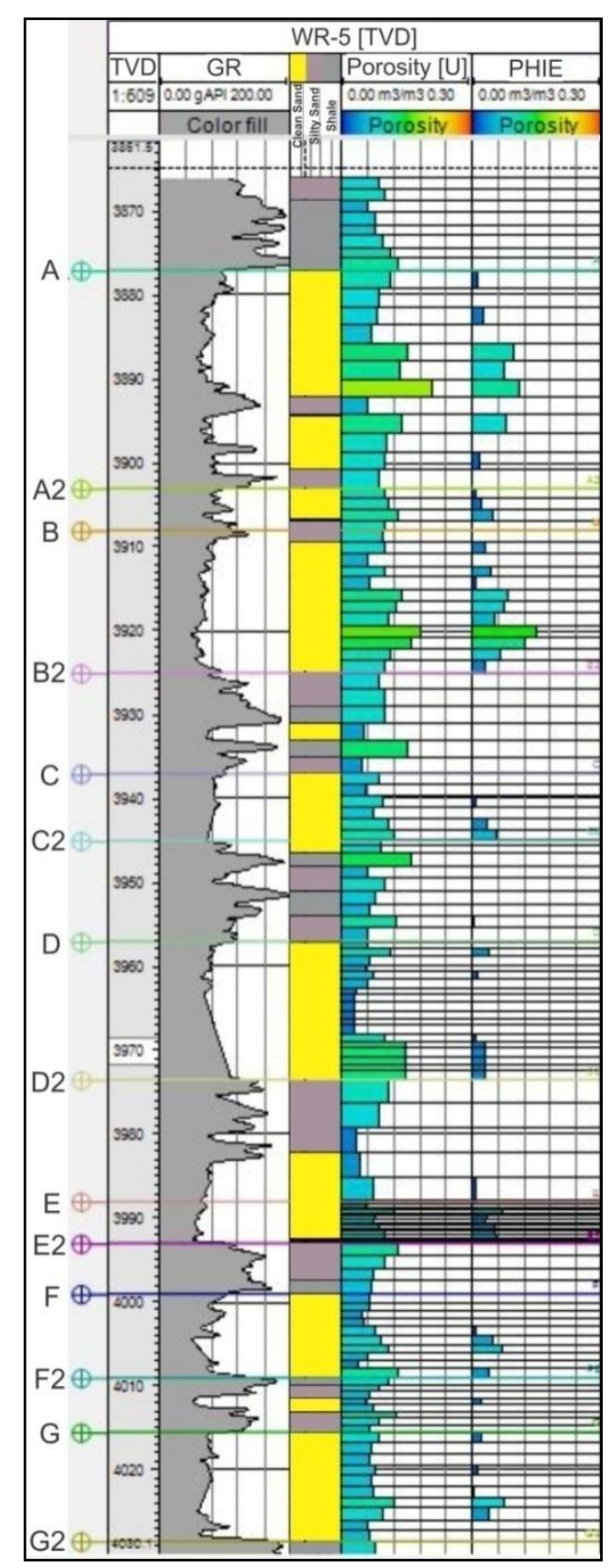

356 Fig. 11: Subdivision of the Willespie reservoir, in one of the wells (WR5) of the Whicher Range 357 Field, into various intervals (named as Latin letters) based on the main sandstone units which are 358 correlatable between the wells in the field. 


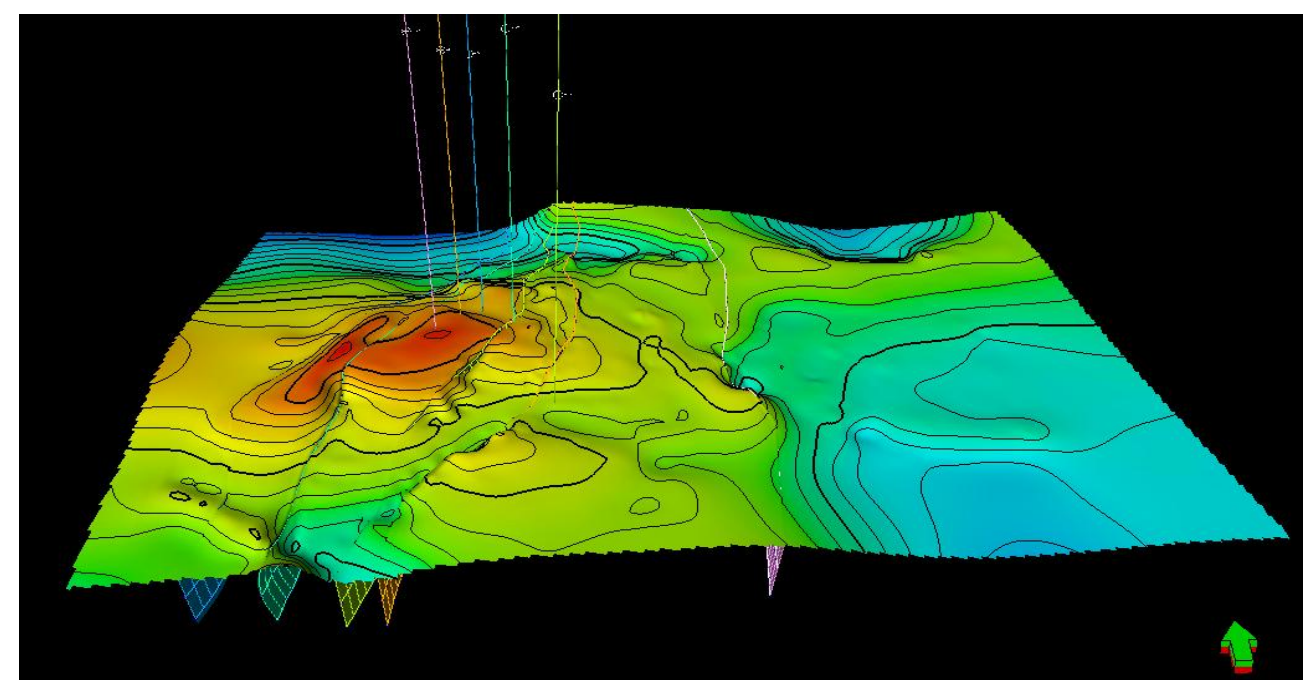

Fig.12: Structur map for the top of the Willespie Formation in the Whicher Range field.

\section{6.2. Property Modeling}

369 After structural modeling and establishing the initial reservoir skeleton, facies and 370 petrophysical characteristics of the reservoir sandstones based on the available data 371 from five wells were modeled to investigate their distribution in the field. 372 Variations in reservoir characteristics between the studied wells and throughout the 373 field can be modeled using statistical methods. Three main steps for property 374 modeling are described in below.

\section{$375 \quad 6.2 .1$. Scale-up}

376 Propagating the reservoir properties within the grid cells is done by which each cell 377 has a certain value for a specific parameter. But the grid cells often are much larger 378 than the sample density for that parameter, and the parameter values within the 379 cells must be scaled up before they can be entered into the grid. In this study, 380 "most of" approach has been applied for scaling up of facies. It was tried to 381 maintain the primary distribution function of well data. Histogram in Figure 13 382 demonstrates the upscaled result for facies in comparison with the original log. In 383 addition, for porosity upscaling which has been accomplished based on the 384 "Arithmetic" method, validation histogram is shown in Figure 14. 
1

4

387

388

389

390

391

392

393

394

23

$24 \quad 395$

26

27

28

29

30

31

32

33

34400

35

36

37

38

39

40

41403

42

$43 \quad 404$

44

45

46

47

48

49

$50 \quad 407$

51

52

53

54

55

56

57410

$\begin{array}{ll}58 & 411\end{array}$

59

60

61

62

63

64

65

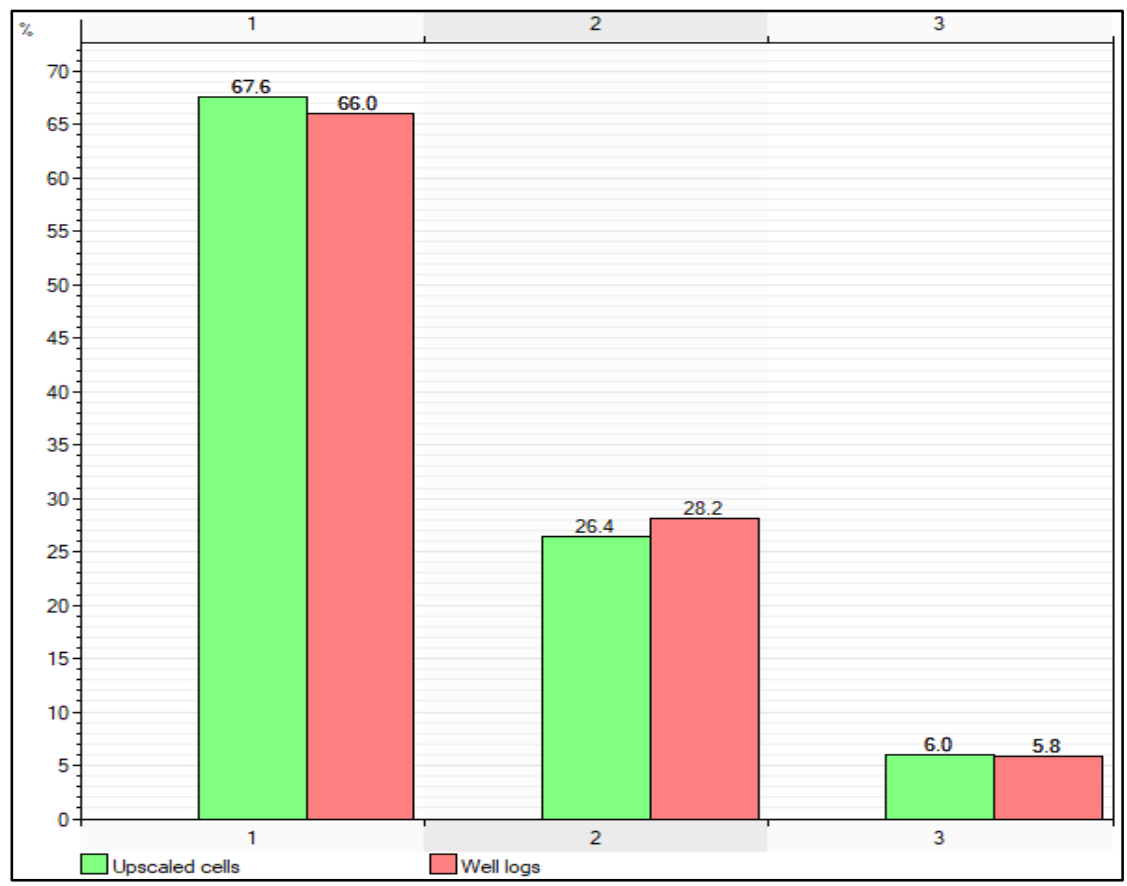

Fig. 13: Validation histogram showing the scaled up results for reservoir facies in comparison with the original well logs (numbers in x-axis are different facies: 1-clean sands, 2-silty sandstones, and 3-shale).

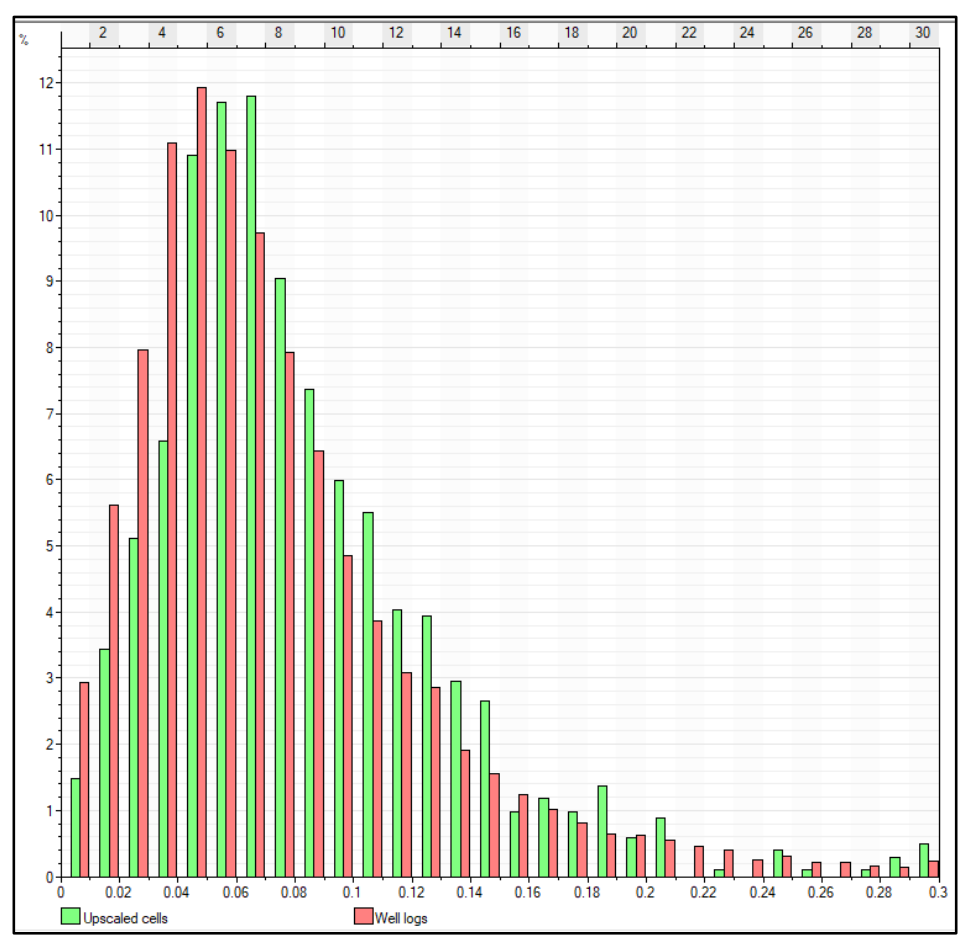

Fig. 14: Validation histogram showing the scaled up result for porosity in comparison with the original well $\log$. 
Data analysis process, as an important step in reservoir modeling, is used in controlling of data quality, investigation of their trend, and preparing the input data for facies and petrophysical modeling. In this study, variation trend of data in reservoir sandstones between the wells for each zone was investigated individually, by variogram analysis in three directions ( $\mathrm{x}$, yand $\mathrm{z}$ ). The main direction used in modeling was determined by variogram map derived from acoustic impedance (Fig. 15). In a variogram map, the direction of contour lines with the least variation or variance (east/northeast-west/south-west in this study) shows the most continuity of data in that direction which can be considered as the main direction of the variogram. Figure 16 shows examples of the variograms used for porosity modeling in three vertical, major and minor directions, in one of the reservoir zones.

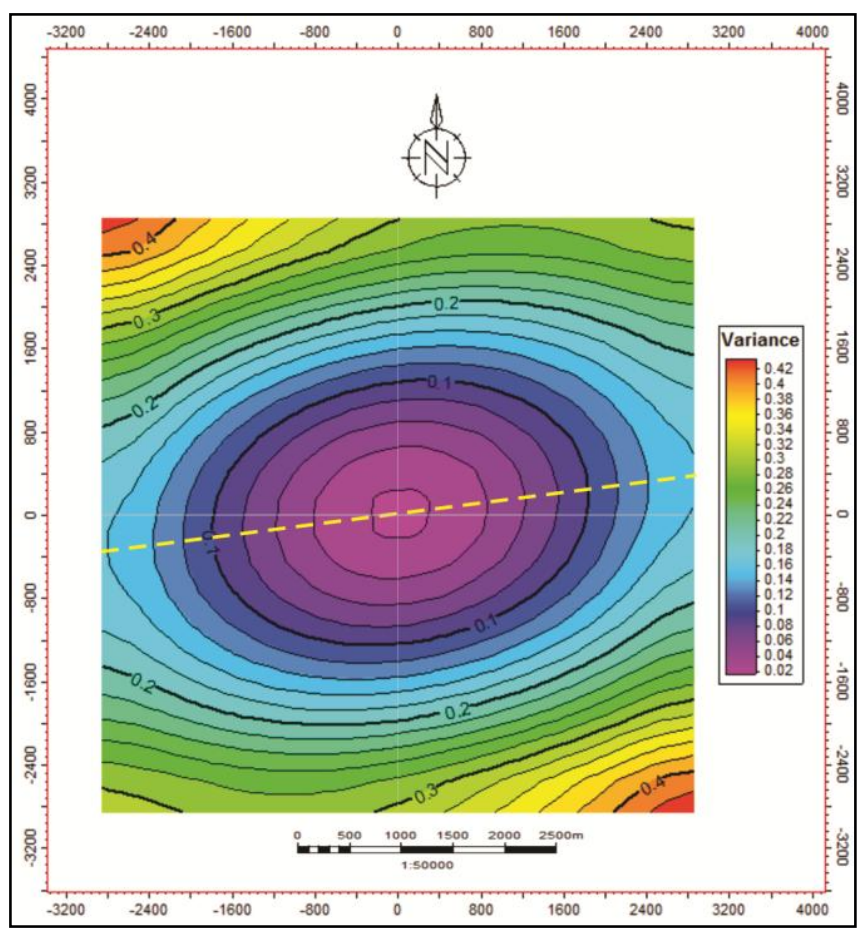

Fig. 15: Variogram map derived from acoustic impedance which is used to determine the main direction of variogram for modeling of reservoir sandstones in the studied field. 


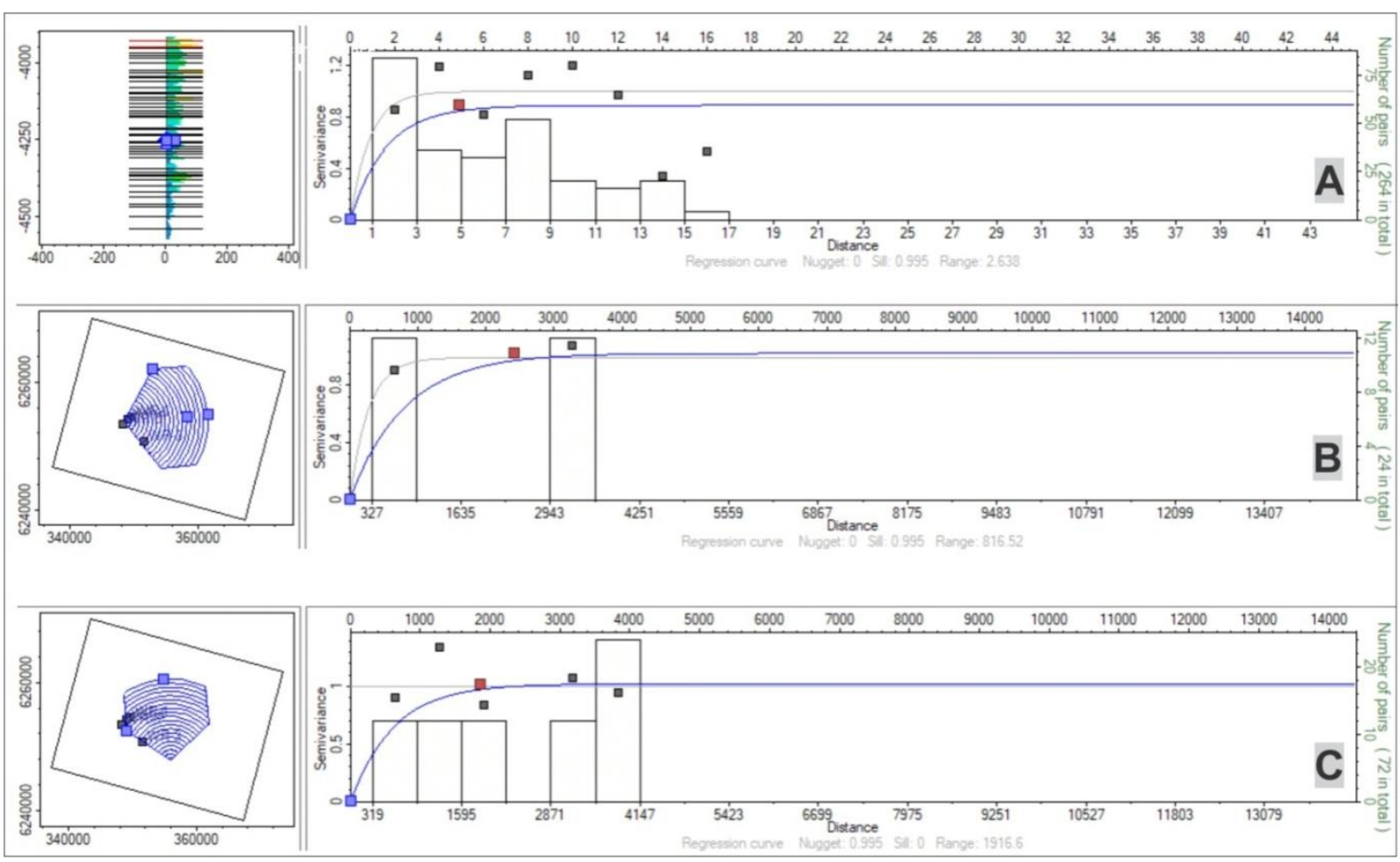

Fig. 16: Examples of the variograms in three vertical (A), major (B) and minor (C) directions used for porosity modeling in one of the reservoir units (zone A) of the Willespie Formation.

6.2.3. Modeling based on a suitable algorithm

In this study, reservoir modeling was constructed based on stochastic methods. In addition, according to the literature, stochastic methods produce more realistic results of reservoir properties comparing them to deterministic methods such as Kriging for which only one solution is generated.

\subsubsection{Facies modeling}

Spatial and geometrical distribution of facies is considered as an important agent of heterogeneity in clastic reservoirs (Yao and Chopra, 2000). So, facies modeling is the main stage in reservoir characterization and modeling of these reservoirs (Deutsch, 2002).Among different methods used in modeling of reservoir facies, Object-based and Pixel-based algorithms are two main methods. The most common Pixel-based algorithm is Sequential Indicator Simulation. This method is conditioned by variogram models that show the size and spatial distribution of 452 facies patterns. Three groups of depositional facies in the Whicher Range field are 453 coarse grained and clean sandstones $(\mathrm{GR}<80)$ of fluvial channel $(\mathrm{FA}-1)$ and 
crevasse splay (FA-3) as the main reservoir units, fine-grained and silty sandstones $(80<\mathrm{GR}<130)$ related to channel margin $(\mathrm{FA}-2)$ and crevasse splay (FA-3), and silty/shaly units (GR>130) of flood plain (FA-4) and paludal deposits (FA-5). A 457 specific digital code was assigned to each facies group for loading into the model 458 database. Data analysis was accomplished by their interpolation with a suitable 459 variogram model (spherical) in three spatial directions. Afterwards, facies model 460 using well data information and based on the Sequential Indicator Simulation was 461 extracted (Fig.17). According to the facies model, clean sandstone facies which 462 constitute the main reservoir units are interlayered with silty sandstones and shales, 463 and they show a significant change in thickness and their lateral and vertical 464 continuity throughout the reservoir interval.

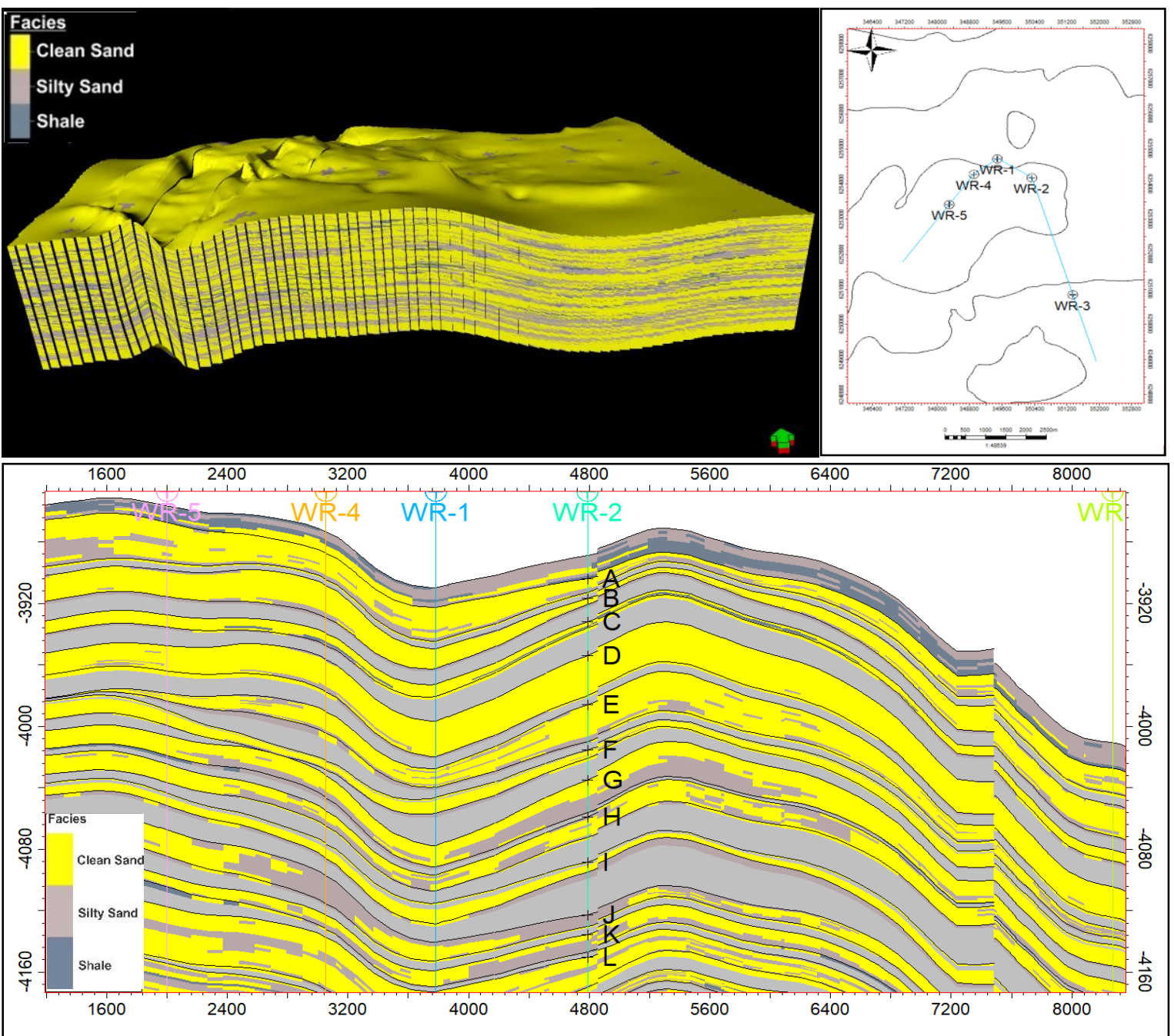

Fig. 17: 3D facies model and its cross-section along the wells of the Whicher Range field showing the distribution of reservoir facies (clean sand, silty sand and shale) in the field. 


\subsubsection{Porosity modeling}

Porosity model of reservoir sandstones in the Whicher Range field was created using Sequential Gaussian Simulation algorithm. Due to the clear and inverse relationship between the acoustic impedance (AI) and porosity (Fig. 18), it was used as the key control for modeling of porosity attribute. A model-based inversion approach was used to invert seismic data to acoustic impedance volume. After extraction of an optimal wavelet, AI was calculated through a deconvolution process. According to 3D view of acoustic impedance in Figure 19, this parameter generally shows a decreasing trend towards the upper part of the reservoir interval. Variation in AI can be interpreted based on depositional, diagenetic and petrophysical characteristics of the reservoir sandstones. As medium to coarse and very coarse sandstone facies with high porosity (10\% in average) are characterized by low values of AI, whereas fine to medium grained sandstones with low porosity (5\% in average) have high values of this parameter (Kadkhodaie-Ilkhchi et al., 2014). Accordingly, the co-kriging method was used to integrate the porosity and acoustic impedance data for reservoir modeling. In fact, co-kriging is a multivariate estimation method by which the spatial relationship between the primary (porosity) and secondary (AI) variables is analyzed, and the secondary variable is utilized in estimation to compensate the deficiency of primary variable.

Porosity was considered as the total and effective and it was analyzed by spherical variogram in three spatial directions. The extracted $3 \mathrm{D}$ models of total and effective porosity were shown in Figure 20 and Figure 21, respectively. According to the constructed models, total porosity shows significant increase towards the top of the formation. Such a result indicates porous zones have been concentrated in the upper parts of the reservoir. Although, effective porosity follows the same trend of total porosity, it has a sparse distribution within the reservoir interval. This is attributed to the effect of diagenetic processes (e.g., compaction, cementation and dissolution) on pore system properties, which is consistent with the tight nature of reservoir sandstones. It can be concluded that the initial sedimentary characteristics control the large-scale variations in reservoir properties including total porosity, and also the distribution of reservoir zones in the field. In contrast, diagenesis has the main control on effective porosity and internal reservoir heterogeneity. 
515

516

8

9

10

11

12

13

14

15

16

$17 \quad 520$

18

19

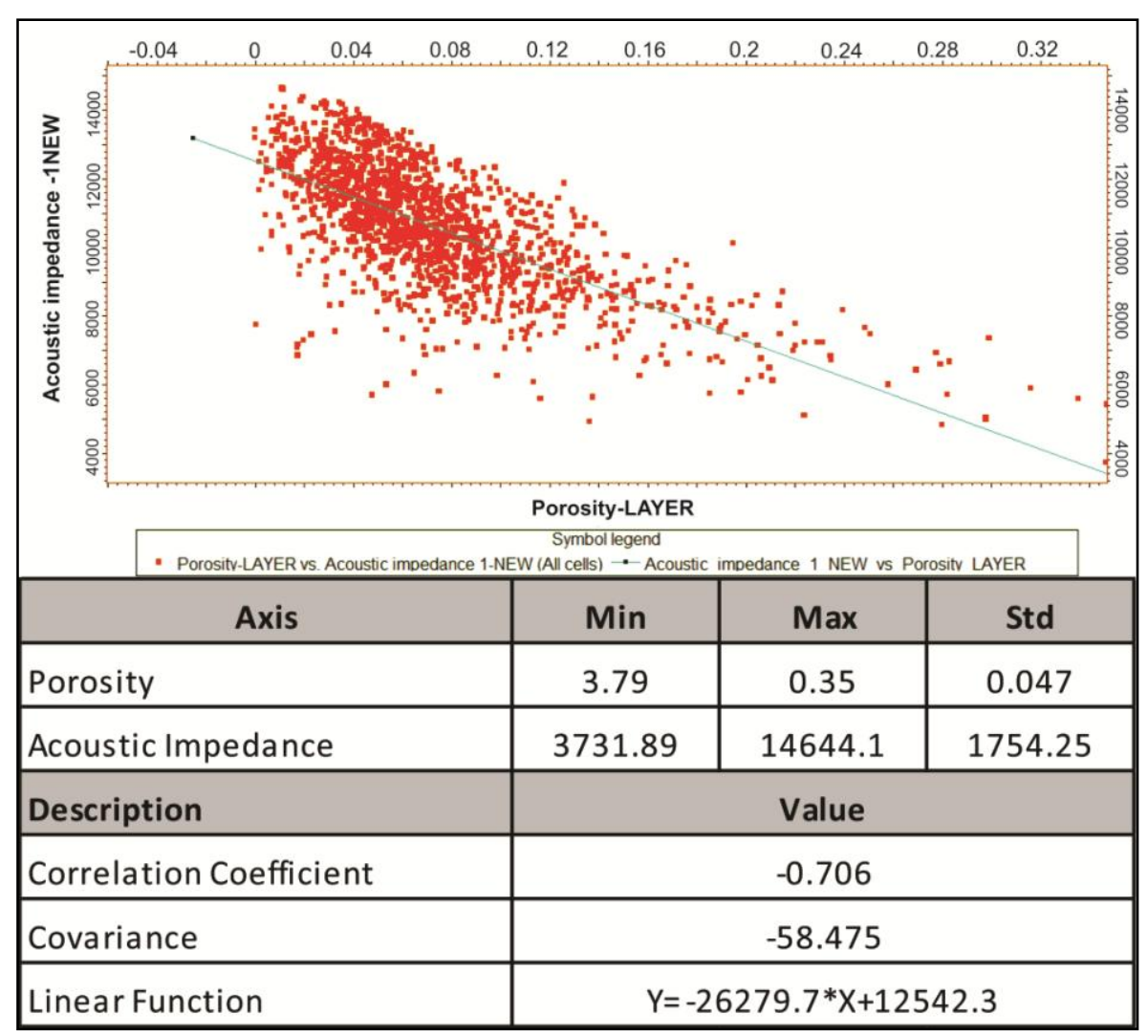

527 Fig. 18: Inverse relationship between acoustic impedance and porosity of reservoir sandstones in 528 the Whicher Range field. 
2

3

4540

541

8

9542

10

11

12

13

14

15

16

17

$18 \quad 546$

19

20

21

22

23

24

$25 \quad 549$

26

$27 \quad 550$

28

29

30

31

32

33

34553

35

36

37

38

39

40

41556

42

43

44

45

46

47

561

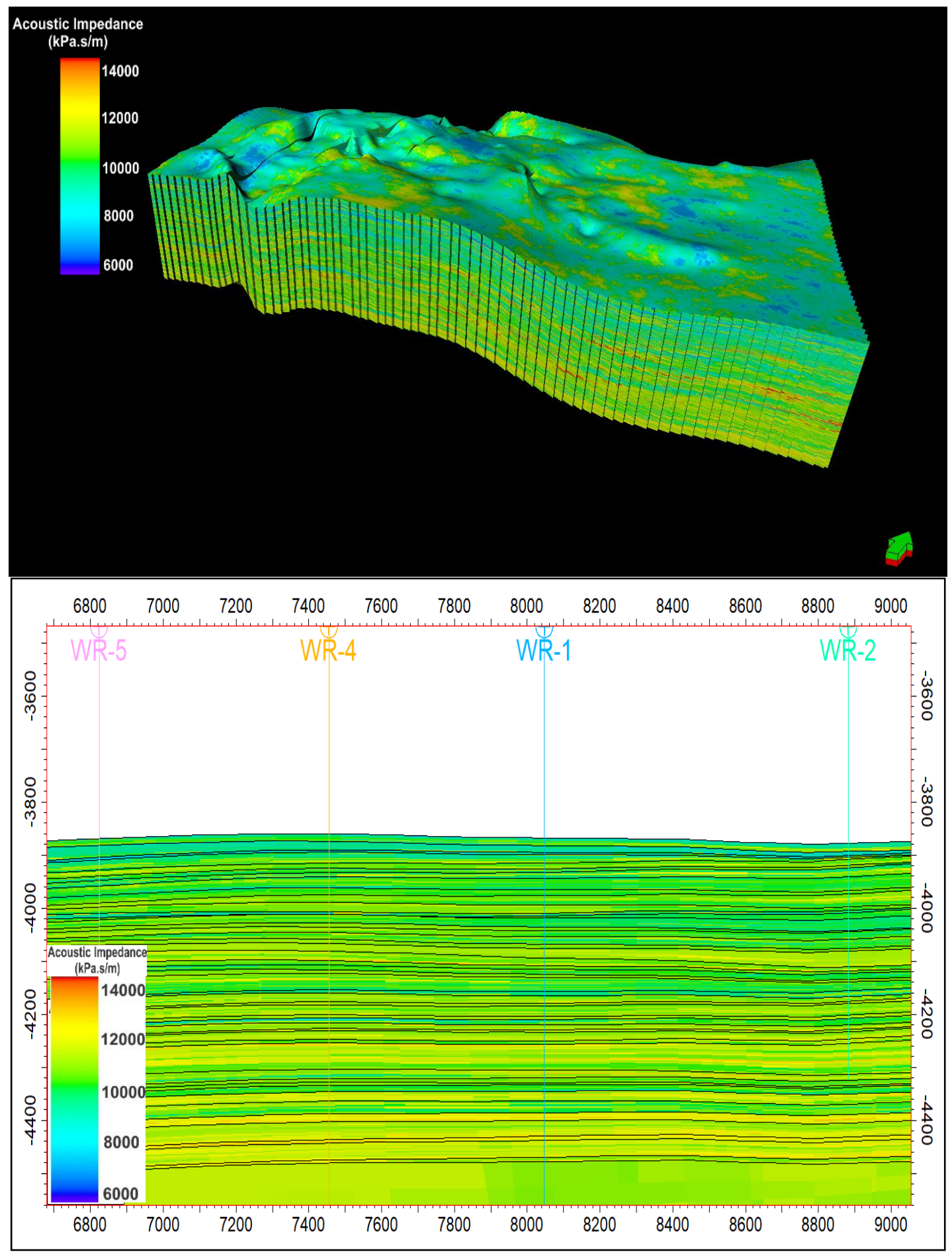

562 Fig. 19: 3-D view of acoustic impedance and its cross section along the Whicher Range wells shows a decreasing trend towards the upper part of the reservoir interval. 


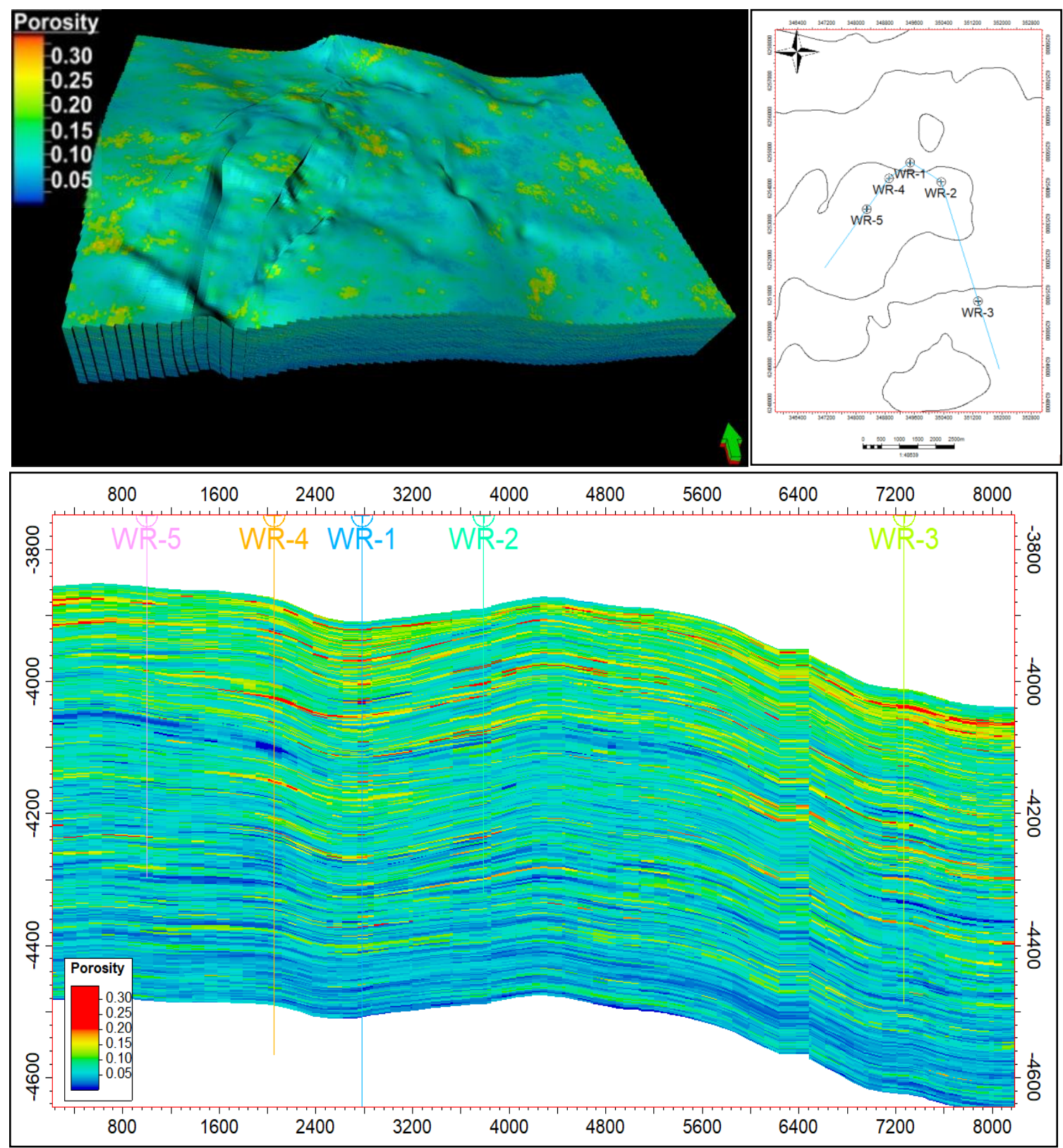

564

565 Fig. 20: 3D model of porosity and its cross section showing the distribution of total porosity in 566 the studied field. The general increasing trend of total porosity towards the upper parts of the 567 reservoir interval can be attributed to the accumulation of more porous and coarse grained 568 sandstone facies of fluvial channels in these parts of the reservoir. 

596

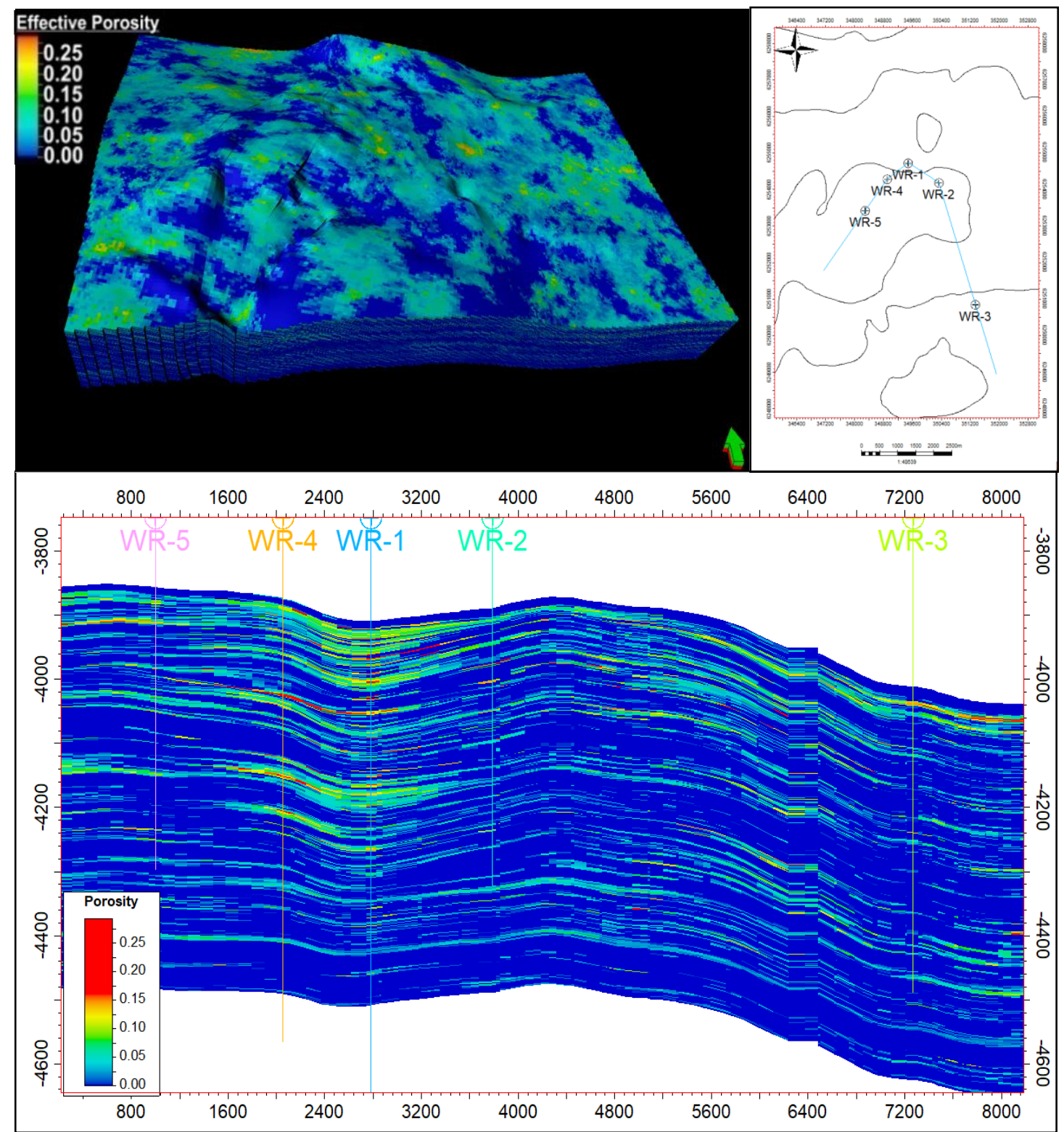

Fig. 21: 3D model of porosity and its cross section showing the distribution of effective porosity in the studied field. Increasing trend in effective porosity towards the upper parts of the reservoir interval is not clear as observed in total porosity trend. In addition, lateral increase of this parameter towards WR1 and WR4 wells is consistent with concentration of high porous and high permeable reservoir sandstones in their interval. 


\section{Results and discussion}

The results from facies and diagenesis analysis of tight sandstone facies and their effects on pore system properties indicate the complex effect of these parameters on reservoir heterogeneity reflecting in variability of reservoir properties throughout the field. High energy and coarse grained sandstone facies of the reservoir interval related to channel (FA-1) and crevasse splay (FA-3) subenvironments of meandering fluvial system contribute to main reservoir units with high reservoir quality in the field (Figs. $4 \& 5$ ).In contrast, fine grained and silty sandstone facies and coaly-slity shale interlayers of channel margin and flood plain sub-environments (FA-2, FA-4 and FA-5) under the effect of their initial depositional texture and also diagenesis are characterized by low reservoir quality, and have the potential to create barriers and baffles within the reservoir interval. In fact, variation in depositional environment of sandstone facies indicating by development of different facies association of specific sedimentary texture and structures has provided the main framework for development of reservoir zones in the field, and is considered as the main controlling factor on reservoir heterogeneity in the field scale. On the other hand, diagenesis by modification of primary depositional texture, composition and pore system properties has imported its effect on internal reservoir heterogeneity. According to the results from reservoir modeling in this study, most porous zones are coincident with coarse and high energy sandstone facies of fluvial channels that have been distributed as an individual or a set of stacked channels at the upper part of the formation (Figs. 17and 20). Although porosity shows a general increasing trend towards the upper sandstone units of the reservoir interval in five drilled wells of the Whicher Range field, this trend is not necessarily consistent with their thickness in the field (Fig. 22). This can also be seen in cross plot of Figure 23, where there is no clear relationship between porosity and thickness of sandstone units of the reservoir interval. This is attributed to heterolithic lithology of sandstone units, varying from very coarse to very fine and silty in size, and also the effect of diagenesis on pore system properties of the reservoir sandstones. Table 3 shows quantitative values of porosity and thickness of sandstone units as well as sand to shale thickness ratio in five wells of the field. Investigation of the reservoir facies along the Whicher Range wells, based on the porosity models, especially related to effective porosity (Figure 21) and also a 3D model of shale in the field (Fig. 24), indicates WR1 and 
WR4 wells have more porous and thicker zones than the other wells in their interval. This is consistent with the results from production tests and the results from previous studies (e.g., Kadkhodaie-Ilkhchi et al., 2013) mentioning high production and most promising sandstone zones in these wells. Also, thickness map of reservoir sandstones shows a decrease of the sand contribution towards the south-east parts of the field where WR2 and WR3 are situated (Fig. 25). This is also approved by an increase of sand to shale thickness ratio from WR2 and WR3 wells towards WR1, WR4 and WR5 wells. Fence diagrams of facies and porosity models of the reservoir sandstones are shown in Figure 26.

642 Faulted and anticlinal structure of the Whicher Range field, as mentioned early, is 643 related to tectonic and evolution history of the Perth Basin. According to Lasky et al (1993), the seismic data indicates that the Permian sequence thickens eastwards towards the Darling Fault and suggests that the fault controlled sedimentation during that time. Therefore, pore system of deeply buried $(\sim 4 \mathrm{~km})$ sandstone facies of the Willespie Formation have been initially affected by the basin subsidence along faults, as they are characterized by a compacted fabric. However, the effect of faulting on compartmentalization of the reservoir is not clear, and need investigation of more data and observation of reservoir data (production, pressure, etc.) and analysis of seismic sections of the field.

The uncertainty with the results derived from this work is not inevitable. As, the volume and particularly the quality of data available to construct the model, add a significant degree of uncertainty. However, the findings of this study provide a general view of the distribution of reservoir units and their porosity in the field which based on the horizontal drilling in upper parts of the reservoir interval especially in north-east section of the field is proposed. 


\begin{tabular}{|c|c|c|c|c|c|c|c|c|c|c|}
\hline \multirow{2}{*}{$\begin{array}{l}\text { Sand } \\
\text { Unit }\end{array}$} & \multicolumn{2}{|r|}{ WR1 } & \multicolumn{2}{|r|}{ WR2 } & \multicolumn{2}{|r|}{ WR3 } & \multicolumn{2}{|r|}{ WR4 } & \multicolumn{2}{|r|}{ WR5 } \\
\hline & $\begin{array}{l}\text { Phi } \\
(\%)\end{array}$ & Thickness(m) & $\begin{array}{l}\text { Phi } \\
(\%)\end{array}$ & Thickness(m) & $\begin{array}{l}\text { Phi } \\
(\%)\end{array}$ & Thickness(m) & $\begin{array}{l}\text { Phi } \\
(\%)\end{array}$ & Thickness(m) & $\begin{array}{l}\text { Phi } \\
(\%)\end{array}$ & Thickness(m) \\
\hline A & 12.97 & 22 & & 9 & 14.07 & 15 & 10.93 & 17 & 10.43 & 23 \\
\hline B & 12.29 & 13 & 5.59 & 4 & 10.63 & 20.5 & 11.03 & 21 & 11.31 & 17 \\
\hline C & 11.02 & 8 & 5.20 & 4 & 9.30 & 7 & 8.81 & 8 & 8.36 & 8 \\
\hline D & 12.03 & 23 & 9.62 & 25 & 9.19 & 20 & 9.08 & 21 & 6.87 & 16.5 \\
\hline $\mathbf{E}$ & 9.24 & 13 & 7.15 & 24 & 7.64 & 6 & 11.58 & 14 & 10.04 & 5 \\
\hline $\mathbf{F}$ & 14.03 & 10 & 7.06 & 5.5 & 9.52 & 13.5 & 15.98 & 6 & 6.51 & 10 \\
\hline G & 12.42 & 14 & 5.34 & 21.5 & 11.21 & 11.5 & 9.68 & 14.5 & 7.19 & 13 \\
\hline $\mathbf{H}$ & 7.42 & 10.5 & 10.69 & 13.5 & 8.15 & 11 & 10.16 & 10 & 10.13 & 12 \\
\hline $\mathbf{I}$ & 7.11 & 12 & 9.40 & 6.5 & 9.79 & 19.5 & 5.38 & 9.5 & 8.83 & 8 \\
\hline J & 10.02 & 12 & 7.96 & 7.5 & 12.81 & 10 & 4.71 & 18 & 5.84 & 17 \\
\hline $\mathbf{K}$ & 9.85 & 10 & 5.45 & 11.5 & 9.06 & 8 & 10.12 & 9 & 5.22 & 7 \\
\hline $\mathbf{L}$ & 9.97 & 38 & 7.06 & 19.5 & 6.63 & 10 & 9.01 & 34 & 6.89 & 34 \\
\hline $\mathbf{M}$ & 7.76 & 19 & 6.05 & 9 & 6.88 & 28 & 5.84 & 17 & 5.62 & 22 \\
\hline $\mathbf{N}$ & 5.15 & 21 & 6.44 & 22 & 4.30 & 15.5 & 9.55 & 19 & 5.72 & 20 \\
\hline 0 & 10.33 & 9 & 7.58 & 9 & 9.11 & 16 & 8.12 & 9 & 5.63 & 7 \\
\hline $\mathbf{P}$ & 5.06 & 6 & 5.67 & 4.5 & 6.39 & 12.5 & 6.86 & 4 & 6.92 & 4 \\
\hline $\mathbf{Q}$ & 9.91 & 12 & 8.45 & 9 & & 6 & 2.67 & 7 & 6.60 & 11 \\
\hline $\mathbf{R}$ & 6.11 & 10 & \multicolumn{2}{|c|}{ Sand/Shale: 1.12} & & 14.5 & 8.54 & 17 & \multicolumn{2}{|c|}{ Sand/Shale: 1.29} \\
\hline $\mathbf{S}$ & 9.22 & 3 & & & \multicolumn{2}{|c|}{ Sand/Shale: 1.16} & 6.96 & 5.5 & & \\
\hline $\mathbf{T}$ & 7.12 & 18.5 & & & & & 3.64 & 18 & & \\
\hline $\mathbf{U}$ & 4.04 & 15.5 & & & & & 5.31 & 15 & & \\
\hline V & 2.41 & 8.5 & & & & & 3.52 & 7 & & \\
\hline \multirow[t]{2}{*}{$\mathbf{W}$} & 3.20 & 10 & & & & & 5.85 & 6.5 & & \\
\hline & \multicolumn{2}{|c|}{ Sand/Shale: 1.22} & & & & & \multicolumn{2}{|c|}{ Sand/Shale: 1.30} & & \\
\hline
\end{tabular}




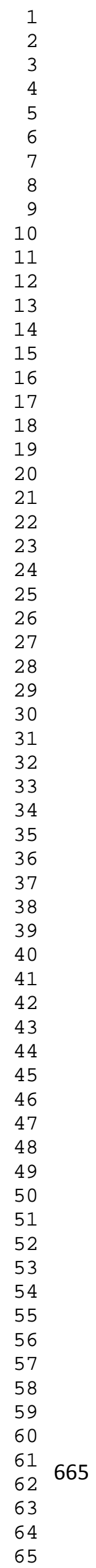

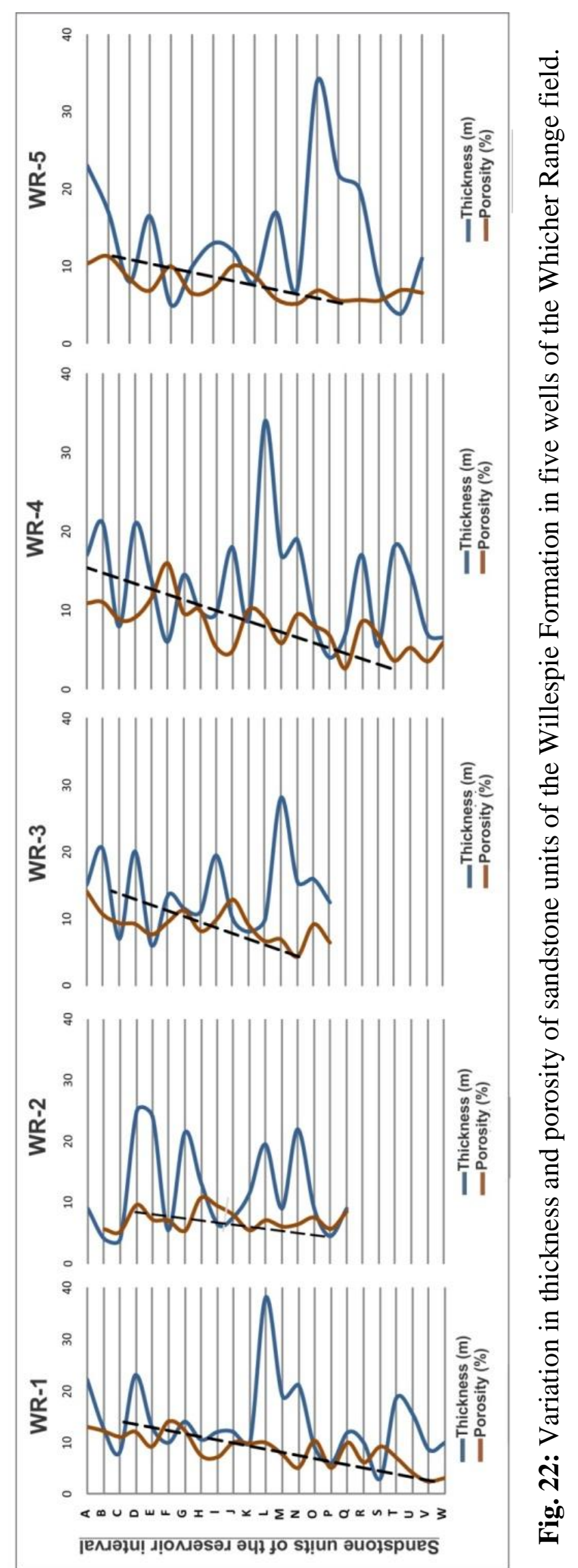




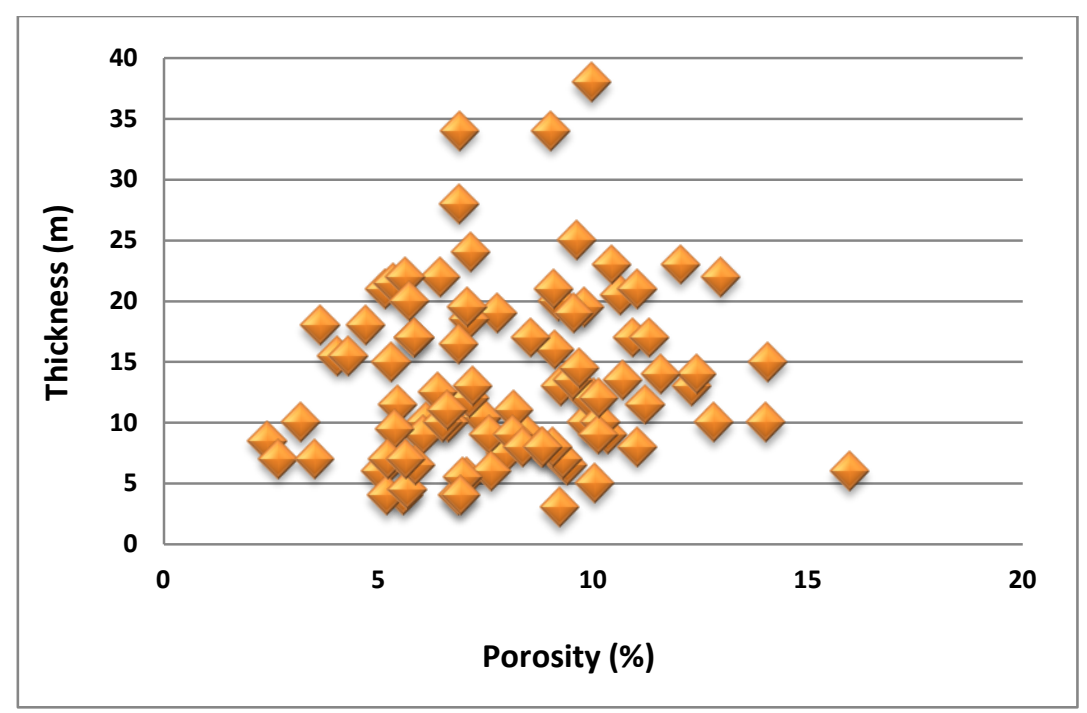

667 Fig. 23: Cross plot of porosity and thickness of sandstone units in the field. According to this 668 plot, there is no clear relationship between these parameters.
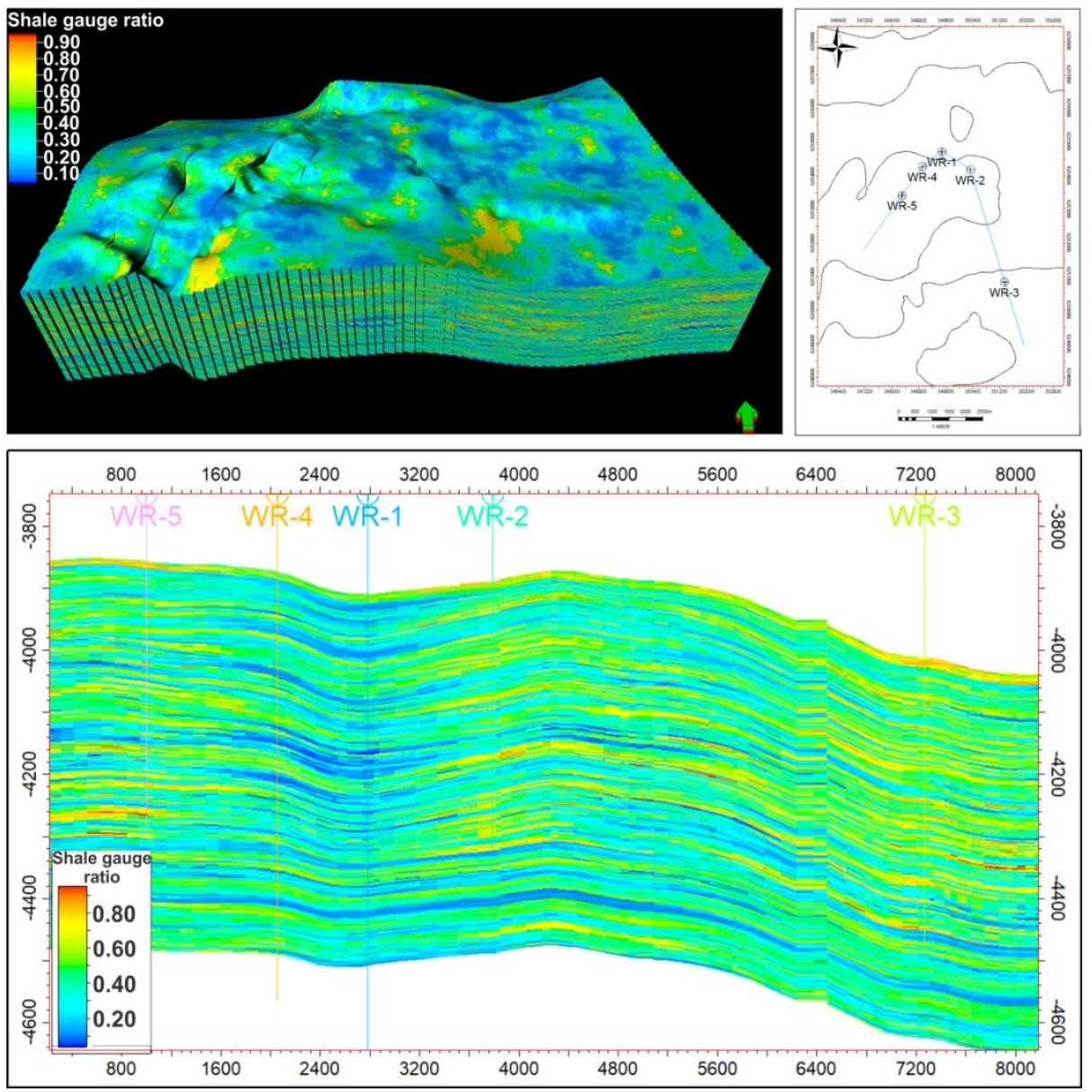

682 Fig. 24: Spatial model of sandstones and its cross section showing the distribution of shale in 683 the studied field. 


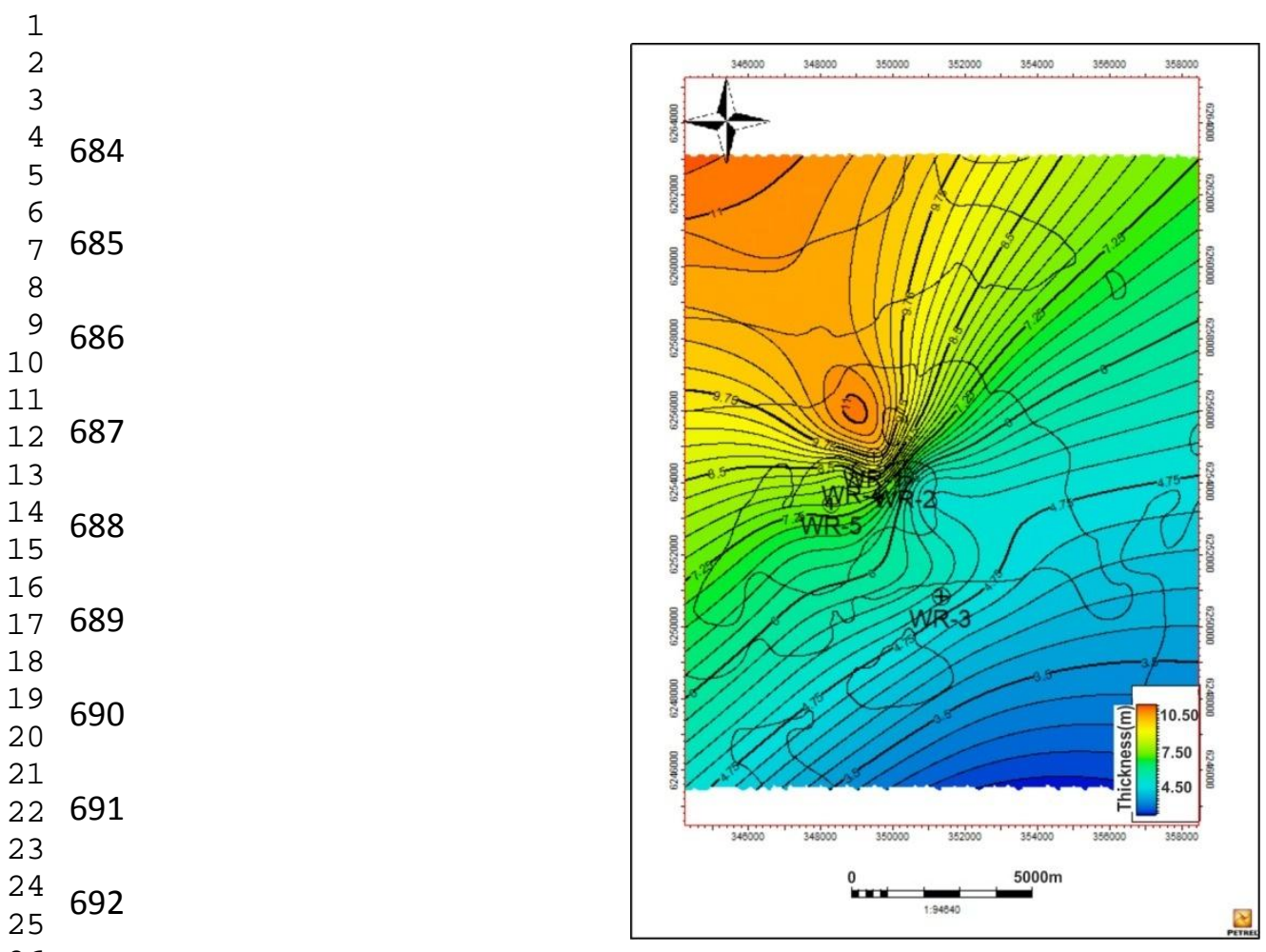

Fig. 25: Thickness map of sand in the Whicher Range Field.
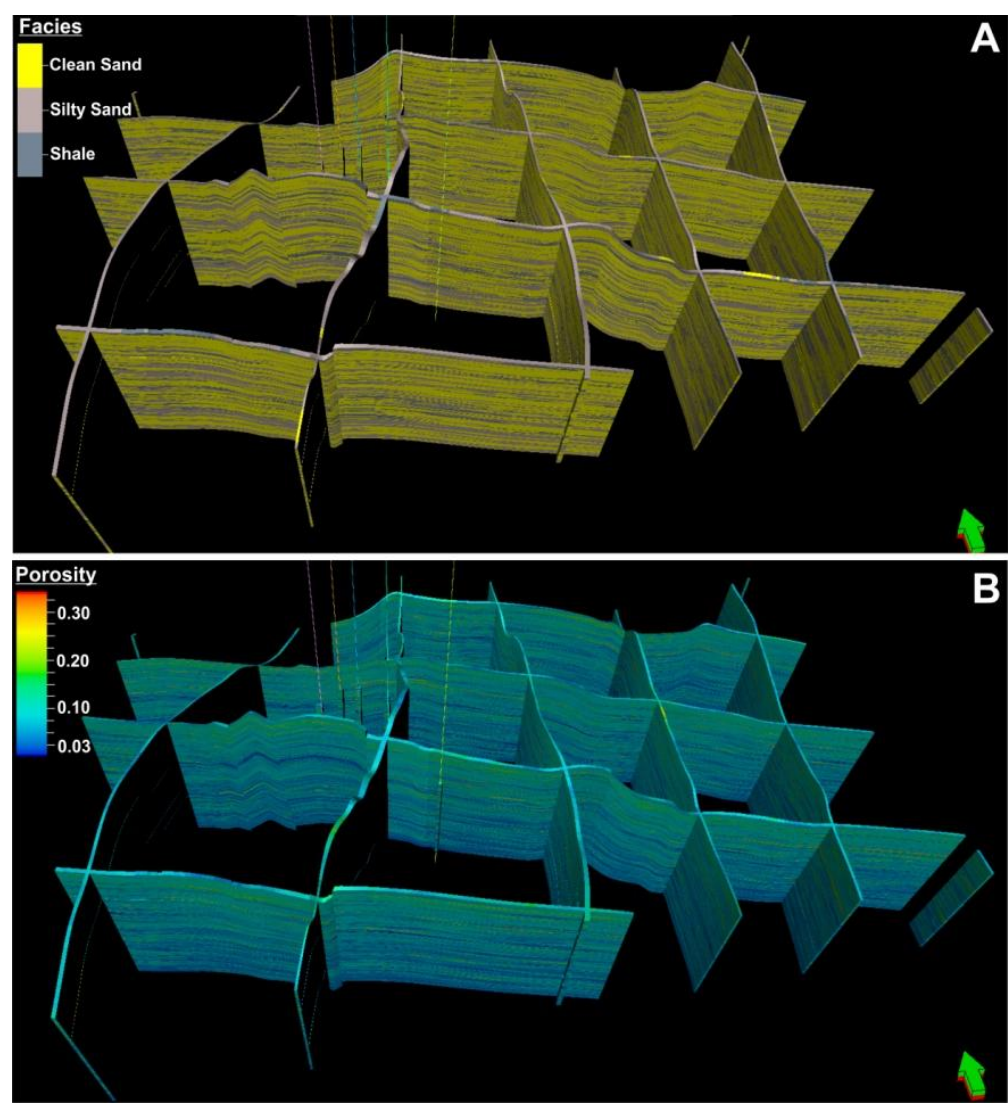


\section{Conclusion}

Tight sandstone facies of the late Permian Willespie Formation ofthe Whicher Range field show some degrees of heterogeneity and complexity in pore system properties and reservoir characteristics related to sedimentary texture and diagenetic features. These facies wihich have been deposited in a meandering river system can be categorized in five facies associations (FA1 to FA5) related to the channel, crevasse splay, levee, floodplain and paludal/lacustrine deposits. Based on core poroperm data analysis, medium to coarse grained facies of fluvial channel and crevesse spalygenerally show higher reservoir quality than fine grained and silty-shaly facies of flood plain and lacustrine subenvironments. In addition, diagenetic processes including compaction, cementation (authigenic clays, calcite and siliceous) and dissolution have severely modified pore system propeties of reservoir sandstones, although their effects, depending on primary depositional texture and mineralogical composition of reservoir facies, is different. Characterization of these sandstones in terms of three-dimensional facies and porosity modeling demonstrates different scales of heterogeneity within the reservoir interval of the field. In a large (field) scale, depositional environment of the reservoir facies has the main control on the distribution of reservoir zones in the field. As, most porous zones are coincident with coarse and high energy sandstone facies of fluvial channels that have been distributed as an individual or a set of stacked channels at the upper part of the formation.In contrast, diagenesis, in smaller (pore) scale, by modification of primary depositional texture, composition and pore system properties of the reservoir facies has imported its effect on internal reservoir heterogeneity. Unraveling the reservoir heterogeneity, derived from this study, demonstrates that the vertical and lateral variability in reservoir properties follows distinctive trends within the reservoir interval and can be considered in development and production strategies of the field such as horizontal drilling in upper parts of the formation.

\section{Acknowledgements}

The authors would like to appreciate the Curtin University of Technology, Department of Petroleum Engineering, Whicher Range Energy, and Department of Mines and Petroleum (WAPIMS) for providing necessary data to perform this study and to permit us to publish this paper. 


\section{References}

Albertão, G.A., Bampi, D., Schwedersky, G., 2001. Reservoir quality modeling and streamline simulation: An application in Campos Basin, Brazil. SPE 71353.

Caers, J., 2000. Adding local accuracy to direct sequential simulation. Math. Geol. 32 (7), 815850.

Ciftci, B., 2012. First order reservoir modeling of the Whicher Range Field tight gas sands. Whicher Range tight gas sands study, Western Australian Energy Research Alliance, Report 112, 288-307.

Crostella, A., Backhouse, J., 2000. Geology and petroleum exploration in the central and southern Perth Basin: Western Australia Geological Survey, Report 57, 85 pp.

Deutsch, C.V., 2002. Geostatistical Reservoir Modeling. Oxford University Press Inc., Oxford, UK, p. 385.

Deutsch, C.V., Journel, A., 1998. GSLIB: Geostatistical Software Library and User's Guide, second ed. Oxford University Press, New York, p. 369.

Dou, W., Liu, L., Wu, K., Xu, Z., Liu, X.,Feng, X., 2018. Diagenetic heterogeneity, pore throats characteristic and their effects on reservoir quality of the Upper Triassic tight sandstones of Yanchang Formation in Ordos Basin, China. Marine and Petroleum Geology, Volume 98, 243-257.

Du, S., Pang, S., Shi, Y., 2018. Quantitative characterization on the microscopic pore heterogeneity of tight oil sandstone reservoir by considering both the resolution and representativeness. Journal of Petroleum Science and Engineering 169, 388-392.

Dubrule, O., 2003. Geostatistic for Seismic Data Integration in Earth Models. SEG, EAGE, Tulsa, USA, p. 273.

Folk, R.L., Andrews, P.B., Lewis, D.W., 1970. Detrital sedimentary rock classification and nomenclature for use in New Zealand. New Zealand Journal of Geology and Geophysics 13, 937-968.

Hall, P. B., Kneale, R. L., 1992. Perth Basin rejuvenated. Australian Petroleum Exploration Association Journal 32 (1), 33-43.

Hsieh, A.I., Allen, D.M., MacEachern, J.A., 2017. Upscaling permeability for reservoir-scale modeling in bioturbated, heterogeneous tight siliciclastic reservoirs: Lower Cretaceous Viking 
Huang, W., Lu, S.,Hersi, O.S., Wang, M., Deng, S., Lu, R., 2017. Reservoir spaces in tight sandstones: Classification, fractal characters, and heterogeneity. Journal of Natural Gas Science and Engineering 46, 80-92.

Iasky, R.P., Young, R. A., Middleton M.F., 1991. Structural Study of the Southern Perth Basin by Geophysical Methods, exploration Geophysics, V 22, p 199-206.

Journel, A.G., Alabert, F.G., 1988. Focusing on spatial connectivity of extreme-valued attributes: Stochastic Indicator Models of Reservoir Heterogeneities. SPE Paper 18234.

Kadkhodaie-Ilkhchi, R., Rezaee R., Moussavi-Harami R., Nabi-Bidhendi, M., KadkhodaieIlkhchi, A., 2014. Seismic inversion and attributes analysis for porosity evaluation of the tight gas sandstones of the Whicher Range field in the Perth Basin, Western Australia. Journal of Natural Gas Science and Engineering 21, 1073-1083.

Kadkhodaie-Ilkhchi, R., Moussavi-Harami R., Rezaee R., Kadkhodaie-Ilkhchi, A., 2014. Analysis of the reservoir electrofacies in the framework of hydraulic flow units in the Whicher Range Field, Perth Basin, Western Australia. Journal of Petroleum Science and Engineering 111, 106-120.

Kiaei, H., Sharghi, Y., Kadkhodaiellkhchi, A., Naderi, M., 2015. 3D modeling of reservoir electrofacies using integration clustering and geostatistic method in central field of Persian Gulf. Journal of Petroleum Science and Engineering 135, 152-160.

Kulga, B., Artun, E., Ertekin, T., 2018. Characterization of tight-gas sand reservoirs from horizontal-well performance data using an inverse neural network. Journal of Natural Gas Science and Engineering 59, 35-46. doi:10.1016/j.jngse.2018.08.017.

Lai, J., Wang, G., Wang, S., Cao, J., Li, M., Pang, X., Zhou, Z., Fan, X., Dai, Q., Yang, L., He, Z., Qin, Z., 2018. Review of diagenetic facies in tight sandstones: Diagenesis, diagenetic minerals, and prediction via well logs. Earth-Science Reviews 185, 234-258. doi:10.1016/j.earscirev.2018.06.009.

Lai, J., Wang, G., Wang, Z., Chen, J., Pang, X., Wang, S., Zhou, Z., He, Z., Qin, Z., Fan, X., 2017. A review on pore structure characterization in tight sandstones. Earth-Science Reviews 177, 436-457. doi:10.1016/j.earscirev.2017.12.003. 
Li, Z., Wu, S., Xia, D., Zhang, X., Huang, M., Diagenetic alterations and reservoir heterogeneity within the deposition al facies: A case study from distributary-channel belt sandstone of Upper Triassic Yanchang Formation reservoirs (Ordos Basin, China). Marine and Petroleum Geology 86, 950-971.

Mahgoub, M.I., Padmanabhan, E., Abdullatif, O.M., 2018. Facies and porosity 3D models constrained by stochastic seismic inversion to delineate Paleocene fluvial/lacustrine reservoirs in Melut Rift Basin, Sudan. Marine and Petroleum Geology 98, 79-96.

Marshall, J.F., Lee, C.S., Ramsay, D.C., Moore, A.M.G., 1989. Tectonic controls on sedimentation and maturation in the offshore north Perth Basin. Australian Society of Exploration Geophysicists Journal 29, 450-465.

Martinius, A.W., Fustic, M., Garner, D.L., Jablonski, B.V.J., Strobl, R.S., MacEachern, J.A., Dashtgard, S.E., 2017. Reservoir characterization and multiscale heterogeneity mode ling of inclined heterolithic strata for bitumen-production forecasting, McMurray Formation, Corner, Alberta, Canada. Marine and Petroleum Geology 82, 336-361.

Miall, A.D., 2006. The Geology of Filuvial Deposits: Sedimentary Facies, Basin Analysis, and Petroleum Geology, Springer-Verlag, ${ }^{4}$ th printing, New York,582 pp.

Mory, A. J., Iasky, R. P., 1996. Stratigraphy and structure of the onshore northern Perth basin, Western Australia: Western Australia Geological Survey, Report No. 46, 101 pp.

Oluwadebi, A.G., Taylor, K.G., Patrick J. Dowey, P.J., 2018. Diagenetic controls on the reservoir quality of the tight gas Collyhurst sandstone formation, lower Permian, east Irish Sea basin, United Kingdom. Sedimentary Geology 371, 55-74. doi:10.1016/j.sedgeo.2018.04.006.

Orsini, C., Rezaee, R., 2012. Depositional Systems Sequence Stratigraphy Frameworks \& Geological Modelling of Fluvial Bodies. Geological Survey of Western Australia, Report 112, $405 \mathrm{p}$.

Owad-Jones, D., Ellis, G., 2000. Atlas of petroleum fields, onshore Perth Basin, Petroleum Division, DMEWA1, 122.

Pennezoil Far East Company, 1998. A review of the reservoir properties of the Sue Coal Measures in the Whicher Range Field area, South Perth Basin, Western Australia. 81 pp.

Pennezoil Far East Company, 1998. A review of the reservoir properties of the Sue Coal Measures in the Whicher Range Field area, South Perth Basin, Western Australia. 81 pp. 
Playford, P.E., Cockbain, A.E., Low, G.H., 1976. Geology of the Perth Basin, Western Australia. Geological Survey of Western Australia Bulletin 124, 311 pp.

Quaife, P., Rosser, J., Pagnozzi, S., 1994. The structural architecture and stratigraphy of the offshore northern Perth Basin, Western Australia. In: Purcell, P.G, Purcell, R.R. (Eds.), The Sedimentary Basins of Western Australia. Proceedings of Petroleum Exploration Society of Australia Symposium. Petroleum Exploration Society of Australia, 811-822.

Rezaee, R., Saeedi, A., Clennell, B., 2012. Tight gas sands permeability estimation from mercury injection capillary pressure and nuclear magnetic resonance data. Journal of Petroleum Science and Engineering 88-89, 92-99.

Sharifzadeh, A., 2008. Tight-Gas Resources in the Northern Perth Basin, Petroleum W.A. Magazine, 41-44.

Tobin, R.C., Mcclain, T., Lieber, R.B., Ozkan, A., Banfield, L.A., Marchand, A. M. E., McRae, L.E., 2010. Reservoir quality modeling of tight-gas sands in Wamsutter filed: Integration of diagenesis, petroleum systems, and production data. American Association of Petroleum Geologists Bulletin 94(8), 1229-1266.

Stroker, T.M., Harris, N. B., Elliott, W.C., Wampler, J.M., 2013. Diagenesis of a tight gas sand reservoir: Upper Cretaceous Mesaverde Group, Piceance Basin, Colorado. Marine and Petroleum Geology 40, 48-68.

Weber, K.J., 1980. Influence in fluid flow of common sedimentary structures in sand bodies. SPE Annual Technical Conference and Exhibition, Texas, USA, 21-24 September, SPE 9247.

Wei, W., Zhu, X., Meng, Y., Xiao, L., Xue, M., Wang, J., 2016. Porosity model and its application in tight gas sandstone reservoir in the southern part of West Depression, Liaohe Basin, China. Journal of Petroleum Science and Engineering 141, 24-37.

Xiao, D., Jiang, S., Thul, D., Lu, S., Zhang, L., Li, B., 2018. Impacts of clay on pore structure, storage and percolation of tight sandstones from the Songliao Basin, China: Implications for genetic classification of tight sandstone reservoirs. Fuel 211, 390-404.

Yang, H., Fu, J., Wei, X., Liu, X., 2008. Sulige field in the Ordos Basin: Geological setting, field discovery and tight gas reservoirs. Marine and Petroleum Geology 25, 387-400. 
Yao, T., Anil Chopra, A., 2000. Integration of seismic attribute map into 3D facies modeling.Journal of Petroleum Science and Engineering 27, 69-84.

Zhang, Li., Bai, G., Luo, X., Ma, X., Chen, M., Wu, M., Yang, W., 2009. Diagenetic history of tight sandstones and gas entrapment in the Yulin Gas Field in the central area of the Ordos Basin, China. Marine and Petroleum Geology 26, 974-989.

Zhi, G., Longde, S., Ailin, J.,Tao, L., 3-D geological modeling for tight sand gas reservoir of braided river facies. Petroleum Exploration and Development, 42(1), 83-91.

Zou, C., Zhu, R., Liu, K., Su, L., Bai, B., Zhang, X., Yuan, X., Wang, J., 2012. Tight gas sandstone reservoirs in China: characteristics and recognition criteria. Journal of Petroleum Science and Engineering 88-89, 82-91. 


\section{Unraveling the reservoir heterogeneity of the tight gas sandstones using the} porosity conditioned facies modeling in the Whicher Range field, Perth Basin, Western Australia

Rahim Kadkhodaie-Ilkhchi $^{1 *}$, Ali Kadkhodaie ${ }^{1}$, Reza Rezaee ${ }^{2}$, Vali Mehdipour ${ }^{3}$

1. Earth Science Department, Faculty of Natural Science, Tabriz, Iran

2. Department of Petroleum Engineering, Curtin University, Perth, Australia

3. DanaEnergy Company, Tehran, Iran

*Corresponding author: Tel./fax: +98 9128457310

E-mail: rahimkadkhodaee2005@gmail.com, rahimkadkhodaee2005@yahoo.com (R. KadkhodaieIlkhchi); kadkhodaie_ali@tabrizu.ac.ir (A. Kadkhodaie -Ilkhchi); r.rezaee@curtin.edu.au (R. Rezaee); mehdipour.vali@gmail.com (V. Mehdipour)

\section{Abstract}

Tight sandstones of the late Permian Willespie Formation constitute an important reservoir rock in the Whicher Range gas field of the Perth Basin. The sandstones under the effect of sedimentary conditions and diagenesis show some degree of heterogeneity reflecting in reservoir properties and production history. The Willespie Formation consists of fine to coarse-grained and gravelly feldspathic sandstones intercalated with shale, siltstone and coal, deposited in a meandering river system. Different diagenetic processes including compaction, cementation (authigenic clays, calcite and siliceous) and dissolution have severely affected the pore system properties of the reservoir sandstones, as they are considered as tight sandstones. In this study, three-dimensional modeling of reservoir sandstones has been performed using stochastic modeling algorithms for facies and porosity properties. A preliminary facies analysis of the main reservoir rocks based on core and well logs data provided the basis for reservoir zonation and modeling. Regarding the close relationship between acoustic impedance with depositional/diagenetic characteristics of reservoir facies and their porosity, this seismic attribute was used as a secondary parameter in porosity modeling. The results indicate a close relationship between sedimentary characteristics and reservoir properties. Based on the extracted models, most of the porous zones are related to the clean and coarse sandstones of the fluvial channels accumulating in the upper parts of the reservoir. In fact, initial sedimentary characteristics have the main impact on the distribution of reservoir zones, their thickness and continuity in the field and controlling large-scale reservoir heterogeneity which has been enhanced by the effect of diagenetic processes on the pore system properties and 
37 controlling the internal reservoir heterogeneity in next stages. Distinctive 38 variability in reservoir properties towards the upper reservoir units and also among 39 different wells can be considered for optimizing exploration and development 40 targets of the field.

41 Keywords: Tight sandstones, modeling, sedimentary characteristics, diagenesis, 42 reservoir heterogeneity

\section{$43 \quad$ 1. Introduction}

Tight gas sandstones are considered as a part of unconventional reservoirs in the world and especially in Australia. These reservoirs are mainly characterized by in situ permeability less than 0.1md (Rezaee et al., 2012; Zou et al., 2012). Challenges to reach the optimum production from these reservoirs indicate the complex nature of their pore system related to depositional and post-depositional controlling factors. Tight reservoir sandstones of the Whicher Range field in the Perth Basin of Western Australia, the target of this study, under the effect of primary sedimentary characteristics and diagenetic processes, show some complexities in pore system and reservoir properties affecting their production behavior in the field. The inherent reservoir heterogeneity and complexity observed in reservoir characteristics of tight gas systems means they should be treated with more caution for reservoir characterization targets, as these factors can lead to significant errors in estimation of reservoir properties, and finally misleading interpretations (Kulga et al., 2018). In recent years, many authors discussed the reservoir heterogeneity and pore system properties of tight sandstone reservoirs (e.g., Hsieh et al., 2017; Huang et al., 2017; Dou et al., 2017; Lai et al., 2017; Du et al., 2018). Some researchers have particularly highlighted the importance of diagenesis on reservoir properties of these reservoirs (e.g., Li et al., 2017; Lai et al., 2018; Oluwadebi et al., 2018; Xiao et al., 2018). Many works have been accomplished to reveal heterogeneity and reservoir characteristics of tight sandstone reservoirs through different modeling approaches (e.g., Zhi et al., 2015; Wei et al., 2016; Mahgoub et al., 2018). Investigation of tight sandstones of the Whicher Range field in the framework of a3D model of facies and petrophysical properties, accomplished in this study, can efficiently provide a comprehensive sense of the distribution of the reservoir zones in the field and identification the main factors controlling the reservoir quality. To meet these targets, a 
comprehensive investigation of depositional characteristics and diagenetic features of sandstone facies and their reservoir properties, through analysis of core and well logs data, was performed. Reservoir rock types were differentiated based on cluster analysis of well logs (especially GR), and were correlated between the wells. Three-dimensional geocellular models of facies and porosity properties based on stochastic algorithms were extracted. As a result, the extracted models were used to describe the reservoir heterogeneity of tight sandstones in both the large scale related to depositional characteristics, and the small scale related to the effect of diagenetic processes on pore system properties.

\section{Geology, tectonic setting and stratigraphy}

Perth Basin is considered as a rift basin with north-south trending which has been located on the western border of Western Australia and adjacent to Yilgarn Craton (Fig. 1A). Darling Fault in the eastern part of the basin has exerted significant control on its formation. The basin formation and evolution is related to two main tectonic phases with tensional system. The first phase which has been occurred in the late Permian is associated with the formation of a rifting basin. The second event which is correlated with the breakup and separation of Australia plate from India has occurred during the late Jurassic to early Cretaceous (Quaife et al. 1994; Marshall et al. 1989; Mory and Iasky, 1996).The basin contains mainly clastic rocks deposited in a developing rift system from Permian to recent (Owad-Jones and Ellis, 2000). Whicher Range field is located $200 \mathrm{~km}$ south of Perth and $22 \mathrm{~km}$ south of the city of Busselton in Western Australia. This field is a large faulted anticline with the northeast trend in the Bunbury Trough (Fig. 1B), formed as a result of intense strike-slip movements during continental breakup (Crostella and Backhouse, 2000; Owad-Jones and Ellis, 2000; Sharifzadeh, 2008).The Permian interval of Bunbury Trough includes the Sue Group that is subdivided into five formations including the Woodynook Sandstone, Rosabrook Coal Measures, Ashbrook Sandstone, Redgate Coal Measures, and Willespie Formation, in ascending order. These formations consist predominantly of poorly-sorted feldspathic sandstone deposited in clastic system. The Sandstone beds of the Willespie Formation with the late Permian in age constitute the reservoir zone of the field (Fig. 2A).This Formation lies conformably above the Redgate Coal Measures Formation, and the upper boundary with the Triassic Sabina Sandstone is apparently conformable (Crostella and Backhouse, 2000). Coal and carbonaceous 
104 shales within the interval are considered as hydrocarbon sources, as it said the 6105 reservoir sandstones have a self-sourcing rock (Tobin et al., 2010). Shales,
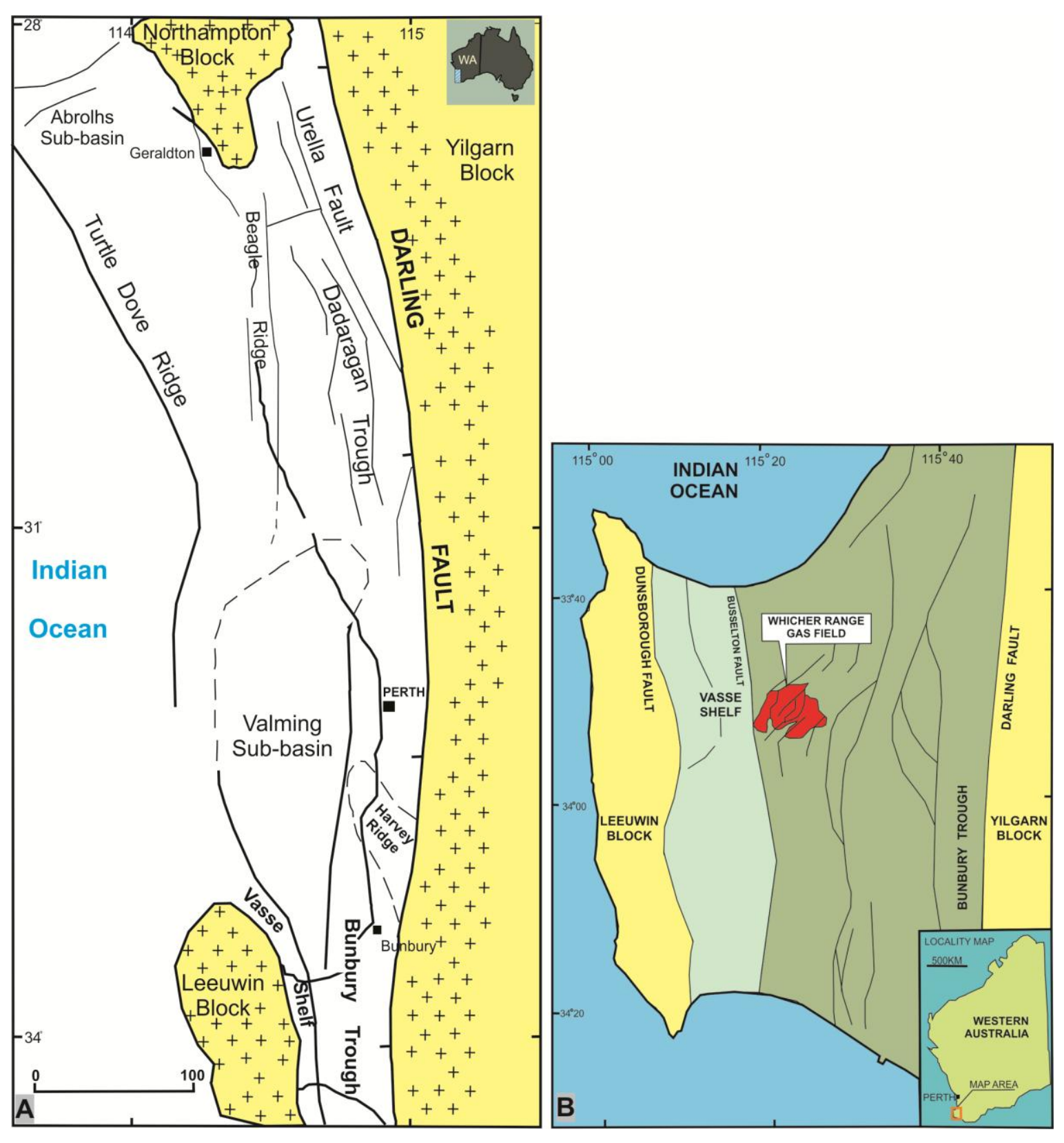
carbonaceous siltstones and coals have acted as intraformational cap rocks and permeability barriers for the reservoir sandstones of the field.

Fig. 1: A) General map of the Perth Basin in Western Australia (modified after Hall and Kneale, 1992). B) Location of the Whicher Range gas field in the Perth Basin (modified after 111 Sharifzadeh, 2008). 

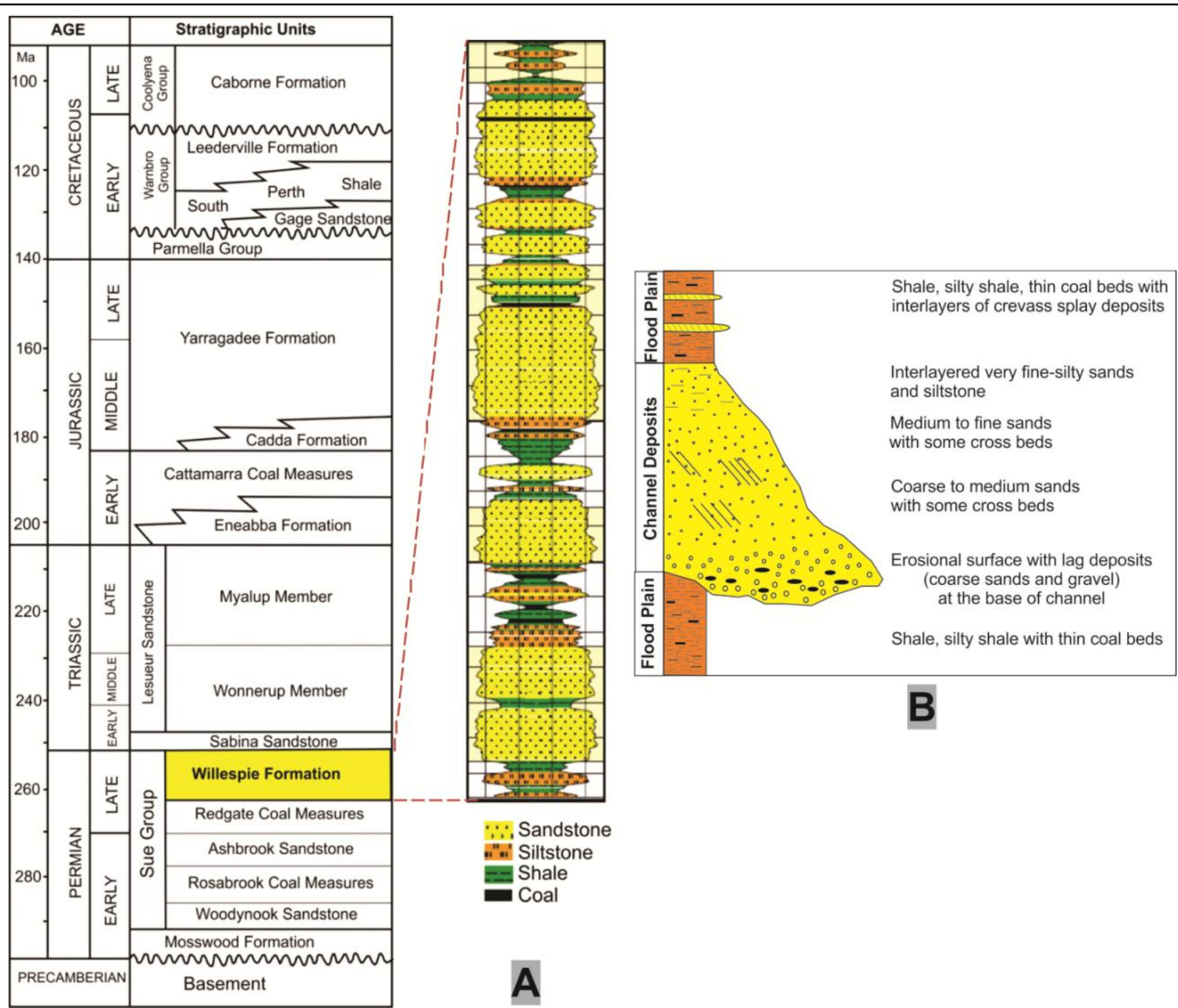

Fig.2: A) Stratigraphy succession of the southern Perth Basin (Playford et al., 1976). The late Permian Willespie Formation, as reservoir rock of the Whicher Range field, with lithology composed of sandstone, siltstone, shaleand coal is highlighted in the stratigraphic column. B) A schematic picture showing fining upward interval of the Willespie sandstones within a meandering river system environment.

\section{Data and Methodology}

In this study, in order to model and investigate facies and reservoir characteristics of the Willespie Formation sandstones in the Whicher Range field, core/cutting 122 and well log data and information from five drilled wells (WR1, WR2, WR3, WR4 123 and WR5) in the field, provided by Curtin University of Technology, Department 
of Petroleum Engineering, with input from Department of Mines and Petroleum (WAPIMS) and Whicher Range Energy, were used. Available core data are from four wells (WR1 to WR4) in several intervals of the Willespie Formation.

At the first stage of this study, sedimentary characteristics of the reservoir rocks, based on the results from core and cutting description (lithofacies) associated with petrographic studies (petrofacies) in five wells were inspected. The main diagenetic processes including compaction, cementation and dissolution were described and interpreted based on the results from petrography and SEM analysis. Then,reservoir characteristics of sandstone facies through core poroperm data analysis were studied, and correlated with their compositional and textural characteristics, dominant diagenetic features and pore types by which the main factors controlling the reservoir quality and pore system properties of tight sandstones in the field were recognized. At the second stage, in order to reach a comprehensive understanding of the factors controlling the internal reservoir heterogeneity and analyze the distribution of reservoir zones in the field, facies and porosity attitudes of reservoir sandstones were investigated through geostatistical modeling. For facies modeling, Sequential Indicator Simulation (SIS), as proposed by many researchers (e.g., Journel and Alabert, 1988; Deutsch and Journel, 1998; Dubrule, 2003; Caers, 2000; Kiaei et al., 2015), and for porosity modeling, Sequential Gaussian Simulation (SGS) as a common stochastic method introduced in the literature (e.g., Albertão et al., 2001; Martinius et al., 2017) were used. Facies codes extracted from previous work (i.e., Kadkhodaie-Ilkhchi et al., 2013) through well logs (especially GR) clustering technique were utilized. This technique that analyzes a data set (well logs), classifies log data into subsets (clusters), in which each cluster shows specific attitudes of well logs responses. In this respect, the first step is to compute the distance between data objects (well log data) based on a distance function (e.g., Euclidean function). In the next step, linking between distance data is made using an appropriate linkage function (e.g., Ward function), which based on a hierarchical cluster tree or dendrogram is generated. Different clusters in the dendrogram are hierarchically linked together from small clusters with higher similarity degree to large clusters having lower similarity degree. In the final step, using a set of cutoff values, clusters are extracted from dendrogram. As a result, three main facies including clean sandstones $(\mathrm{GR}<80)$, silty sandstones $(80<\mathrm{GR}<130)$, and shale $(\mathrm{GR}>130)$ are 
identified. These facies also were correlated with the sedimentary characteristics derived from core studies. To start the reservoir modeling, one interpreted structure map from the top of the Willespie Formation and fault data in association with petrophysical logs (GR, DT, RHOB and NPHI) of five drilled wells were employed to build the framework of the model. Finally, the resultant facies and porosity models were extracted by geostatistical methods (i.e., stochastic algorithms such as SIS and SGS) which based on the variation and distribution of these characteristics in the field are discussed.

\section{Facies and sedimentary environment of reservoir sandstones}

The Willespie Formation has a sedimentary interval consisting of fine to coarsegrained and gravelly feldspathic sandstones intercalated with shale, siltstoneand coal. This interval, based on the results from core description (lithology and depositional features and structures), vertical sedimentary sequence and regional geology has been developed in a meandering river system with low to medium sinuosity. Reservoir sandstones in this system can be categorized in five facies associations (FA1 to FA5) related to the channel, crevasse splay, levee, floodplain and paludal/lacustrine deposits (Table 1). Sandstone facies within the channels show a fining upward sequence in which coarse and gravelly sandstones with an erosional surface have been deposited as bed load at the base of the channel and fine-grained facies with decreasing the energy started to deposit at top of the sequence (Figure 2B). Low energy silty and shaly facies in association with coal constitute the floodplain and paludal deposits. Petrographic evidences demonstrate that quartz (mostly monocrystalline and minor polycrystalline), potassium feldspar and plagioclase are the main constituents of the sandstones, and rock fragments, micas (biotite and muscovite) and heavy minerals (garnet, zircon, tourmaline, epidote, magnetiteand goethite) have low frequency. Rock fragments are volcanic, metamorphic with afew chert and sedimentary types. Sandstones are clay-rich with weak sorting and subangular to subrounded grains. The sandstones are texturally and mineralogically immature to submature, and according to Folk et al (1970), they are classified as feldspathic to subfeldspathic arenite (Fig. 3). Textural and diagenetic characteristics as well as average poroperm values of the Willespie sandstones have been given in Table2. 
Table 1: Sedimentary characteristics of sandstones facies of the Willespie Formation derived

\begin{tabular}{|c|c|c|c|c|}
\hline $\begin{array}{c}\text { Facies } \\
\text { Association }\end{array}$ & Facies & $\begin{array}{c}\text { Sedimentary } \\
\text { feature/Structure }\end{array}$ & $\begin{array}{l}\text { Sedimentary } \\
\text { Environment }\end{array}$ & $\begin{array}{c}\text { Core Photograph } \\
\qquad 10 \mathrm{~cm} \\
\end{array}$ \\
\hline FA-1 & $\begin{array}{l}\text { Gravely and coarse } \\
\text { grained sandstone } \\
(\mathrm{Gmm}) \text {, massive to } \\
\text { cross-bedded medium } \\
\text { to fine -grained } \\
\text { sandstone (Sp, Sm) }\end{array}$ & $\begin{array}{l}\text { cross bedding, } \\
\text { fining -upward, } \\
\text { erosional surface }\end{array}$ & Channel fill & Gmm \\
\hline FA-2 & $\begin{array}{l}\text { Cross-laminated to } \\
\text { laminated medium to } \\
\text { fine-grained } \\
\text { sandstone (Sl, Sr), } \\
\text { siltstone }\end{array}$ & $\begin{array}{l}\text { Lamination, cross } \\
\text { lamination, } \\
\text { bioturbation }\end{array}$ & $\begin{array}{l}\text { Channel margin } \\
\text { (levees, bar } \\
\text { tops) }\end{array}$ & $\overrightarrow{\mathrm{Sr}}$ \\
\hline FA-3 & $\begin{array}{l}\text { Heterolitic lithology: } \\
\text { Sharp-based, massive, } \\
\text { laminated to ripple } \\
\text { cross-laminated and } \\
\text { bioturbated fine } \\
\text { sandstone ( } \mathrm{Sm}, \mathrm{Sr} \text {, } \\
\mathrm{Sb} \text { ), locally with } \\
\text { cross-bedded (Sx) } \\
\text { overlain by very fine } \\
\text { sandstone-siltstone } \\
\text { and siltstone }(\mathrm{Ht}, \mathrm{Hb} \text {, } \\
\text { Ml) }\end{array}$ & $\begin{array}{l}\text { Lamination, cross } \\
\text { lamination, cross - } \\
\text { bedding, fining } \\
\text { upward }\end{array}$ & Crevasse splay & $\frac{\mathrm{D}}{\mathrm{Sb}}$ \\
\hline FA-4 & $\begin{array}{l}\text { Planar laminated to } \\
\text { carbonaceous } \\
\text { mudstone (Ml), minor } \\
\text { interbedded very fine } \\
\text { sandstone and } \\
\text { mudstone (Ht) }\end{array}$ & $\begin{array}{l}\text { coarsening up and } \\
\text { fining upwards } \\
\text { trends }\end{array}$ & $\begin{array}{l}\text { Flood plain and } \\
\text { distal crevasse } \\
\text { splay }\end{array}$ & MI \\
\hline FA-5 & $\begin{array}{l}\text { Coal seams and } \\
\text { lamination }(C)\end{array}$ & $\begin{array}{l}\text { interlamination of } \\
\text { mudstone and } \\
\text { siltstone with thin } \\
\text { coals }\end{array}$ & Paludal deposit & G \\
\hline
\end{tabular}



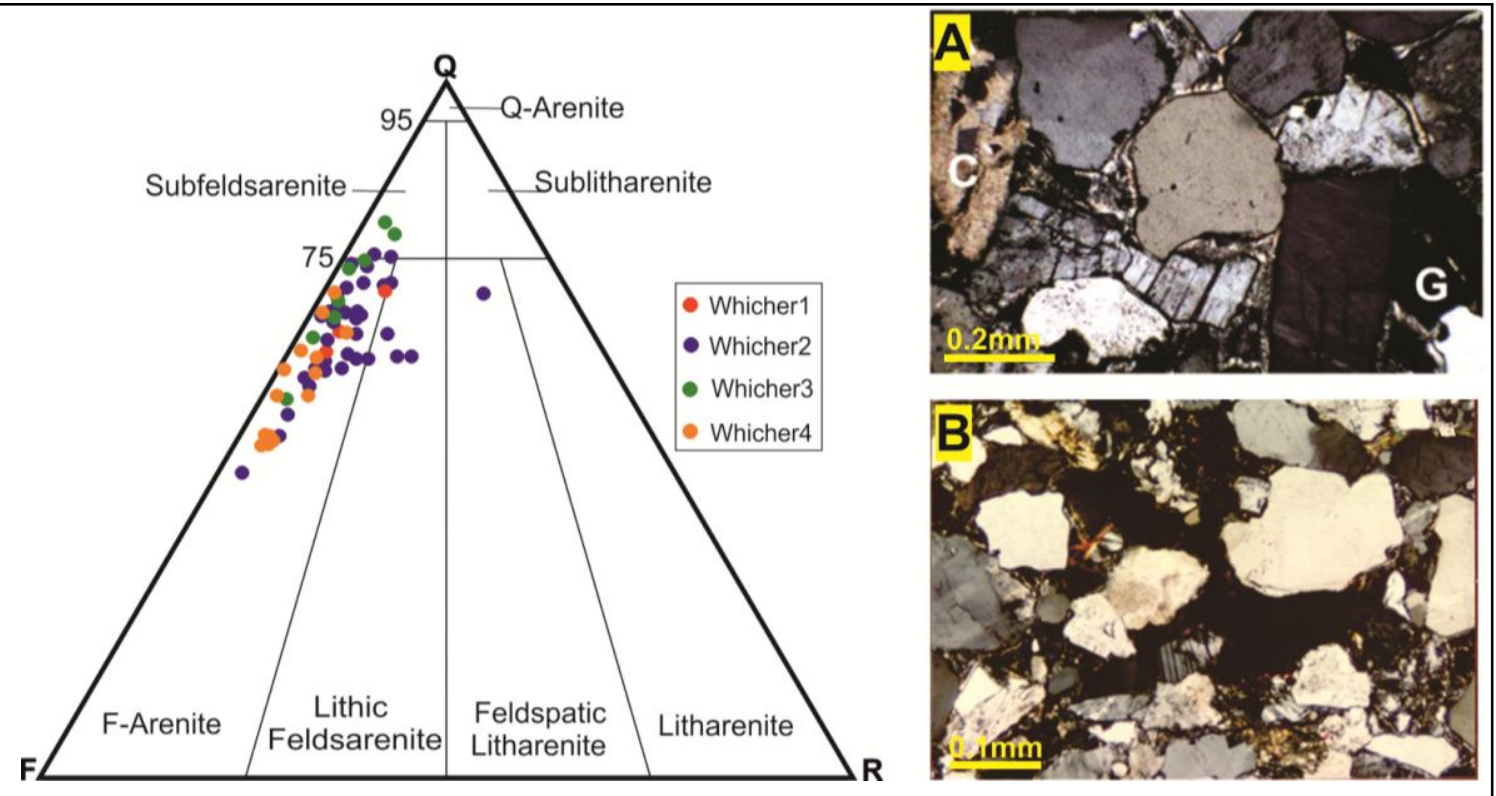

Fig.3: QFR plot of the Whicher Range sandstones showing the majority are feldspathic with some sub-feldspathic arenite. Q: monocrystalline and polycrystalline quartz; F: total feldspar; R: total lithic fragments (after Folk et al., 1970).Photomicrographs A and B show detrital composition of Whicher Range sandstones. A: Sandstone with subangular to subrounded quartz, feldspar (with cleavage and/or twinning) and minor grains such as garnet $(\mathrm{G})$ and replacement of a primary grain by calcite (c). B) Sandstone with quartz and feldspar grains and detrital biotite flakes (brown to dark).

Table 2: A summary of textural and sedimentary characteristics, diagenetic features and poroperm values of Willespie Formation in the Whicher Range field.

\begin{tabular}{|c|l|}
\hline $\begin{array}{c}\text { Sedimentary and } \\
\text { diagenetic features }\end{array}$ & \multicolumn{1}{c|}{ Description } \\
\hline Lithology & Feldspathic sandstone, siltstone, shale, coaly shale, coal \\
\hline Grain size & Fine to coarse-grained and in some cases gravelly sandstone \\
\hline Sorting & Weak to moderate (in fine-grained sandstones is well) \\
\hline Roundness & Mostly subrounded to subangular \\
\hline $\begin{array}{c}\text { Textural and } \\
\text { mineralogical maturity }\end{array}$ & Immature to submature \\
\hline Diagenetic features & Compaction (mostly physical), cementation, dissolution, replacement \\
\hline Cement type & Authigenic clays, calcite, silica \\
\hline Pore type & $\begin{array}{l}\text { Isolated dissolution pores, microporosity in clay minerals, minor } \\
\text { primary intergranular pores }\end{array}$ \\
\hline Porosity $(\%)$ & \multicolumn{2}{c}{$5-16 \%$} \\
\hline Permeability $(\mathbf{m D})$ & \multicolumn{2}{c}{$<0.1$ to $>1 \mathrm{mD}$} \\
\hline
\end{tabular}




\section{Reservoir properties}

Investigation of the Willespie Formation from reservoir quality point of view indicates that pore system properties of the reservoir sandstones show intimate relationship with their primary depositional characteristics, mineralogy and diagenesis. These parameters are described as follows.

\subsection{Depositional characteristics}

Changes in depositional environments have been proved to be a control in reservoir properties (Weber, 1980). In a comparison between the reservoir sandstone facies with their core porosity and permeability data, Orsini and Rezaee (2012) demonstrated that low reservoir quality is mostly related to floodplain (FP), crevasse splays (CS) and channel margins $(\mathrm{MCH})$ whereas better qualities are associated with channel $(\mathrm{CH})$ and crevasse channel facies ( $\mathrm{CSCH}$ ) (Fig. 4). Overall, intervals of lower reservoir quality seem to relate to the more argillaceous facies which is more likely to be controlled by the depositional environment. In addition, according to the core poroperm cross plot of reservoir sandstones, shown in Figure 5, there is generally a meaningful relationship between grain size and reservoir properties of the facies; the larger grain size, the reservoir quality is higher. This means initial depositional facies and texture play an important role on controlling the pore system properties of tight sandstones and reservoir heterogeneity in the field.

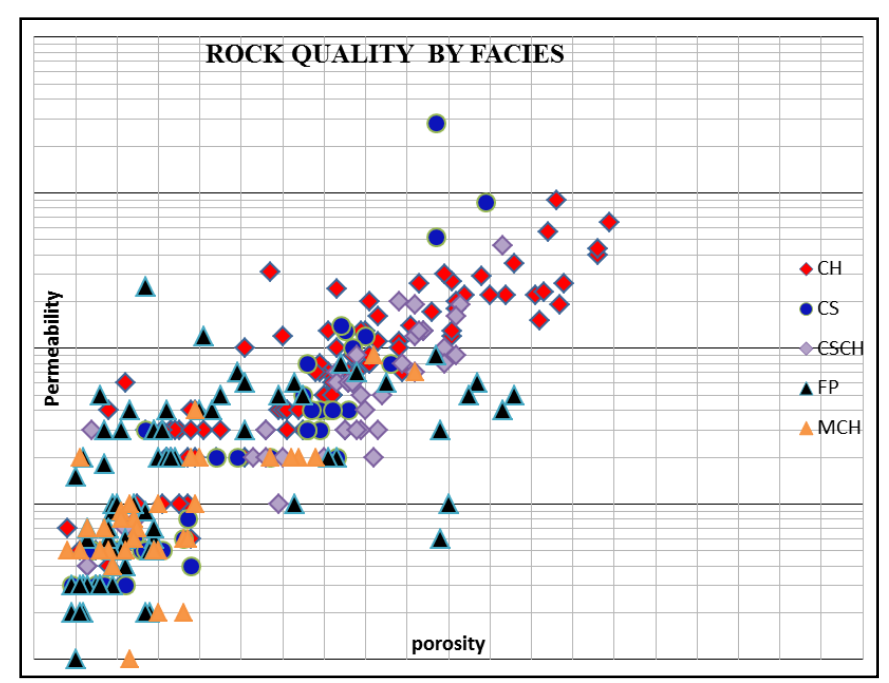

Fig. 4: Porosity and permeability plot for different facies in Whicher Range field (after Orsini and Rezaee, 2012). 


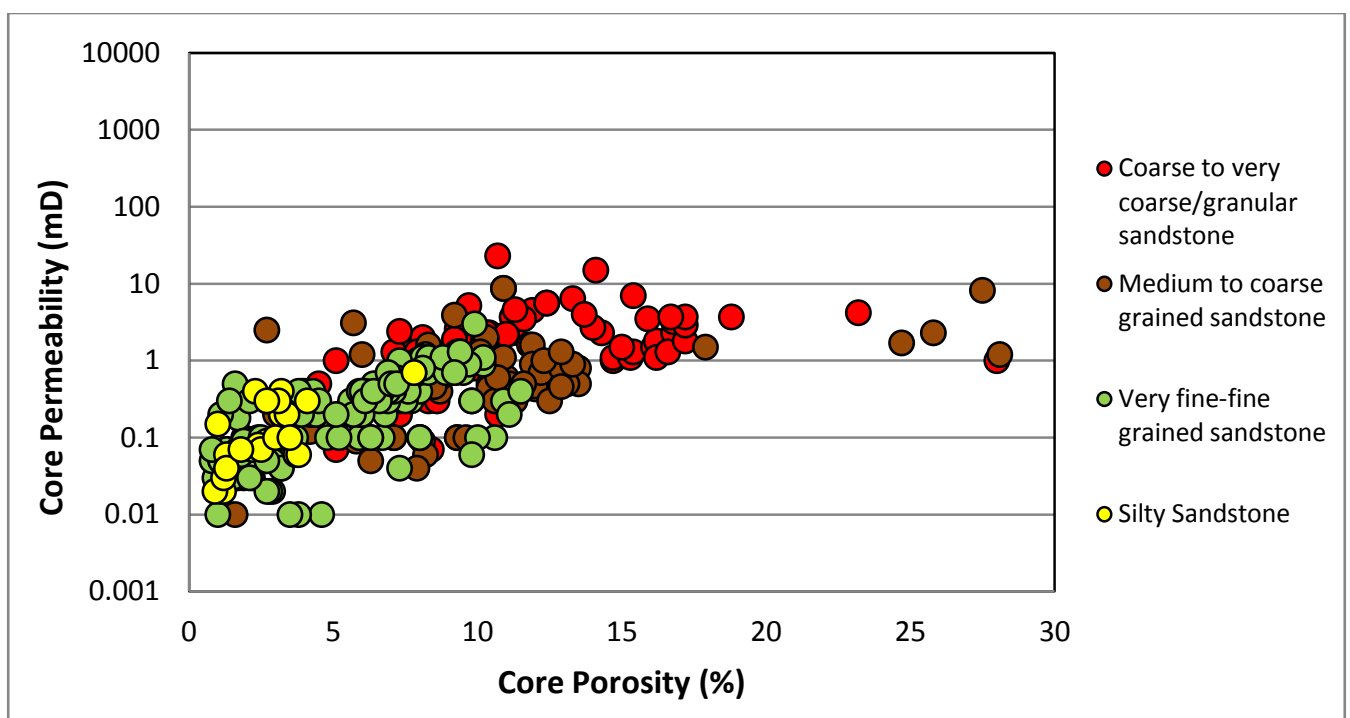

Fig. 5: Core poroperm cross plot for reservoir sandstones of the field based on their grain size.

\subsection{Diagenesis and mineralogy}

Diagenesis has the main control on pore system properties of reservoir sandstones in the field. In fact, sandstone facies of the Whicher Range field under the effect of diagenetic processes are characterized by a compacted and cemented fabric with low to high porosity and especially low permeability, as they are considered tight. Compaction mainly as mechanical at the first stages of diagenesis, and cementation by quartz, calcite and clay minerals at the next stages are the main diagenetic overprints affecting the pore system properties of the sandstones. In comparison, dissolution as an improving diagenetic agent of reservoir quality, is not widespread and the dissolution vugs are mostly isolated and non-effective. Figure 6, schematically shows the integrated effect of different diagenetic processes and their impact on tightness nature of the reservoir sandstones.

SEM photomicrographs of diagenetic features within the reservoir are shown in Figure 7.These facies show some similarity in diagenetic features (e.g., cementation by silica and clay minerals) with tight reservoir sandstones in other basins such as Ordos Basin of China (Yang et al., 2008; Zhang et al., 2009), Piceance Basin of Colorado (Stroker et al., 2013) and the Greater Green River Basin of Wyoming (Tobin et al., 2010). In addition to initial sedimentary texture (grain size), one factor which also controls the effect of diagenesis within the 
reservoir is the mineralogical composition of sandstone facies that is attributed to

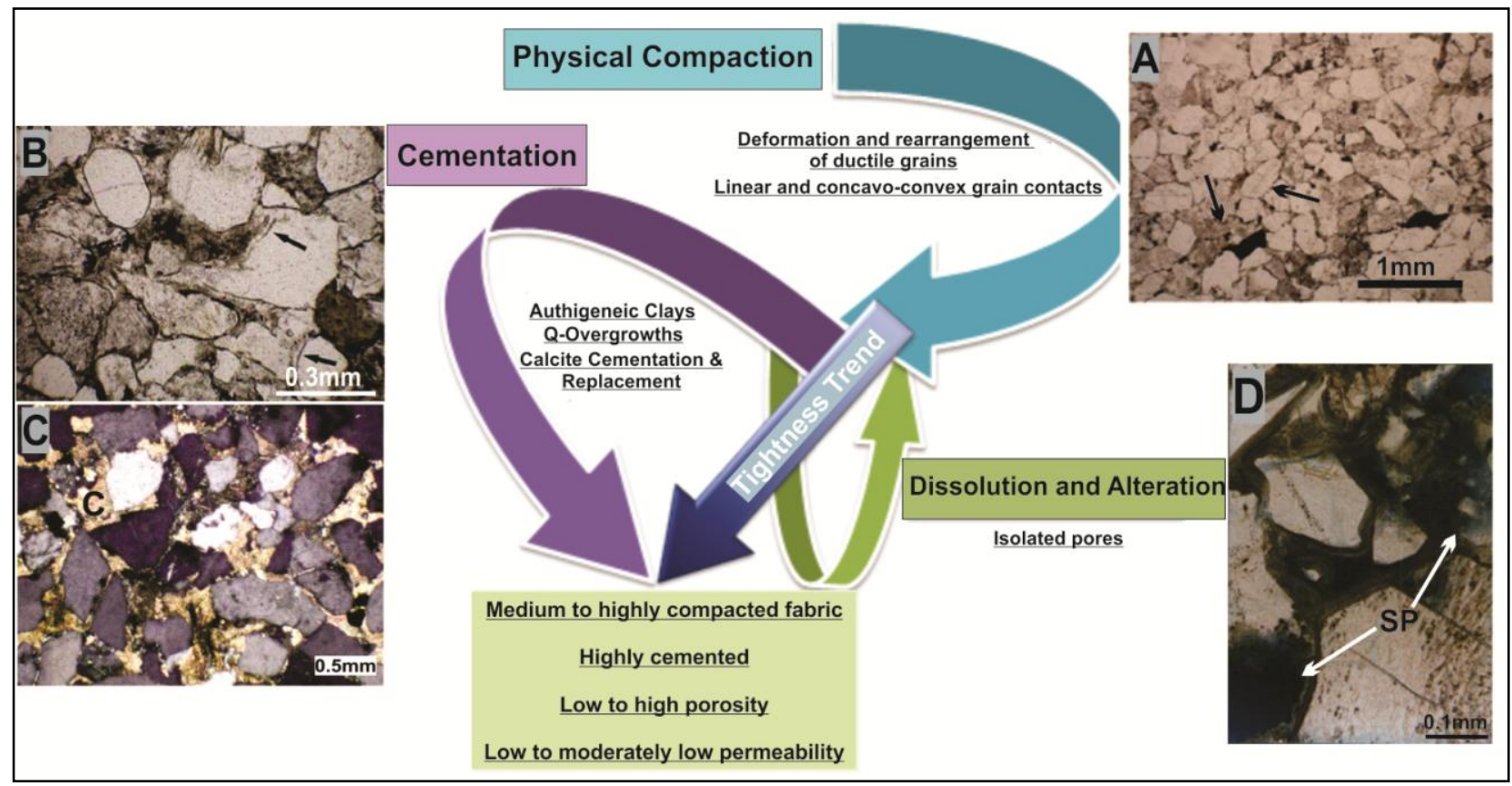
micas and rock fragments. These components, in fact, have provided and accelerated the condition for acting of compaction, alteration and dissolution within the reservoir that has been resulted in modification of pore system properties and increasing of internal reservoir heterogeneity. Figure 8 (A and B) shows how the compaction has differently acted on two sandstone facies of the reservoir. According to this figure, sandstone facies A due to the fine-grained texture and also the presence of ductile grains (mica) has been more compacted than medium to coarse-grained facies B.

Fig. 6: A schematic picture showing the integration effects of compaction, cementation and dissolution on tightness nature of reservoir sandstones in the Whicher Range field. Cementation by clay minerals, silica (B) and calcite (C) in association with physical compaction (A) has the main effect on decreasing the reservoir quality and creation a compacted and cemented fabric of reservoir sandstones. Arrows in photomicrograph A show the effect of physical compaction in grain contact boundaries, and in photomicrograph $\mathrm{B}$, overgrowth quartz cement, and in photomicrograph $\mathrm{D}$, they show secondary pores (SP) from dissolution. 

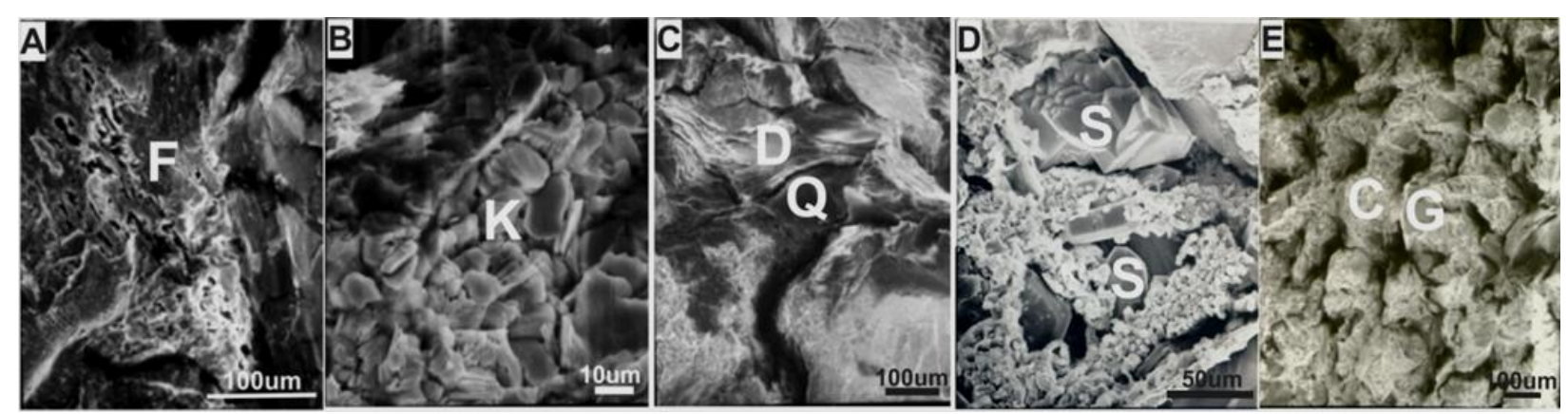

Fig. 7: SEM photomicrographs of diagenetic features within the reservoir sandstones. A) Partially dissolution of feldspar grain $(\mathrm{F})$ is associated with the formation of small secondary pores. B) Kaolinite booklets as pore-filling clay cement. C) A grain (D) which has been undergone ductile deformation between quartz grains (Q). D) Pores have been partially occluded by silica overgrowths (s) and by the growth of authigenic clays (kaolinite and smectite). E) Detrital grains $(G)$ have been surrounded by clay $(C)$.

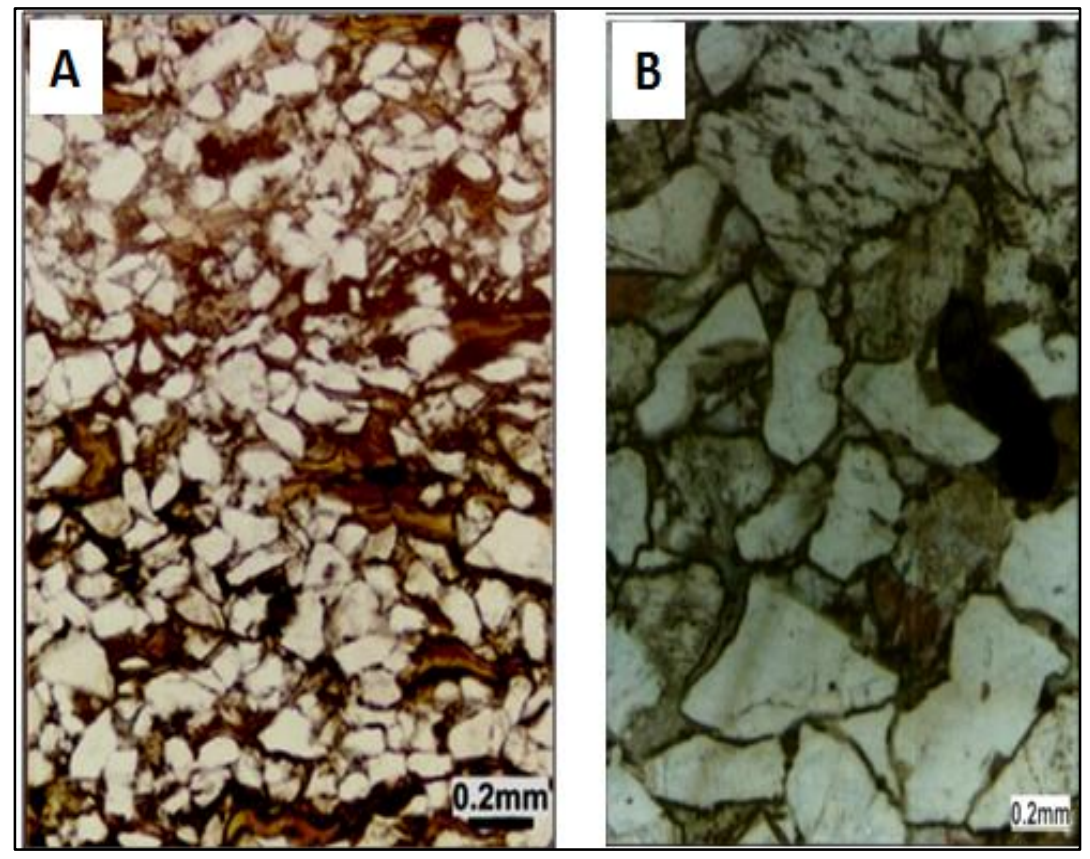

Fig. 8: Different effect of compaction on two sandstone facies of the Whicher Range field. A: fine-grained facies with ductile grains between quartz grains. B: medium to coarse-grained sandstone facies. 


\section{Geocellular modeling}

In this stage, after gaining an understanding of depositional facies and environments and diagenetic features of the reservoir sandstones, work for building a 3D model showing the distribution of facies and petrophysical characteristics in the field was started. Accordingly, all relevant data derived from wells including core, well log, wellhead, well top in association with structure map for the top of the formation and fault data were loaded into the geological model database. Afterwards, reservoir modeling, according to the workflow shown in Figure9, was accomplished. The stages are briefly described as follows.

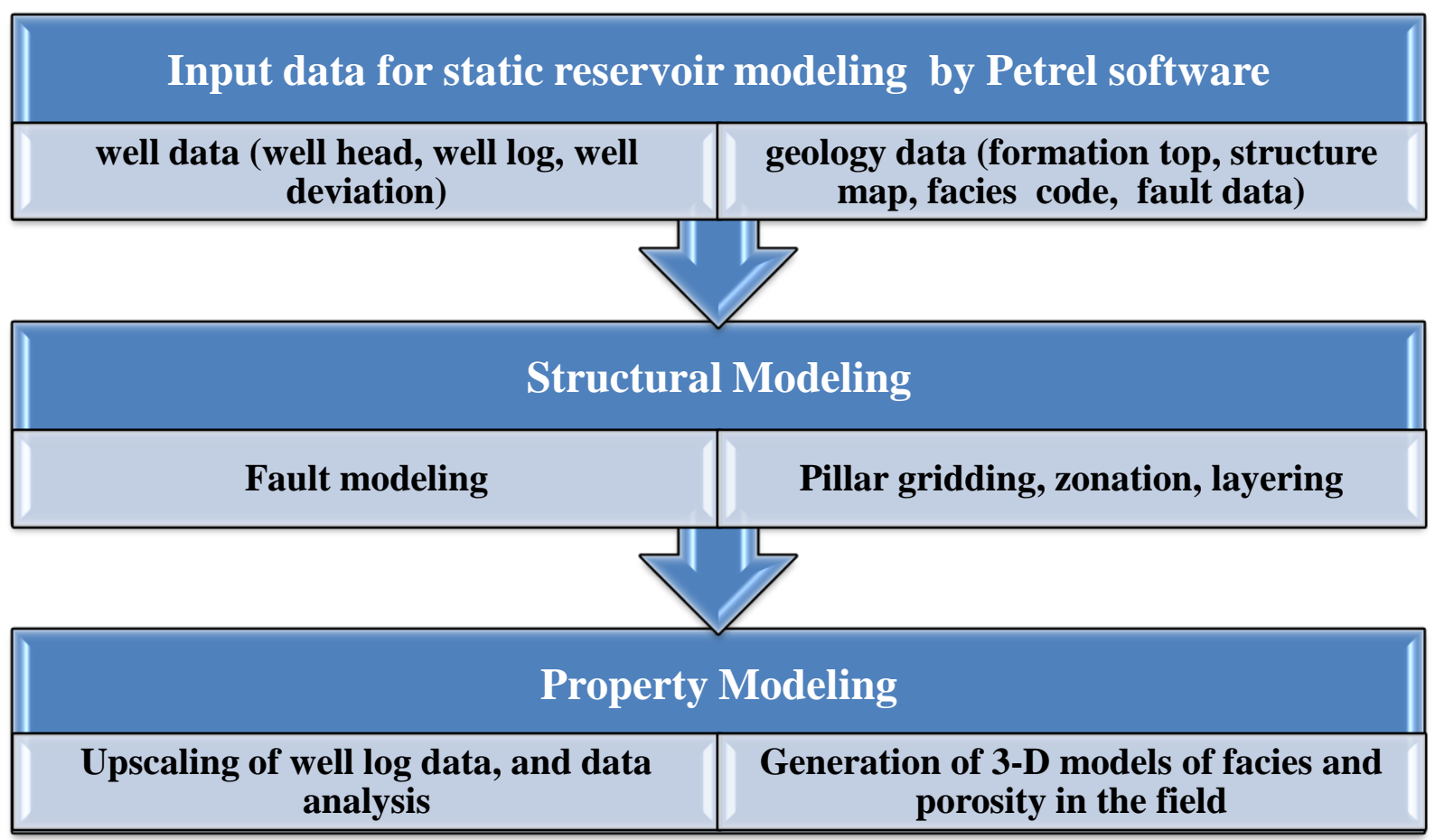

299 Fig.9: Workflow for geocellular modeling of the Willespie Formation in the Whicher Range 300 gasfield.

302 6.1. Structural Modeling

Anticline structure of the Whicher Range field, as mentioned above, has been affected by tectonic movements and the resultant faulting. Such faults have an important role on reservoir compartmentalization, and they are predominantly NNE-SSW oriented with an average trend of $010^{\circ} \mathrm{N}$. This trend aligns well with 
the structural trend of the Bunbury Through (Ciftci, 2012). Data for these faults were loaded into the geological model database to constitute the fault surfaces within the 3D model (Fig.10). Afterwards, the reservoir volume was gridded by cells with certain dimensions.

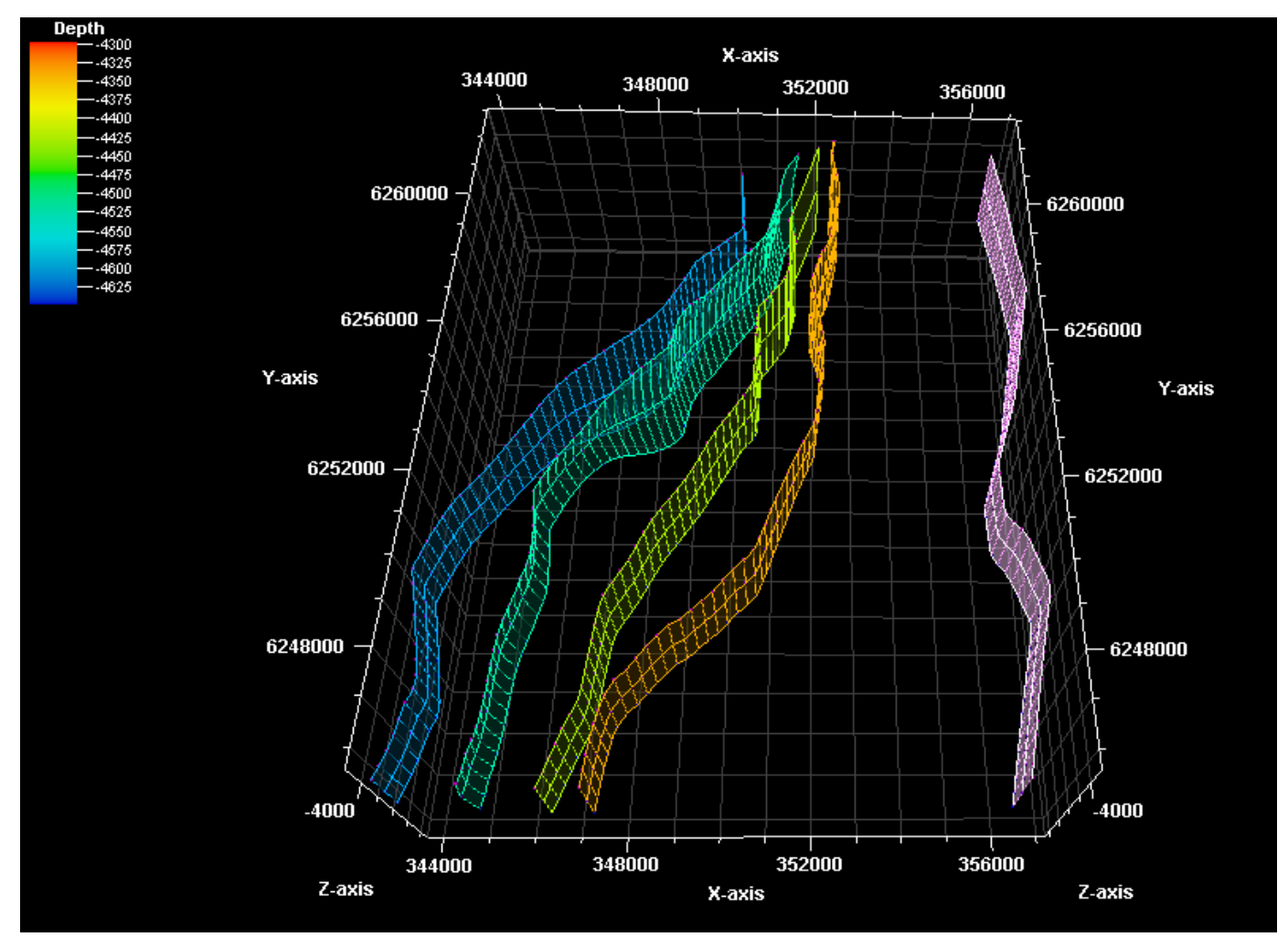

322 Fig.10: The position of faults with NNE-SSW trend used in reservoir modeling of the Whicher 323 Range field.

324 The Willespie Formation in the Whicher Range field due to the alternation and 325 overlapping of various units of sandstone, siltstone, shaleand coal shows a high 326 lateral and vertical heterogeneity in lithology. Therefore, the reservoir interval 327 based on the main sandstone packages is classified into numerous reservoir 328 intervals, named as Latin letters (A, B, C..., W), in a descending order. Sandy 329 packages which are correlatable between the wells, in fact, are identified based on 330 DST and production flow test information provided by Pennzoil Far East Company 331 (1998), and considered as reservoir units throughout the well interval. Also, non332 reservoir shaly and silty intervals between them were named as sub-letters (i.e., 333 A2, B2, C2 ...) in this study (Fig.11).In geocellular modeling of the Whicher 334 Range sandstones, the interpreted structure map for the top of the Willespie 
5335 Formation was used as a base surface (Fig. 12). Afterwards, based on such a map, 6336 the surfaces for the different zones within the reservoir were determined. Then,

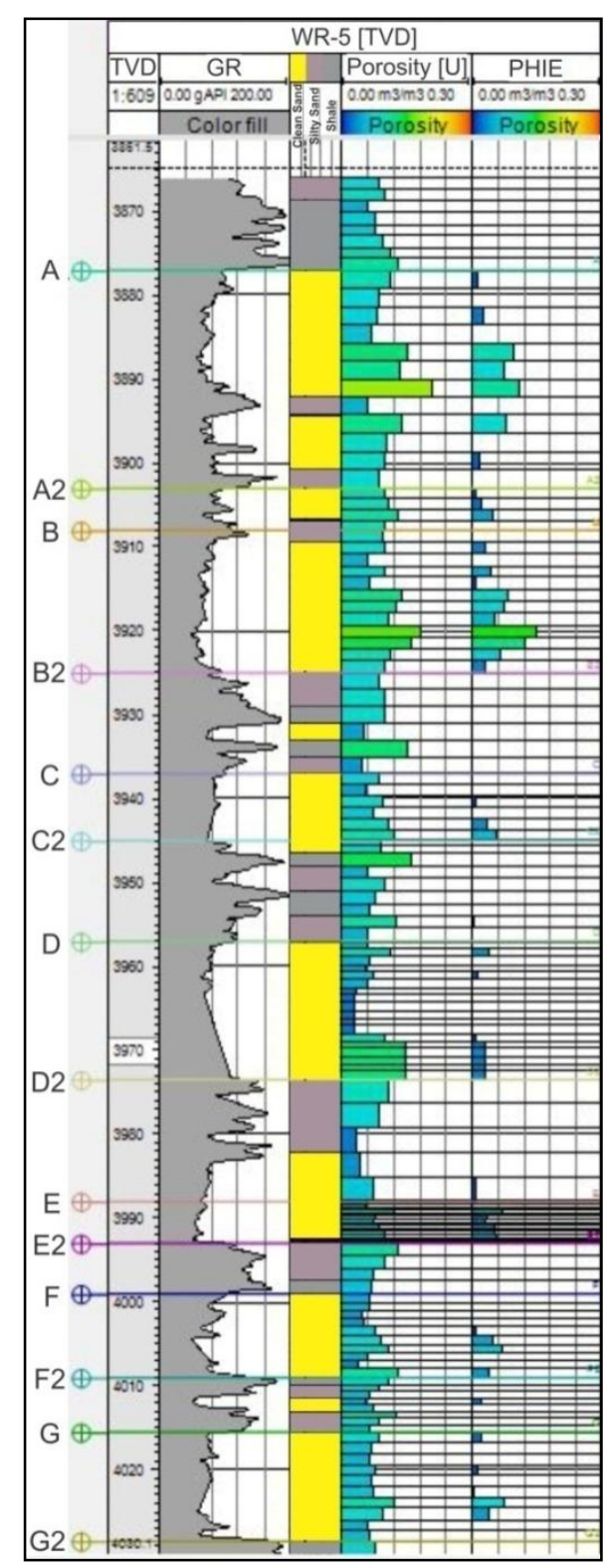

356 Fig. 11: Subdivision of the Willespie reservoir, in one of the wells (WR5) of the Whicher Range 357 Field, into various intervals (named as Latin letters) based on the main sandstone units which are 358 correlatable between the wells in the field. 


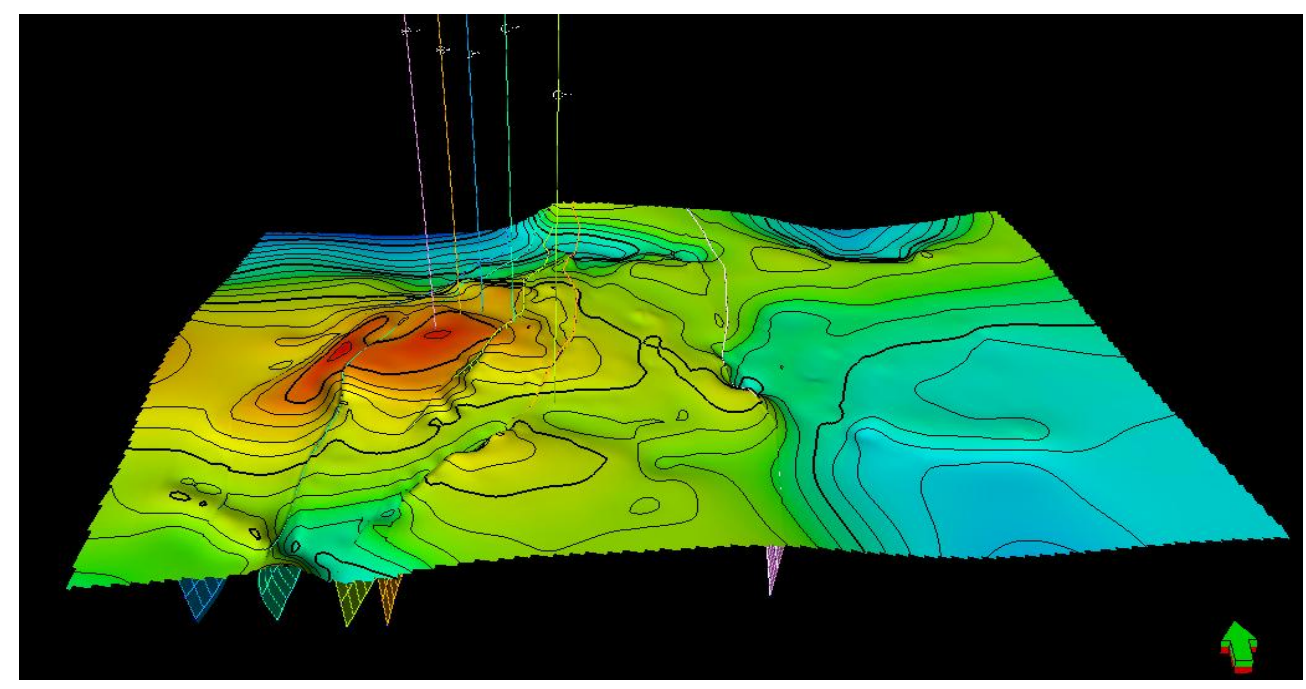

Fig.12: Structur map for the top of the Willespie Formation in the Whicher Range field.

\section{6.2. Property Modeling}

369 After structural modeling and establishing the initial reservoir skeleton, facies and 370 petrophysical characteristics of the reservoir sandstones based on the available data 371 from five wells were modeled to investigate their distribution in the field. 372 Variations in reservoir characteristics between the studied wells and throughout the 373 field can be modeled using statistical methods. Three main steps for property 374 modeling are described in below.

\section{$375 \quad 6.2 .1$. Scale-up}

376 Propagating the reservoir properties within the grid cells is done by which each cell 377 has a certain value for a specific parameter. But the grid cells often are much larger 378 than the sample density for that parameter, and the parameter values within the 379 cells must be scaled up before they can be entered into the grid. In this study, 380 "most of" approach has been applied for scaling up of facies. It was tried to 381 maintain the primary distribution function of well data. Histogram in Figure 13 382 demonstrates the upscaled result for facies in comparison with the original log. In 383 addition, for porosity upscaling which has been accomplished based on the 384 "Arithmetic" method, validation histogram is shown in Figure 14. 
1

4

387

388

389

390

391

392

393

394

23

$24 \quad 395$

26

27

28

29

30

31

32

33

34400

35

36

37

38

39

40

41403

42

$43 \quad 404$

44

45

46

47

48

49

$50 \quad 407$

51

52

53

54

55

56

57410

$\begin{array}{ll}58 & 411\end{array}$

59

60

61

62

63

64

65

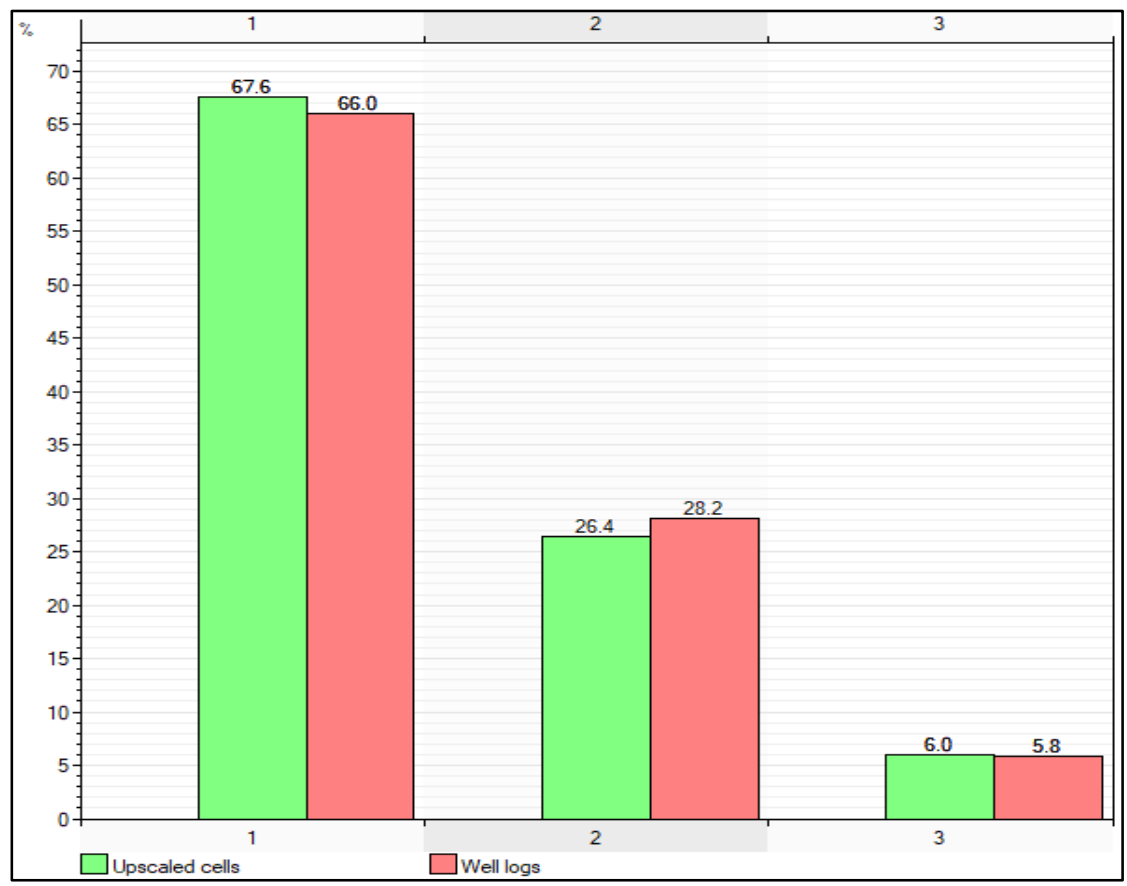

Fig. 13: Validation histogram showing the scaled up results for reservoir facies in comparison with the original well logs (numbers in x-axis are different facies: 1-clean sands, 2-silty sandstones, and 3-shale).

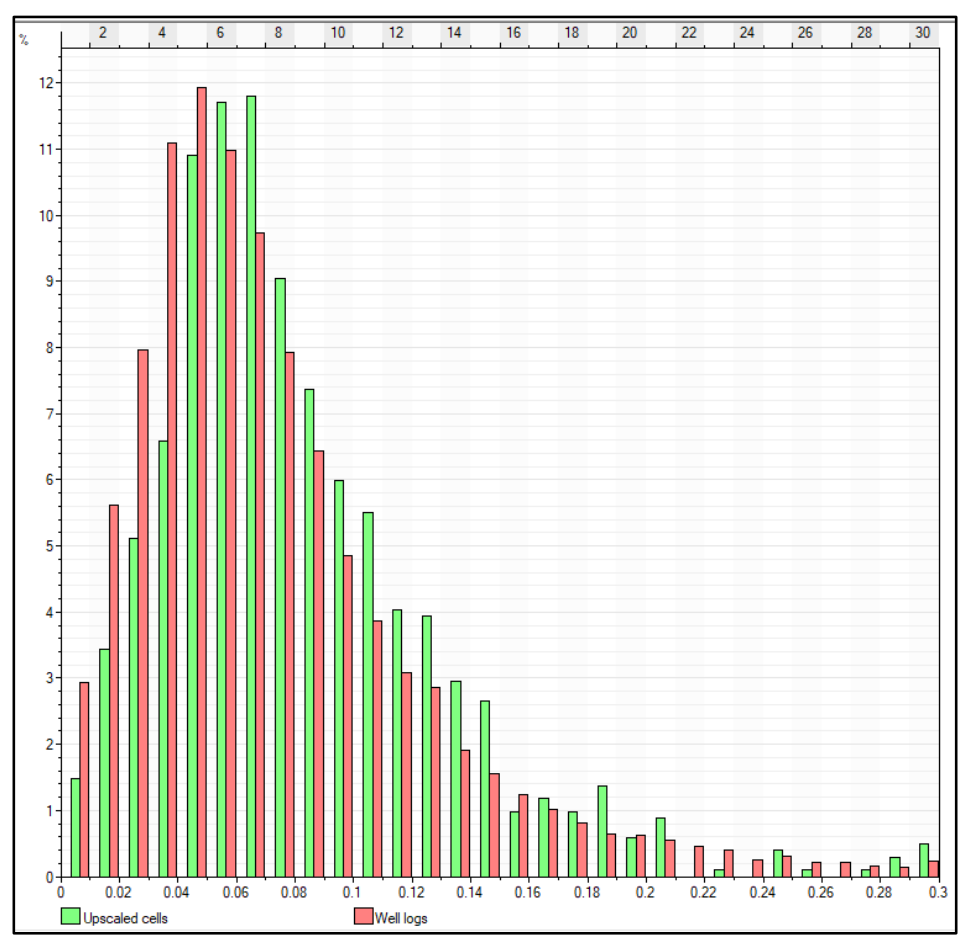

Fig. 14: Validation histogram showing the scaled up result for porosity in comparison with the original well $\log$. 
Data analysis process, as an important step in reservoir modeling, is used in controlling of data quality, investigation of their trend, and preparing the input data for facies and petrophysical modeling. In this study, variation trend of data in reservoir sandstones between the wells for each zone was investigated individually, by variogram analysis in three directions ( $\mathrm{x}$, yand $\mathrm{z}$ ). The main direction used in modeling was determined by variogram map derived from acoustic impedance (Fig. 15). In a variogram map, the direction of contour lines with the least variation or variance (east/northeast-west/south-west in this study) shows the most continuity of data in that direction which can be considered as the main direction of the variogram. Figure 16 shows examples of the variograms used for porosity modeling in three vertical, major and minor directions, in one of the reservoir zones.

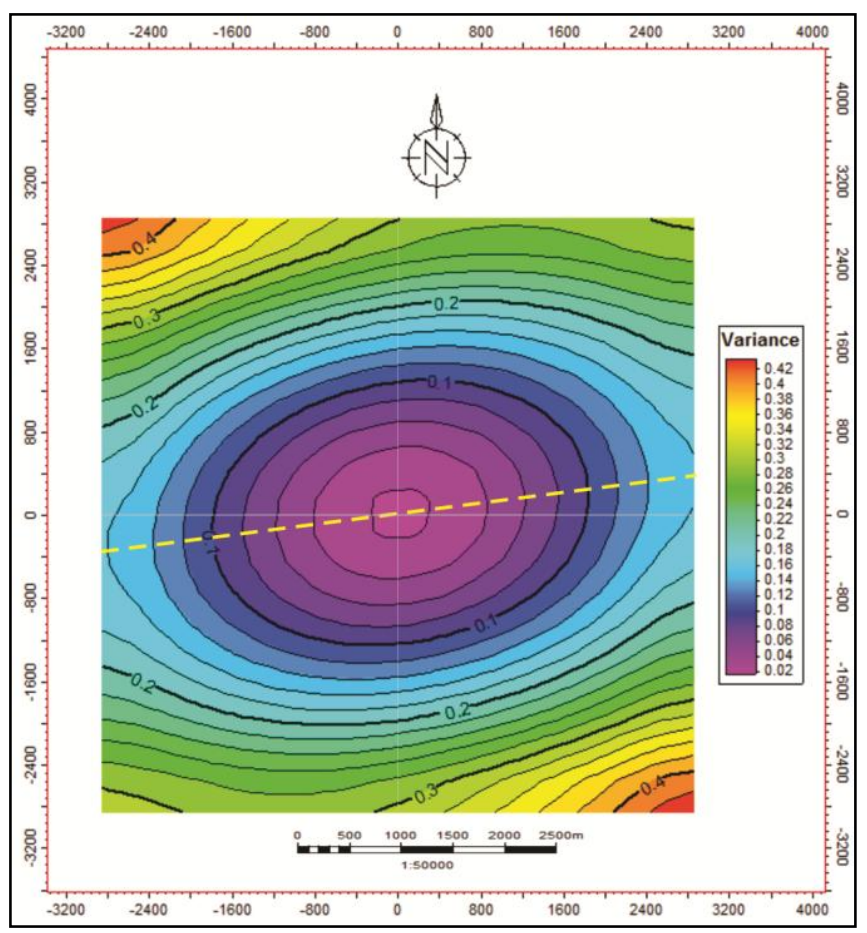

Fig. 15: Variogram map derived from acoustic impedance which is used to determine the main direction of variogram for modeling of reservoir sandstones in the studied field. 


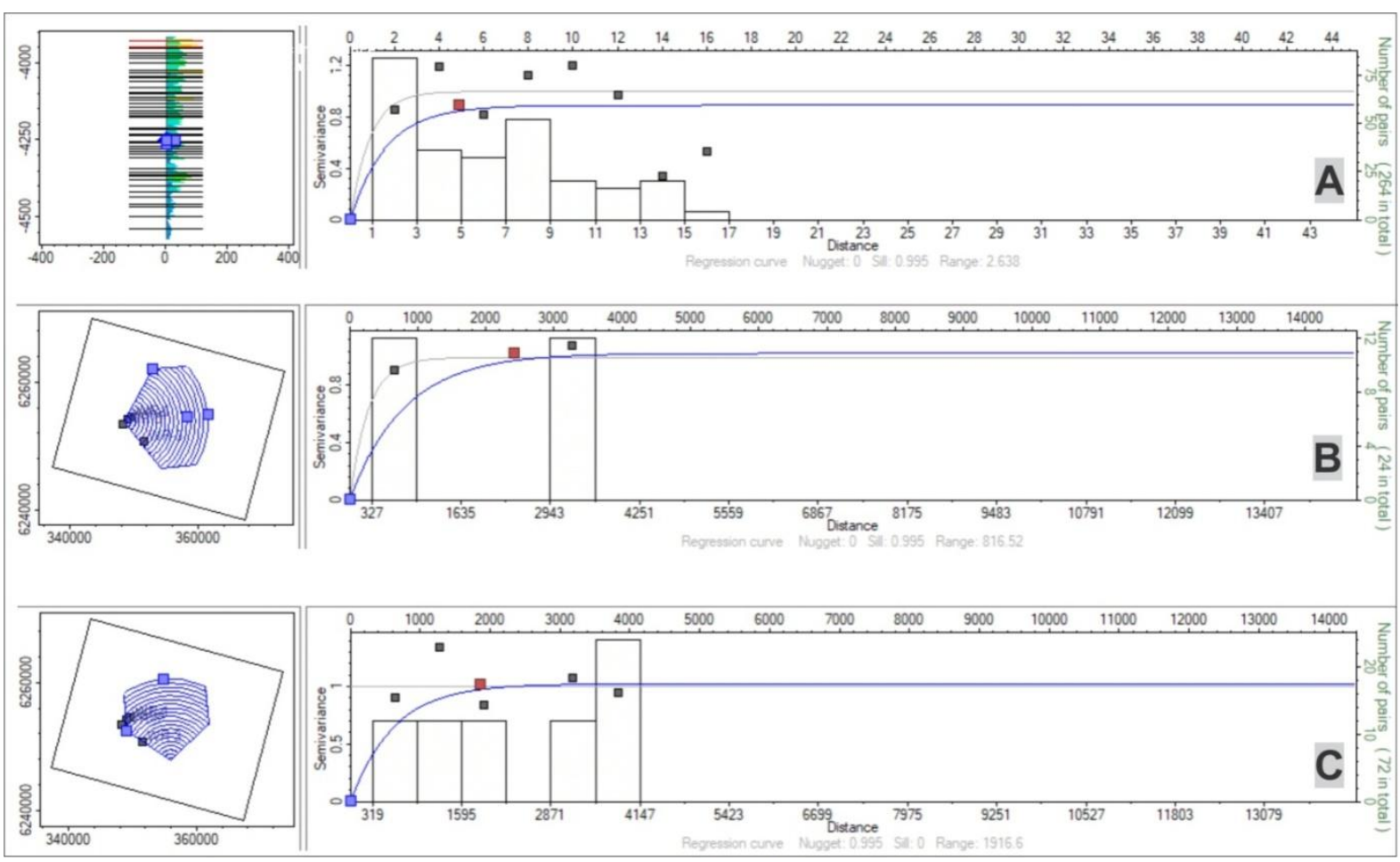

Fig. 16: Examples of the variograms in three vertical (A), major (B) and minor (C) directions used for porosity modeling in one of the reservoir units (zone A) of the Willespie Formation.

6.2.3. Modeling based on a suitable algorithm

In this study, reservoir modeling was constructed based on stochastic methods. In addition, according to the literature, stochastic methods produce more realistic results of reservoir properties comparing them to deterministic methods such as Kriging for which only one solution is generated.

\subsubsection{Facies modeling}

Spatial and geometrical distribution of facies is considered as an important agent of heterogeneity in clastic reservoirs (Yao and Chopra, 2000). So, facies modeling is the main stage in reservoir characterization and modeling of these reservoirs (Deutsch, 2002).Among different methods used in modeling of reservoir facies, Object-based and Pixel-based algorithms are two main methods. The most common Pixel-based algorithm is Sequential Indicator Simulation. This method is conditioned by variogram models that show the size and spatial distribution of 452 facies patterns. Three groups of depositional facies in the Whicher Range field are 453 coarse grained and clean sandstones $(\mathrm{GR}<80)$ of fluvial channel $(\mathrm{FA}-1)$ and 
crevasse splay (FA-3) as the main reservoir units, fine-grained and silty sandstones $(80<\mathrm{GR}<130)$ related to channel margin $(\mathrm{FA}-2)$ and crevasse splay (FA-3), and silty/shaly units (GR>130) of flood plain (FA-4) and paludal deposits (FA-5). A 457 specific digital code was assigned to each facies group for loading into the model 458 database. Data analysis was accomplished by their interpolation with a suitable 459 variogram model (spherical) in three spatial directions. Afterwards, facies model 460 using well data information and based on the Sequential Indicator Simulation was 461 extracted (Fig.17). According to the facies model, clean sandstone facies which 462 constitute the main reservoir units are interlayered with silty sandstones and shales, 463 and they show a significant change in thickness and their lateral and vertical 464 continuity throughout the reservoir interval.

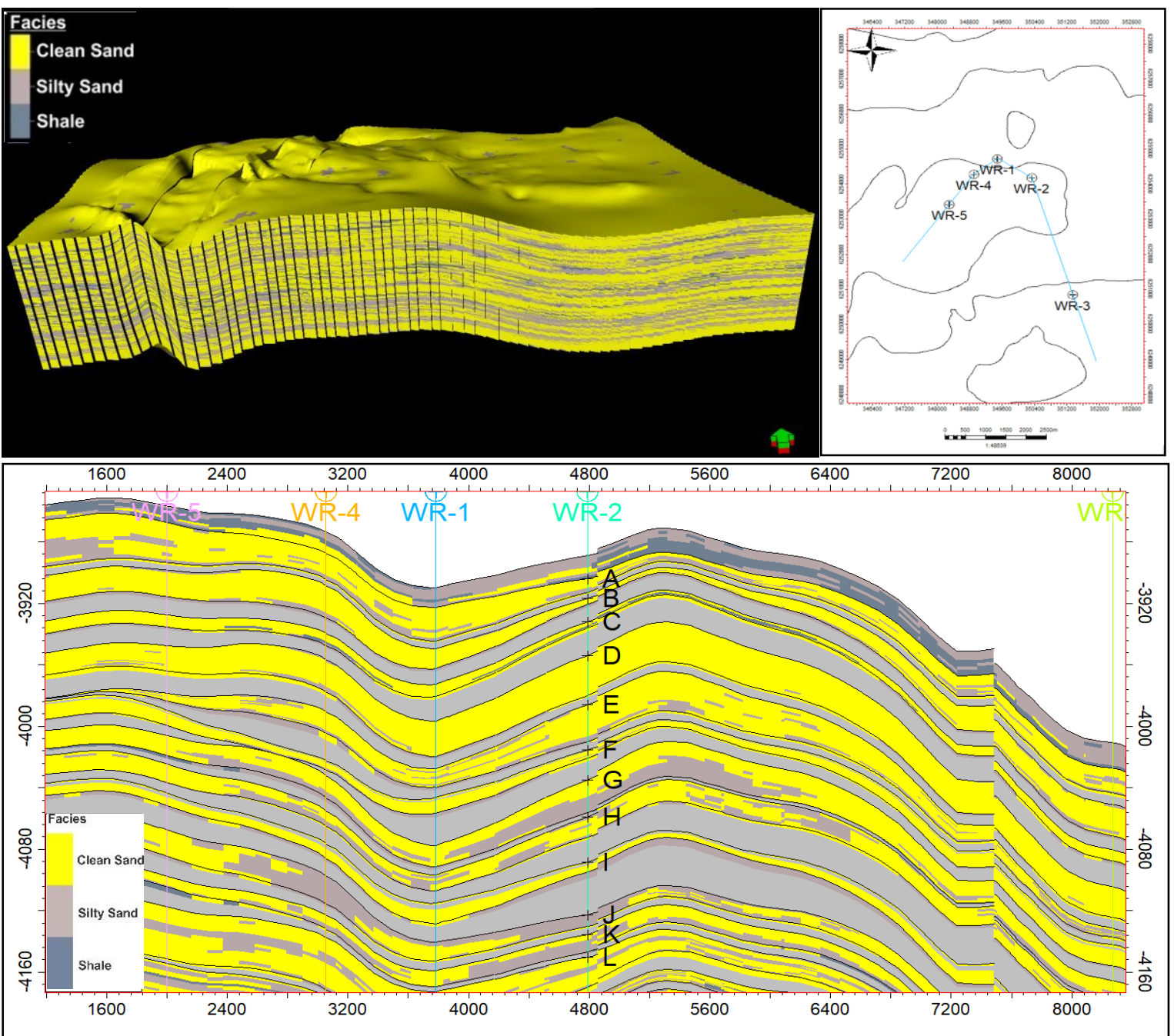

Fig. 17: 3D facies model and its cross-section along the wells of the Whicher Range field showing the distribution of reservoir facies (clean sand, silty sand and shale) in the field. 


\subsubsection{Porosity modeling}

Porosity model of reservoir sandstones in the Whicher Range field was created using Sequential Gaussian Simulation algorithm. Due to the clear and inverse relationship between the acoustic impedance (AI) and porosity (Fig. 18), it was used as the key control for modeling of porosity attribute. A model-based inversion approach was used to invert seismic data to acoustic impedance volume. After extraction of an optimal wavelet, AI was calculated through a deconvolution process. According to 3D view of acoustic impedance in Figure 19, this parameter generally shows a decreasing trend towards the upper part of the reservoir interval. Variation in AI can be interpreted based on depositional, diagenetic and petrophysical characteristics of the reservoir sandstones. As medium to coarse and very coarse sandstone facies with high porosity (10\% in average) are characterized by low values of AI, whereas fine to medium grained sandstones with low porosity (5\% in average) have high values of this parameter (Kadkhodaie-Ilkhchi et al., 2014). Accordingly, the co-kriging method was used to integrate the porosity and acoustic impedance data for reservoir modeling. In fact, co-kriging is a multivariate estimation method by which the spatial relationship between the primary (porosity) and secondary (AI) variables is analyzed, and the secondary variable is utilized in estimation to compensate the deficiency of primary variable.

Porosity was considered as the total and effective and it was analyzed by spherical variogram in three spatial directions. The extracted $3 \mathrm{D}$ models of total and effective porosity were shown in Figure 20 and Figure 21, respectively. According to the constructed models, total porosity shows significant increase towards the top of the formation. Such a result indicates porous zones have been concentrated in the upper parts of the reservoir. Although, effective porosity follows the same trend of total porosity, it has a sparse distribution within the reservoir interval. This is attributed to the effect of diagenetic processes (e.g., compaction, cementation and dissolution) on pore system properties, which is consistent with the tight nature of reservoir sandstones. It can be concluded that the initial sedimentary characteristics control the large-scale variations in reservoir properties including total porosity, and also the distribution of reservoir zones in the field. In contrast, diagenesis has the main control on effective porosity and internal reservoir heterogeneity. 
515

516

8

9

10

11

12

13

14

15

16

$17 \quad 520$

18

19

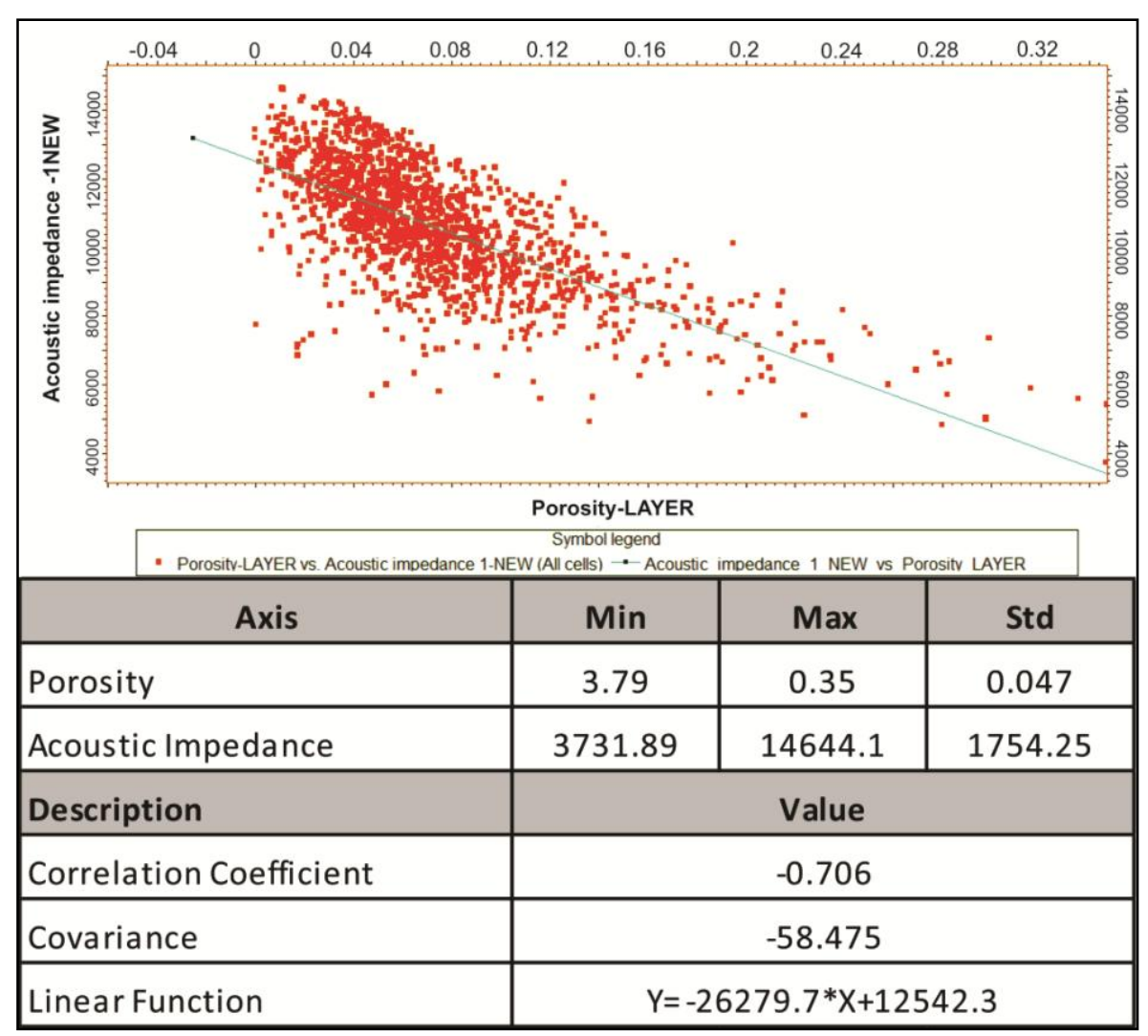

527 Fig. 18: Inverse relationship between acoustic impedance and porosity of reservoir sandstones in 528 the Whicher Range field. 
2

3

4540

541

8

9542

10

11

12

13

14

15

16

17

$18 \quad 546$

19

20

21

22

23

24

$25 \quad 549$

26

$27 \quad 550$

28

29

30

31

32

33

34553

35

36

37

38

39

40

41556

42

43

44

45

46

47

561

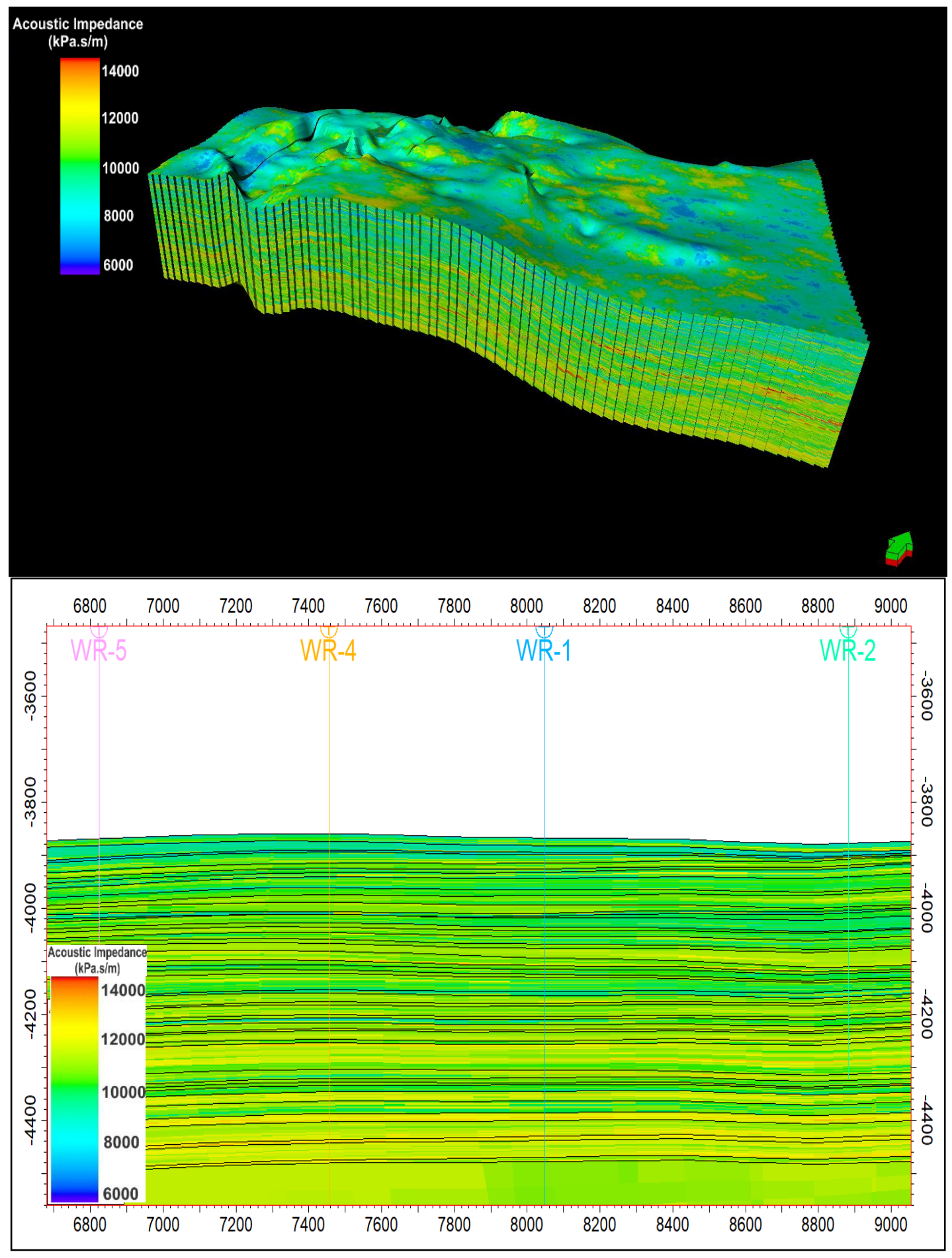

562 Fig. 19: 3-D view of acoustic impedance and its cross section along the Whicher Range wells shows a decreasing trend towards the upper part of the reservoir interval. 


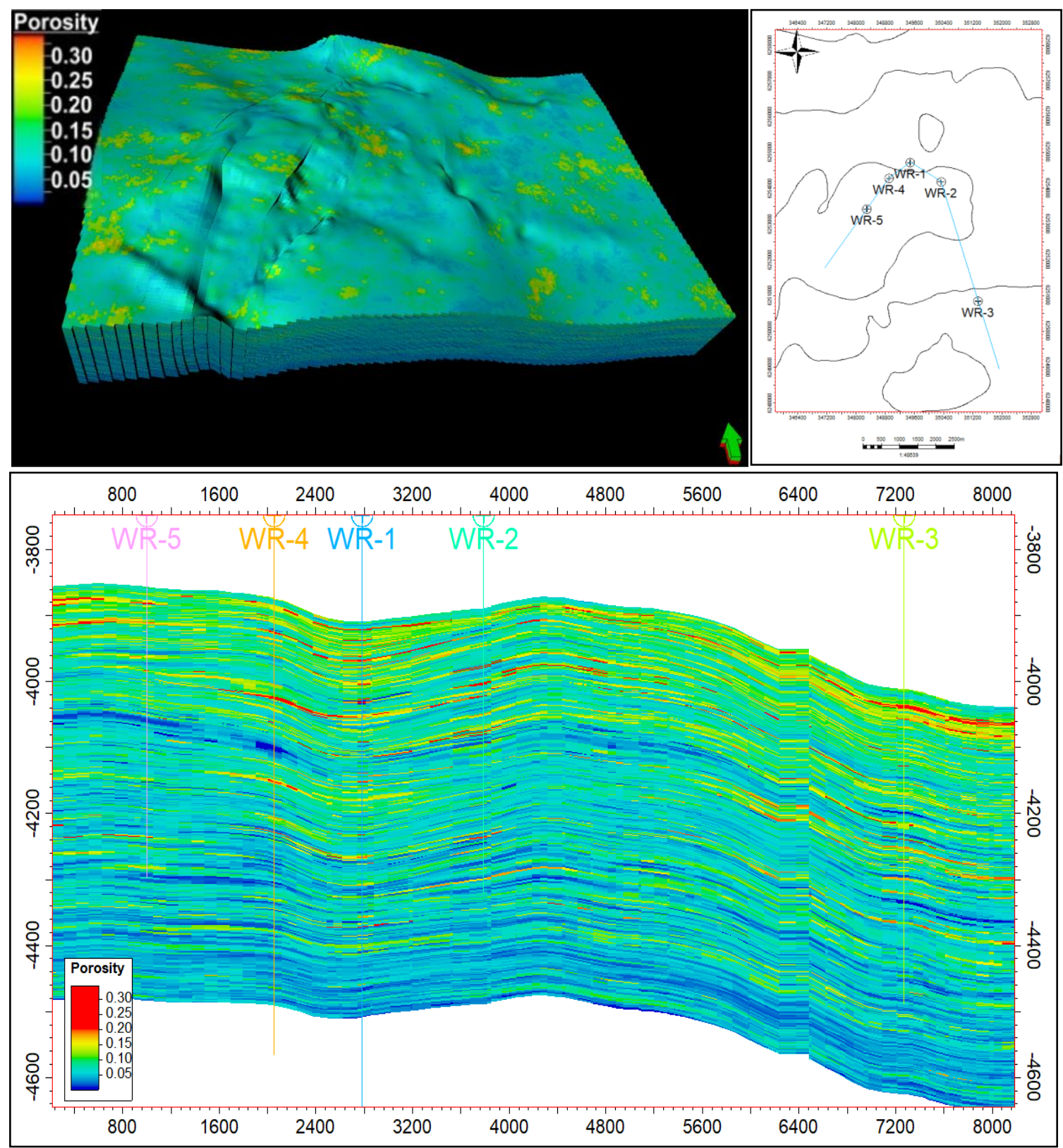

564

565 Fig. 20: 3D model of porosity and its cross section showing the distribution of total porosity in 566 the studied field. The general increasing trend of total porosity towards the upper parts of the 567 reservoir interval can be attributed to the accumulation of more porous and coarse grained 568 sandstone facies of fluvial channels in these parts of the reservoir. 

596

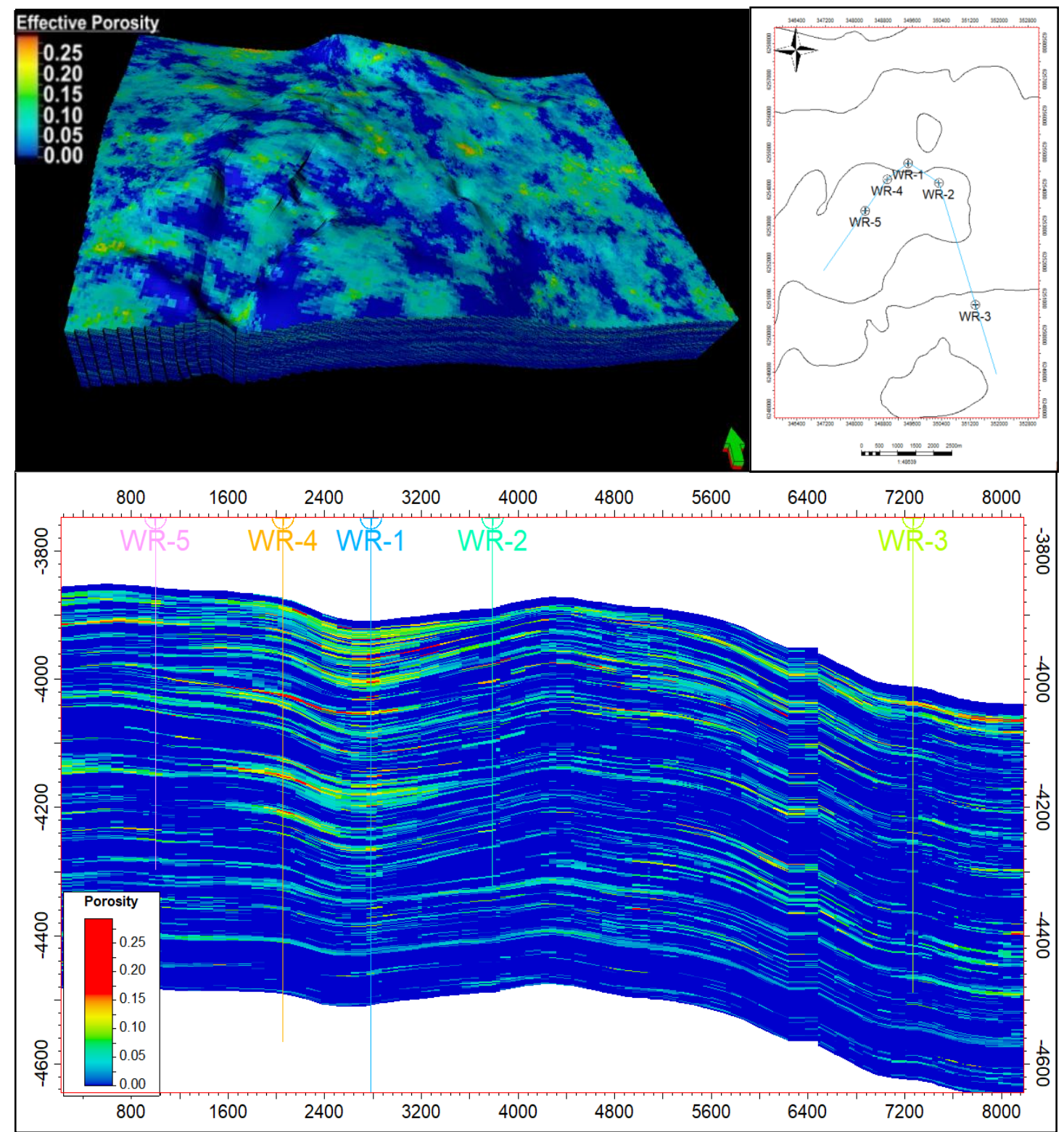

Fig. 21: 3D model of porosity and its cross section showing the distribution of effective porosity in the studied field. Increasing trend in effective porosity towards the upper parts of the reservoir interval is not clear as observed in total porosity trend. In addition, lateral increase of this parameter towards WR1 and WR4 wells is consistent with concentration of high porous and high permeable reservoir sandstones in their interval. 


\section{Results and discussion}

The results from facies and diagenesis analysis of tight sandstone facies and their effects on pore system properties indicate the complex effect of these parameters on reservoir heterogeneity reflecting in variability of reservoir properties throughout the field. High energy and coarse grained sandstone facies of the reservoir interval related to channel (FA-1) and crevasse splay (FA-3) subenvironments of meandering fluvial system contribute to main reservoir units with high reservoir quality in the field (Figs. $4 \& 5$ ).In contrast, fine grained and silty sandstone facies and coaly-slity shale interlayers of channel margin and flood plain sub-environments (FA-2, FA-4 and FA-5) under the effect of their initial depositional texture and also diagenesis are characterized by low reservoir quality, and have the potential to create barriers and baffles within the reservoir interval. In fact, variation in depositional environment of sandstone facies indicating by development of different facies association of specific sedimentary texture and structures has provided the main framework for development of reservoir zones in the field, and is considered as the main controlling factor on reservoir heterogeneity in the field scale. On the other hand, diagenesis by modification of primary depositional texture, composition and pore system properties has imported its effect on internal reservoir heterogeneity. According to the results from reservoir modeling in this study, most porous zones are coincident with coarse and high energy sandstone facies of fluvial channels that have been distributed as an individual or a set of stacked channels at the upper part of the formation (Figs. 17and 20). Although porosity shows a general increasing trend towards the upper sandstone units of the reservoir interval in five drilled wells of the Whicher Range field, this trend is not necessarily consistent with their thickness in the field (Fig. 22). This can also be seen in cross plot of Figure 23, where there is no clear relationship between porosity and thickness of sandstone units of the reservoir interval. This is attributed to heterolithic lithology of sandstone units, varying from very coarse to very fine and silty in size, and also the effect of diagenesis on pore system properties of the reservoir sandstones. Table 3 shows quantitative values of porosity and thickness of sandstone units as well as sand to shale thickness ratio in five wells of the field. Investigation of the reservoir facies along the Whicher Range wells, based on the porosity models, especially related to effective porosity (Figure 21) and also a 3D model of shale in the field (Fig. 24), indicates WR1 and 
WR4 wells have more porous and thicker zones than the other wells in their interval. This is consistent with the results from production tests and the results from previous studies (e.g., Kadkhodaie-Ilkhchi et al., 2013) mentioning high production and most promising sandstone zones in these wells. Also, thickness map of reservoir sandstones shows a decrease of the sand contribution towards the south-east parts of the field where WR2 and WR3 are situated (Fig. 25). This is also approved by an increase of sand to shale thickness ratio from WR2 and WR3 wells towards WR1, WR4 and WR5 wells. Fence diagrams of facies and porosity models of the reservoir sandstones are shown in Figure 26.

642 Faulted and anticlinal structure of the Whicher Range field, as mentioned early, is 643 related to tectonic and evolution history of the Perth Basin. According to Lasky et al (1993), the seismic data indicates that the Permian sequence thickens eastwards towards the Darling Fault and suggests that the fault controlled sedimentation during that time. Therefore, pore system of deeply buried $(\sim 4 \mathrm{~km})$ sandstone facies of the Willespie Formation have been initially affected by the basin subsidence along faults, as they are characterized by a compacted fabric. However, the effect of faulting on compartmentalization of the reservoir is not clear, and need investigation of more data and observation of reservoir data (production, pressure, etc.) and analysis of seismic sections of the field.

The uncertainty with the results derived from this work is not inevitable. As, the volume and particularly the quality of data available to construct the model, add a significant degree of uncertainty. However, the findings of this study provide a general view of the distribution of reservoir units and their porosity in the field which based on the horizontal drilling in upper parts of the reservoir interval especially in north-east section of the field is proposed. 


\begin{tabular}{|c|c|c|c|c|c|c|c|c|c|c|}
\hline \multirow{2}{*}{$\begin{array}{l}\text { Sand } \\
\text { Unit }\end{array}$} & \multicolumn{2}{|r|}{ WR1 } & \multicolumn{2}{|r|}{ WR2 } & \multicolumn{2}{|r|}{ WR3 } & \multicolumn{2}{|r|}{ WR4 } & \multicolumn{2}{|r|}{ WR5 } \\
\hline & $\begin{array}{l}\text { Phi } \\
(\%)\end{array}$ & Thickness(m) & $\begin{array}{l}\text { Phi } \\
(\%)\end{array}$ & Thickness(m) & $\begin{array}{l}\text { Phi } \\
(\%)\end{array}$ & Thickness(m) & $\begin{array}{l}\text { Phi } \\
(\%)\end{array}$ & Thickness(m) & $\begin{array}{l}\text { Phi } \\
(\%)\end{array}$ & Thickness(m) \\
\hline A & 12.97 & 22 & & 9 & 14.07 & 15 & 10.93 & 17 & 10.43 & 23 \\
\hline B & 12.29 & 13 & 5.59 & 4 & 10.63 & 20.5 & 11.03 & 21 & 11.31 & 17 \\
\hline C & 11.02 & 8 & 5.20 & 4 & 9.30 & 7 & 8.81 & 8 & 8.36 & 8 \\
\hline D & 12.03 & 23 & 9.62 & 25 & 9.19 & 20 & 9.08 & 21 & 6.87 & 16.5 \\
\hline $\mathbf{E}$ & 9.24 & 13 & 7.15 & 24 & 7.64 & 6 & 11.58 & 14 & 10.04 & 5 \\
\hline $\mathbf{F}$ & 14.03 & 10 & 7.06 & 5.5 & 9.52 & 13.5 & 15.98 & 6 & 6.51 & 10 \\
\hline G & 12.42 & 14 & 5.34 & 21.5 & 11.21 & 11.5 & 9.68 & 14.5 & 7.19 & 13 \\
\hline $\mathbf{H}$ & 7.42 & 10.5 & 10.69 & 13.5 & 8.15 & 11 & 10.16 & 10 & 10.13 & 12 \\
\hline $\mathbf{I}$ & 7.11 & 12 & 9.40 & 6.5 & 9.79 & 19.5 & 5.38 & 9.5 & 8.83 & 8 \\
\hline J & 10.02 & 12 & 7.96 & 7.5 & 12.81 & 10 & 4.71 & 18 & 5.84 & 17 \\
\hline $\mathbf{K}$ & 9.85 & 10 & 5.45 & 11.5 & 9.06 & 8 & 10.12 & 9 & 5.22 & 7 \\
\hline $\mathbf{L}$ & 9.97 & 38 & 7.06 & 19.5 & 6.63 & 10 & 9.01 & 34 & 6.89 & 34 \\
\hline $\mathbf{M}$ & 7.76 & 19 & 6.05 & 9 & 6.88 & 28 & 5.84 & 17 & 5.62 & 22 \\
\hline $\mathbf{N}$ & 5.15 & 21 & 6.44 & 22 & 4.30 & 15.5 & 9.55 & 19 & 5.72 & 20 \\
\hline 0 & 10.33 & 9 & 7.58 & 9 & 9.11 & 16 & 8.12 & 9 & 5.63 & 7 \\
\hline $\mathbf{P}$ & 5.06 & 6 & 5.67 & 4.5 & 6.39 & 12.5 & 6.86 & 4 & 6.92 & 4 \\
\hline $\mathbf{Q}$ & 9.91 & 12 & 8.45 & 9 & & 6 & 2.67 & 7 & 6.60 & 11 \\
\hline $\mathbf{R}$ & 6.11 & 10 & \multicolumn{2}{|c|}{ Sand/Shale: 1.12} & & 14.5 & 8.54 & 17 & \multicolumn{2}{|c|}{ Sand/Shale: 1.29} \\
\hline $\mathbf{S}$ & 9.22 & 3 & & & \multicolumn{2}{|c|}{ Sand/Shale: 1.16} & 6.96 & 5.5 & & \\
\hline $\mathbf{T}$ & 7.12 & 18.5 & & & & & 3.64 & 18 & & \\
\hline $\mathbf{U}$ & 4.04 & 15.5 & & & & & 5.31 & 15 & & \\
\hline V & 2.41 & 8.5 & & & & & 3.52 & 7 & & \\
\hline \multirow[t]{2}{*}{$\mathbf{W}$} & 3.20 & 10 & & & & & 5.85 & 6.5 & & \\
\hline & \multicolumn{2}{|c|}{ Sand/Shale: 1.22} & & & & & \multicolumn{2}{|c|}{ Sand/Shale: 1.30} & & \\
\hline
\end{tabular}




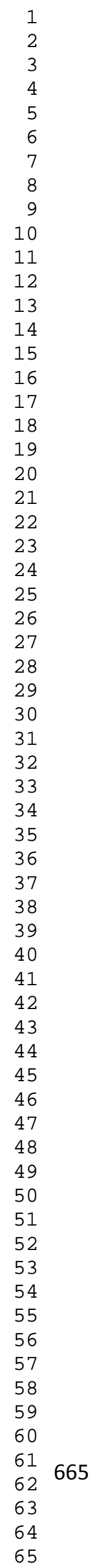

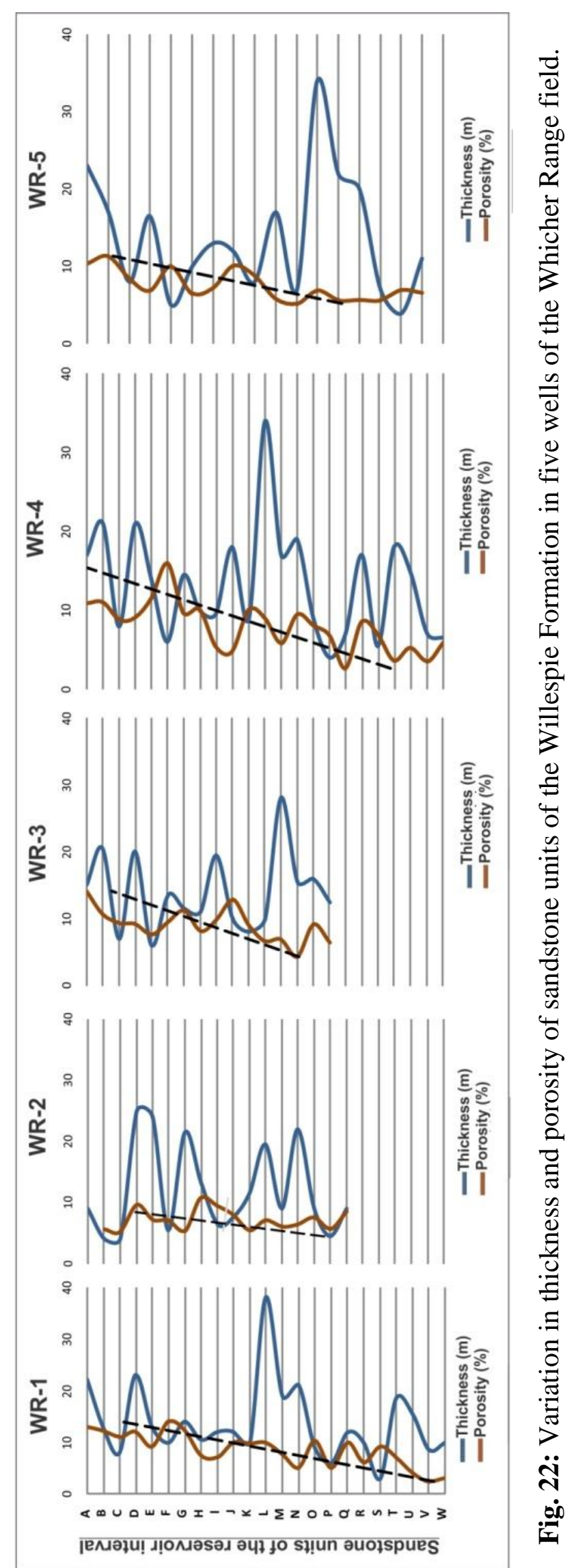




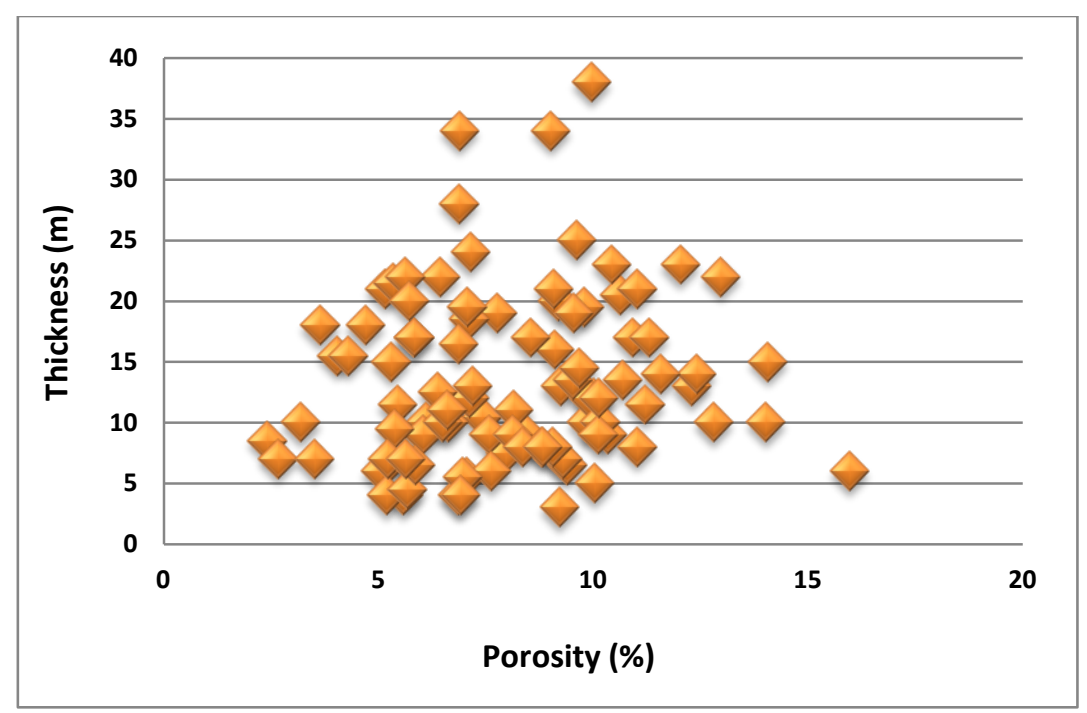

667 Fig. 23: Cross plot of porosity and thickness of sandstone units in the field. According to this 668 plot, there is no clear relationship between these parameters.
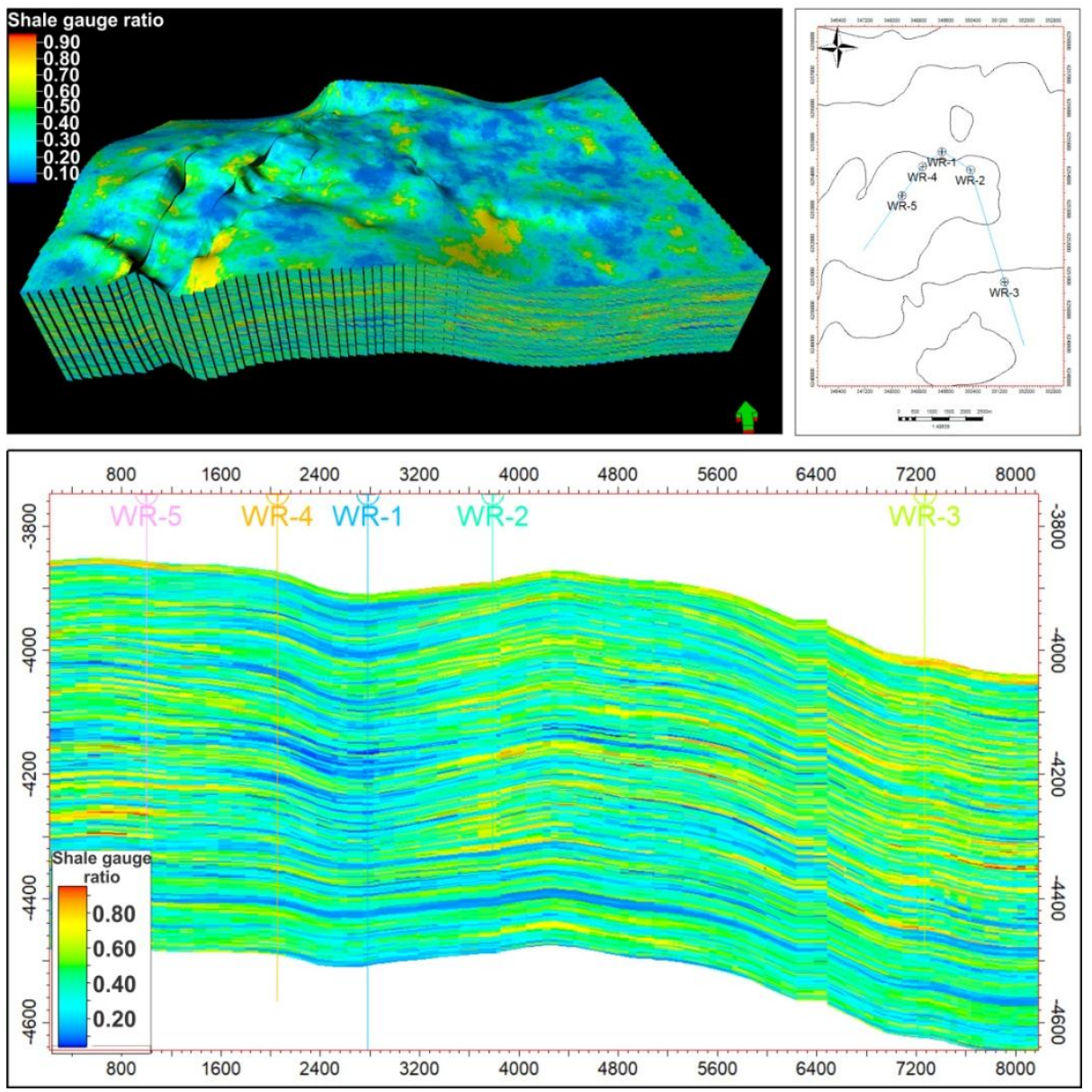

682 Fig. 24: Spatial model of sandstones and its cross section showing the distribution of shale in 683 the studied field. 


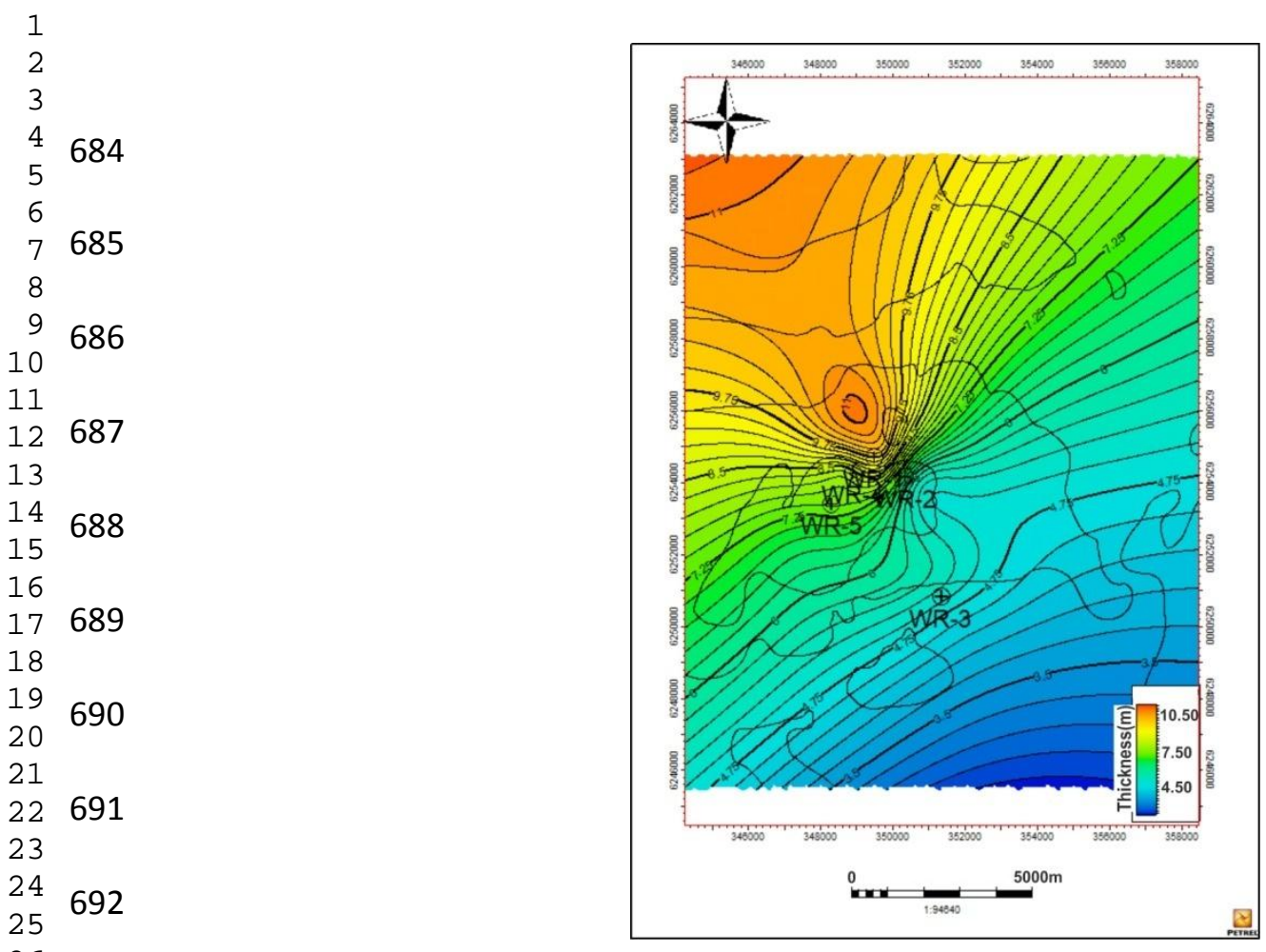

Fig. 25: Thickness map of sand in the Whicher Range Field.
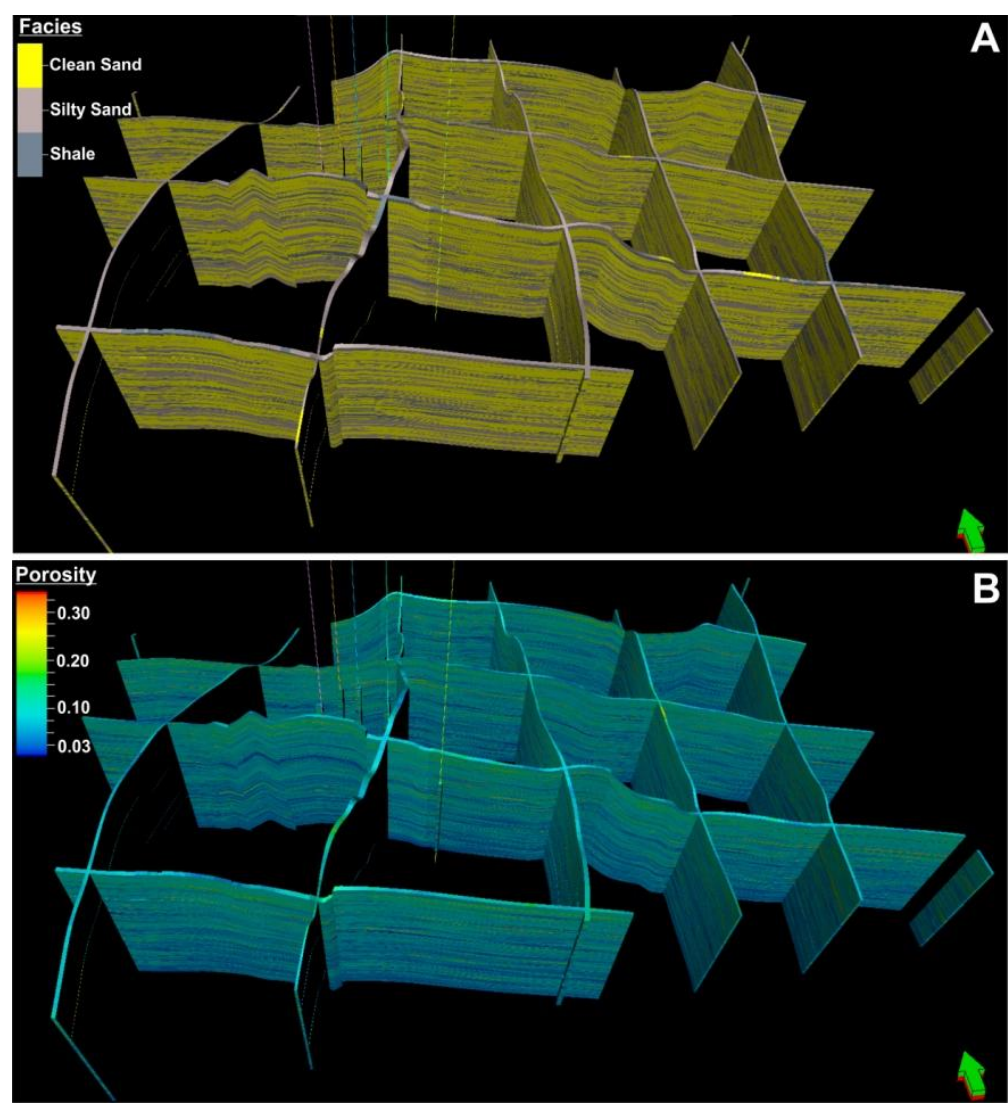


\section{Conclusion}

Tight sandstone facies of the late Permian Willespie Formation ofthe Whicher Range field show some degrees of heterogeneity and complexity in pore system properties and reservoir characteristics related to sedimentary texture and diagenetic features. These facies wihich have been deposited in a meandering river system can be categorized in five facies associations (FA1 to FA5) related to the channel, crevasse splay, levee, floodplain and paludal/lacustrine deposits. Based on core poroperm data analysis, medium to coarse grained facies of fluvial channel and crevesse spalygenerally show higher reservoir quality than fine grained and silty-shaly facies of flood plain and lacustrine subenvironments. In addition, diagenetic processes including compaction, cementation (authigenic clays, calcite and siliceous) and dissolution have severely modified pore system propeties of reservoir sandstones, although their effects, depending on primary depositional texture and mineralogical composition of reservoir facies, is different. Characterization of these sandstones in terms of three-dimensional facies and porosity modeling demonstrates different scales of heterogeneity within the reservoir interval of the field. In a large (field) scale, depositional environment of the reservoir facies has the main control on the distribution of reservoir zones in the field. As, most porous zones are coincident with coarse and high energy sandstone facies of fluvial channels that have been distributed as an individual or a set of stacked channels at the upper part of the formation.In contrast, diagenesis, in smaller (pore) scale, by modification of primary depositional texture, composition and pore system properties of the reservoir facies has imported its effect on internal reservoir heterogeneity. Unraveling the reservoir heterogeneity, derived from this study, demonstrates that the vertical and lateral variability in reservoir properties follows distinctive trends within the reservoir interval and can be considered in development and production strategies of the field such as horizontal drilling in upper parts of the formation.

\section{Acknowledgements}

The authors would like to appreciate the Curtin University of Technology, Department of Petroleum Engineering, Whicher Range Energy, and Department of Mines and Petroleum (WAPIMS) for providing necessary data to perform this study and to permit us to publish this paper. 


\section{References}

Albertão, G.A., Bampi, D., Schwedersky, G., 2001. Reservoir quality modeling and streamline simulation: An application in Campos Basin, Brazil. SPE 71353.

Caers, J., 2000. Adding local accuracy to direct sequential simulation. Math. Geol. 32 (7), 815850.

Ciftci, B., 2012. First order reservoir modeling of the Whicher Range Field tight gas sands. Whicher Range tight gas sands study, Western Australian Energy Research Alliance, Report 112, 288-307.

Crostella, A., Backhouse, J., 2000. Geology and petroleum exploration in the central and southern Perth Basin: Western Australia Geological Survey, Report 57, 85 pp.

Deutsch, C.V., 2002. Geostatistical Reservoir Modeling. Oxford University Press Inc., Oxford, UK, p. 385.

Deutsch, C.V., Journel, A., 1998. GSLIB: Geostatistical Software Library and User's Guide, second ed. Oxford University Press, New York, p. 369.

Dou, W., Liu, L., Wu, K., Xu, Z., Liu, X.,Feng, X., 2018. Diagenetic heterogeneity, pore throats characteristic and their effects on reservoir quality of the Upper Triassic tight sandstones of Yanchang Formation in Ordos Basin, China. Marine and Petroleum Geology, Volume 98, 243-257.

Du, S., Pang, S., Shi, Y., 2018. Quantitative characterization on the microscopic pore heterogeneity of tight oil sandstone reservoir by considering both the resolution and representativeness. Journal of Petroleum Science and Engineering 169, 388-392.

Dubrule, O., 2003. Geostatistic for Seismic Data Integration in Earth Models. SEG, EAGE, Tulsa, USA, p. 273.

Folk, R.L., Andrews, P.B., Lewis, D.W., 1970. Detrital sedimentary rock classification and nomenclature for use in New Zealand. New Zealand Journal of Geology and Geophysics 13, 937-968.

Hall, P. B., Kneale, R. L., 1992. Perth Basin rejuvenated. Australian Petroleum Exploration Association Journal 32 (1), 33-43.

Hsieh, A.I., Allen, D.M., MacEachern, J.A., 2017. Upscaling permeability for reservoir-scale modeling in bioturbated, heterogeneous tight siliciclastic reservoirs: Lower Cretaceous Viking 
Huang, W., Lu, S.,Hersi, O.S., Wang, M., Deng, S., Lu, R., 2017. Reservoir spaces in tight sandstones: Classification, fractal characters, and heterogeneity. Journal of Natural Gas Science and Engineering 46, 80-92.

Iasky, R.P., Young, R. A., Middleton M.F., 1991. Structural Study of the Southern Perth Basin by Geophysical Methods, exploration Geophysics, V 22, p 199-206.

Journel, A.G., Alabert, F.G., 1988. Focusing on spatial connectivity of extreme-valued attributes: Stochastic Indicator Models of Reservoir Heterogeneities. SPE Paper 18234.

Kadkhodaie-Ilkhchi, R., Rezaee R., Moussavi-Harami R., Nabi-Bidhendi, M., KadkhodaieIlkhchi, A., 2014. Seismic inversion and attributes analysis for porosity evaluation of the tight gas sandstones of the Whicher Range field in the Perth Basin, Western Australia. Journal of Natural Gas Science and Engineering 21, 1073-1083.

Kadkhodaie-Ilkhchi, R., Moussavi-Harami R., Rezaee R., Kadkhodaie-Ilkhchi, A., 2014. Analysis of the reservoir electrofacies in the framework of hydraulic flow units in the Whicher Range Field, Perth Basin, Western Australia. Journal of Petroleum Science and Engineering 111, 106-120.

Kiaei, H., Sharghi, Y., Kadkhodaiellkhchi, A., Naderi, M., 2015. 3D modeling of reservoir electrofacies using integration clustering and geostatistic method in central field of Persian Gulf. Journal of Petroleum Science and Engineering 135, 152-160.

Kulga, B., Artun, E., Ertekin, T., 2018. Characterization of tight-gas sand reservoirs from horizontal-well performance data using an inverse neural network. Journal of Natural Gas Science and Engineering 59, 35-46. doi:10.1016/j.jngse.2018.08.017.

Lai, J., Wang, G., Wang, S., Cao, J., Li, M., Pang, X., Zhou, Z., Fan, X., Dai, Q., Yang, L., He, Z., Qin, Z., 2018. Review of diagenetic facies in tight sandstones: Diagenesis, diagenetic minerals, and prediction via well logs. Earth-Science Reviews 185, 234-258. doi:10.1016/j.earscirev.2018.06.009.

Lai, J., Wang, G., Wang, Z., Chen, J., Pang, X., Wang, S., Zhou, Z., He, Z., Qin, Z., Fan, X., 2017. A review on pore structure characterization in tight sandstones. Earth-Science Reviews 177, 436-457. doi:10.1016/j.earscirev.2017.12.003. 
Li, Z., Wu, S., Xia, D., Zhang, X., Huang, M., Diagenetic alterations and reservoir heterogeneity within the deposition al facies: A case study from distributary-channel belt sandstone of Upper Triassic Yanchang Formation reservoirs (Ordos Basin, China). Marine and Petroleum Geology 86, 950-971.

Mahgoub, M.I., Padmanabhan, E., Abdullatif, O.M., 2018. Facies and porosity 3D models constrained by stochastic seismic inversion to delineate Paleocene fluvial/lacustrine reservoirs in Melut Rift Basin, Sudan. Marine and Petroleum Geology 98, 79-96.

Marshall, J.F., Lee, C.S., Ramsay, D.C., Moore, A.M.G., 1989. Tectonic controls on sedimentation and maturation in the offshore north Perth Basin. Australian Society of Exploration Geophysicists Journal 29, 450-465.

Martinius, A.W., Fustic, M., Garner, D.L., Jablonski, B.V.J., Strobl, R.S., MacEachern, J.A., Dashtgard, S.E., 2017. Reservoir characterization and multiscale heterogeneity mode ling of inclined heterolithic strata for bitumen-production forecasting, McMurray Formation, Corner, Alberta, Canada. Marine and Petroleum Geology 82, 336-361.

Miall, A.D., 2006. The Geology of Filuvial Deposits: Sedimentary Facies, Basin Analysis, and Petroleum Geology, Springer-Verlag, ${ }^{4}$ th printing, New York,582 pp.

Mory, A. J., Iasky, R. P., 1996. Stratigraphy and structure of the onshore northern Perth basin, Western Australia: Western Australia Geological Survey, Report No. 46, 101 pp.

Oluwadebi, A.G., Taylor, K.G., Patrick J. Dowey, P.J., 2018. Diagenetic controls on the reservoir quality of the tight gas Collyhurst sandstone formation, lower Permian, east Irish Sea basin, United Kingdom. Sedimentary Geology 371, 55-74. doi:10.1016/j.sedgeo.2018.04.006.

Orsini, C., Rezaee, R., 2012. Depositional Systems Sequence Stratigraphy Frameworks \& Geological Modelling of Fluvial Bodies. Geological Survey of Western Australia, Report 112, $405 \mathrm{p}$.

Owad-Jones, D., Ellis, G., 2000. Atlas of petroleum fields, onshore Perth Basin, Petroleum Division, DMEWA1, 122.

Pennezoil Far East Company, 1998. A review of the reservoir properties of the Sue Coal Measures in the Whicher Range Field area, South Perth Basin, Western Australia. 81 pp.

Pennezoil Far East Company, 1998. A review of the reservoir properties of the Sue Coal Measures in the Whicher Range Field area, South Perth Basin, Western Australia. 81 pp. 
Playford, P.E., Cockbain, A.E., Low, G.H., 1976. Geology of the Perth Basin, Western Australia. Geological Survey of Western Australia Bulletin 124, 311 pp.

Quaife, P., Rosser, J., Pagnozzi, S., 1994. The structural architecture and stratigraphy of the offshore northern Perth Basin, Western Australia. In: Purcell, P.G, Purcell, R.R. (Eds.), The Sedimentary Basins of Western Australia. Proceedings of Petroleum Exploration Society of Australia Symposium. Petroleum Exploration Society of Australia, 811-822.

Rezaee, R., Saeedi, A., Clennell, B., 2012. Tight gas sands permeability estimation from mercury injection capillary pressure and nuclear magnetic resonance data. Journal of Petroleum Science and Engineering 88-89, 92-99.

Sharifzadeh, A., 2008. Tight-Gas Resources in the Northern Perth Basin, Petroleum W.A. Magazine, 41-44.

Tobin, R.C., Mcclain, T., Lieber, R.B., Ozkan, A., Banfield, L.A., Marchand, A. M. E., McRae, L.E., 2010. Reservoir quality modeling of tight-gas sands in Wamsutter filed: Integration of diagenesis, petroleum systems, and production data. American Association of Petroleum Geologists Bulletin 94(8), 1229-1266.

Stroker, T.M., Harris, N. B., Elliott, W.C., Wampler, J.M., 2013. Diagenesis of a tight gas sand reservoir: Upper Cretaceous Mesaverde Group, Piceance Basin, Colorado. Marine and Petroleum Geology 40, 48-68.

Weber, K.J., 1980. Influence in fluid flow of common sedimentary structures in sand bodies. SPE Annual Technical Conference and Exhibition, Texas, USA, 21-24 September, SPE 9247.

Wei, W., Zhu, X., Meng, Y., Xiao, L., Xue, M., Wang, J., 2016. Porosity model and its application in tight gas sandstone reservoir in the southern part of West Depression, Liaohe Basin, China. Journal of Petroleum Science and Engineering 141, 24-37.

Xiao, D., Jiang, S., Thul, D., Lu, S., Zhang, L., Li, B., 2018. Impacts of clay on pore structure, storage and percolation of tight sandstones from the Songliao Basin, China: Implications for genetic classification of tight sandstone reservoirs. Fuel 211, 390-404.

Yang, H., Fu, J., Wei, X., Liu, X., 2008. Sulige field in the Ordos Basin: Geological setting, field discovery and tight gas reservoirs. Marine and Petroleum Geology 25, 387-400. 
Yao, T., Anil Chopra, A., 2000. Integration of seismic attribute map into 3D facies modeling.Journal of Petroleum Science and Engineering 27, 69-84.

Zhang, Li., Bai, G., Luo, X., Ma, X., Chen, M., Wu, M., Yang, W., 2009. Diagenetic history of tight sandstones and gas entrapment in the Yulin Gas Field in the central area of the Ordos Basin, China. Marine and Petroleum Geology 26, 974-989.

Zhi, G., Longde, S., Ailin, J.,Tao, L., 3-D geological modeling for tight sand gas reservoir of braided river facies. Petroleum Exploration and Development, 42(1), 83-91.

Zou, C., Zhu, R., Liu, K., Su, L., Bai, B., Zhang, X., Yuan, X., Wang, J., 2012. Tight gas sandstone reservoirs in China: characteristics and recognition criteria. Journal of Petroleum Science and Engineering 88-89, 82-91. 


\title{
Unraveling the reservoir heterogeneity of the tight gas sandstones using the porosity conditioned facies modeling in the Whicher Range field, Perth Basin, Western Australia
}

${\text { Rahim Kadkhodaie-Ilkhchi }{ }^{1 *} \text {, Reza Rezaee }}^{2}$, Ali Kadkhodaie ${ }^{1}$, Vali Mehdipour ${ }^{3}$

1. Earth Science Department, Faculty of Natural Science, Tabriz, Iran

2. Department of Petroleum Engineering, Curtin University, Perth, Australia

3. DanaEnergy Company, Tehran, Iran

*Corresponding author: Tel./fax: +98 9128457310

E-mail: rahimkadkhodaee2005@gmail.com, rahimkadkhodaee2005@yahoo.com (R. Kadkhodaie-

Ilkhchi); r.rezaee@curtin.edu.au (R. Rezaee); kadkhodaie_ali@tabrizu.ac.ir (A. Kadkhodaie -Ilkhchi);

mehdipour.vali@gmail.com (V. Mehdipour)

\begin{abstract}
Tight sandstones of the late Permian Willespie Formation constitute an important reservoir rock in the Whicher Range gas field of the Perth Basin. The sandstones under the effect of sedimentary conditions and diagenesis show some degree of heterogeneity reflecting in reservoir properties and production history. The Willespie Formation consists of fine to coarse-grained and gravelly feldspathic sandstones intercalated with shale, siltstone and coal, deposited in a meandering river system. Different diagenetic processes including compaction, cementation (authigenic clays, calcite and siliceous) and dissolution have severely affected the pore system properties of the reservoir sandstones, as they are considered as tight sandstones. Three-dimensional modeling of facies and porosity of reservoir sandstones in the field indicate a close relationship between sedimentary characteristics and reservoir properties. Based on the extracted models, most of the porous zones are related to the clean and coarse sandstones of the fluvial channels accumulating in the upper parts of the reservoir. In addition, lateral and vertical variations in thickness and continuity of reservoir units in the field are mainly controlled by facies and sedimentary environment characteristics. In fact, initial sedimentary characteristics have the main impact on the distribution of reservoir zones in the field and large-scale reservoir heterogeneity which has been enhanced by the effect of diagenetic processes on the pore system properties in next stages. The results derived from this study can be considered for optimizing exploration and development targets of the field.
\end{abstract}


Keywords: Tight sandstones, modeling, sedimentary characteristics, diagenesis, reservoir heterogeneity

\section{Introduction}

Prediction and knowledge of the spatial distribution of lithology and petrophysical characteristics of the reservoir are essential for development targets, production and reserve estimation of the field (Al-Khalifah and Makkawi, 2002; Izadi and Ghalambor, 2012). Nowadays, it is usual to use geostatistical models to investigate the distribution of reservoir characteristics in the hydrocarbon fields. In fact, geostatistics is a tool by which the geologists and engineers can analyze the data and use the results for prediction and modeling of the reservoir (Al-Khalifah and Makkawi, 2002). Modeling of facies and reservoir attitudes is fundamental to study the distribution of production zones and to clarify the internal heterogeneity of the reservoir (e.g., Desbois et al., 2011; Qiulin et al., 2011; Tobin et al., 2010). Tight gas sandstones are considered as a part of unconventional reservoirs in the world and especially in Australia. Perth Basin in the south-west of Western Australia contributes to a specific part of tight gas sandstone reservoirs. Tight reservoir sandstones of the Whicher Range field in the Perth Basin, the target of this study, under the effect of primary sedimentary characteristics and diagenetic processes, show some complexities in pore system and reservoir properties affecting their production behavior in the field. Thus, the study of these sandstones in the framework of a 3D model of facies and petrophysical properties can efficiently provide a comprehensive sense of the distribution of the reservoir zones in the field and identification the main factors controlling the reservoir quality.

\section{Geology, tectonic setting and stratigraphy}

Perth Basin is considered as a rift basin with north-south trending which has been located on the western border of Western Australia and adjacent to Yilgarn Craton (Fig. 1A). Darling Fault in the eastern part of the basin has exerted significant control on its formation. In fact, the basin formation and evolution is related to two main tectonic phases with tension system. The first phase which has been occurred in the late Permian is associated with the formation of a rifting basin. The second event which is correlated with the breakup and separation of Australia plate from India has occurred during the late Jurassic to early Cretaceous (Quaife et al. 1994; 
Marshall et al. 1989; Mory and Iasky, 1996). Whicher Range field is located 200 $\mathrm{km}$ south of Perth and $22 \mathrm{~km}$ south of the city of Busselton in Western Australia. This field is a large faulted anticline with the northeast trend in the Bunbury Trough (Fig. 1B), formed as a result of intense strike-slip movements during continental breakup (Crostella and Backhouse, 2000; Owad-Jones and Ellis, 2000; Sharifzadeh, 2008). Sandstone beds of the Willespie Formation from Sue Group with the late Permian in age constitute the reservoir zone of the field (Fig. 2). These beds with feldspathic sandstone, siltstone, shaleand coal lithology have been deposited as fining upward intervals within a river system. Coal and carbonaceous shales within the interval are considered as hydrocarbon sources, as it said the reservoir sandstones have a self-sourcing rock (Tobin et al., 2010). Shales, carbonaceous siltstones and coals have acted as intraformational cap rocks and permeability barriers for the reservoir sandstones of the field.

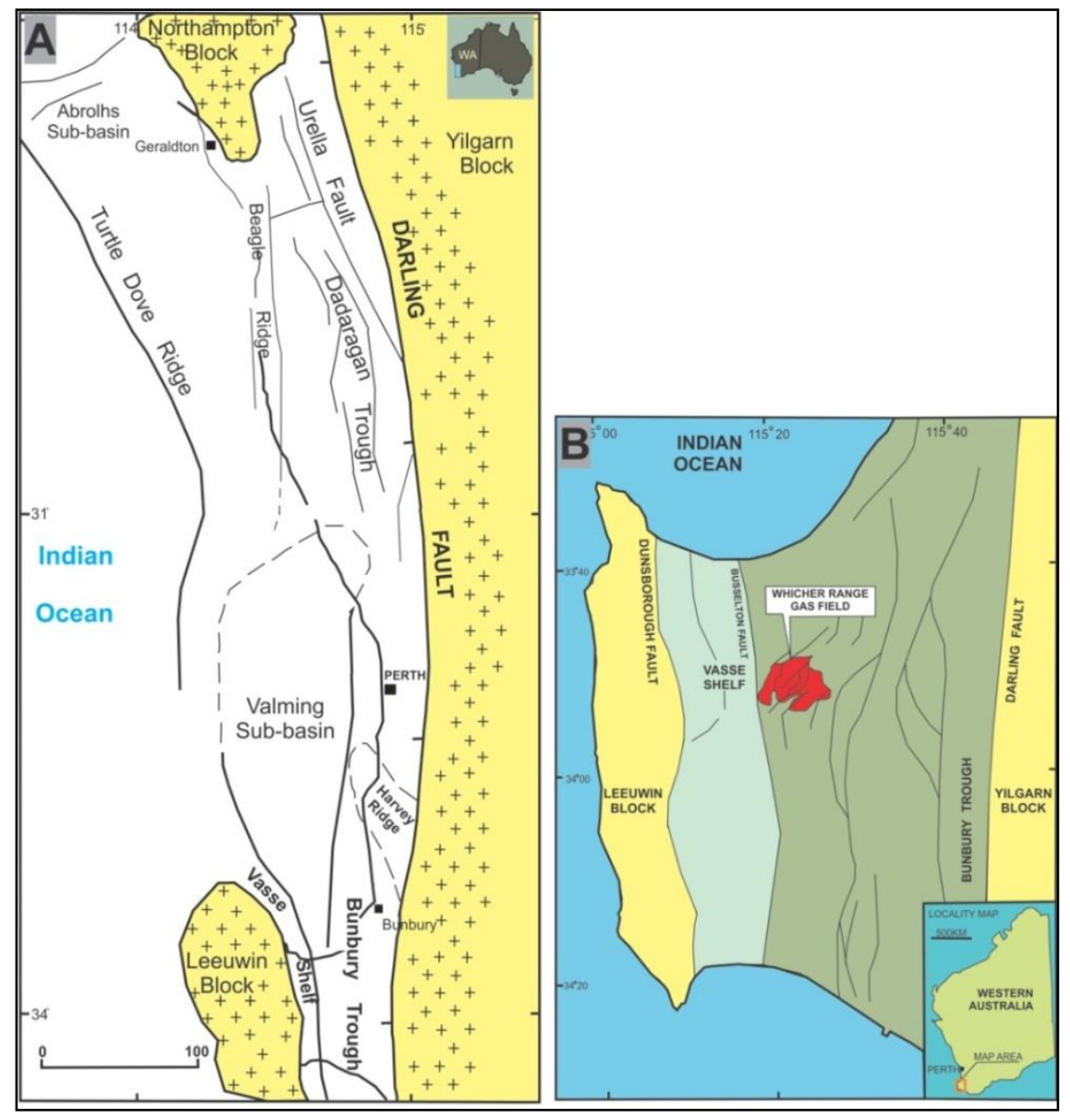

Fig. 1: A) General map of the Perth Basin in Western Australia (modified after Hall and Kneale, 1992). B) Location of the Whicher Range gas field in the Perth Basin (Sharifzadeh, 2008). 


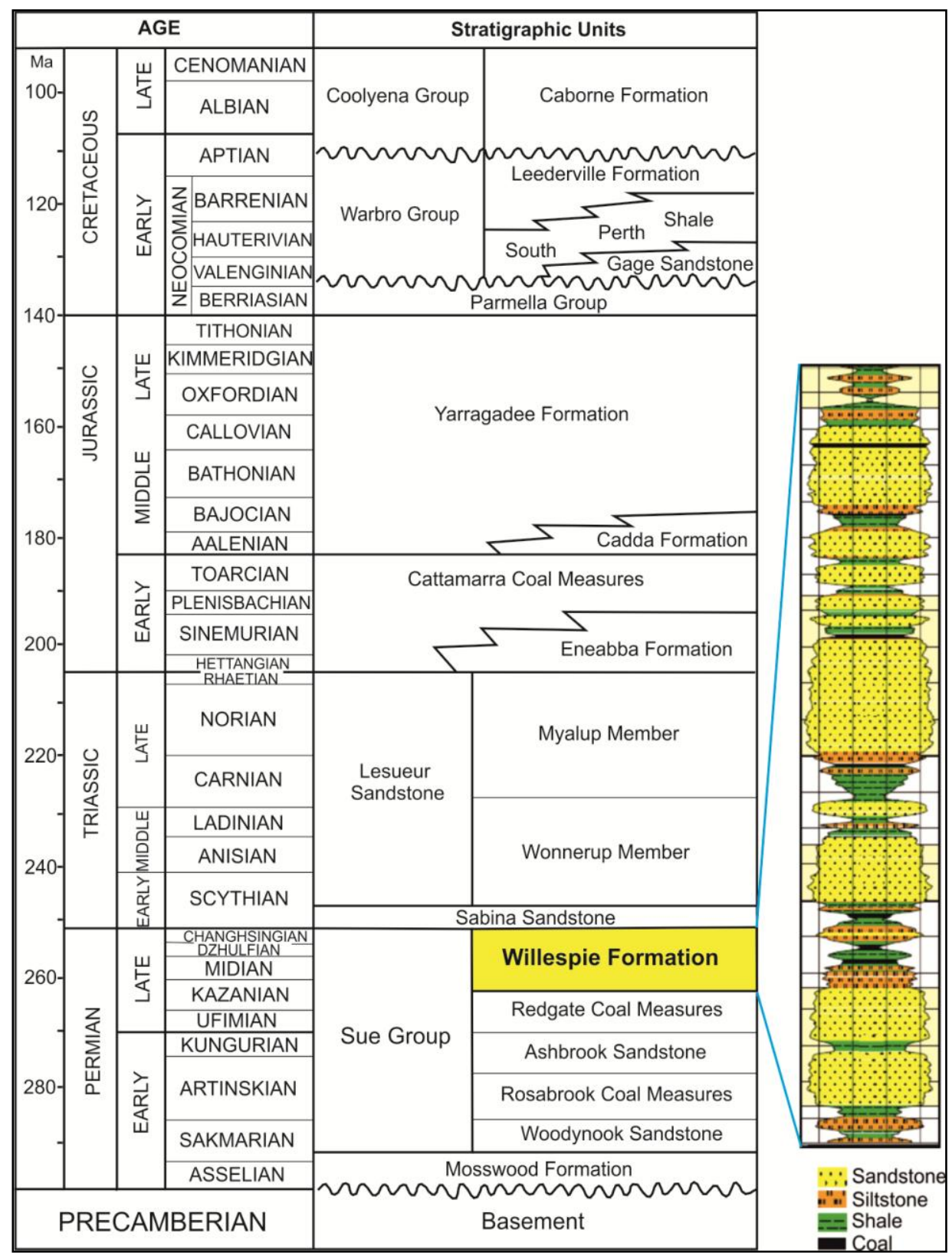

Fig. 2: Stratigraphy interval of the southern Perth Basin (Playford et al., 1976). The late Permian Willespie Formation, as reservoir rock of the Whicher Range field, with lithology composed of sandstone, siltstone, shaleand coal is highlighted in the stratigraphic column. 


\section{Data and Methodology}

In this study, with the target of modeling and investigation of facies and reservoir characteristics of the Willespie Formation sandstones in the Whicher Range field, core and well log data from five drilled wells in the field (WR1, WR2, WR3, WR4 and WR5) were used. Reservoir facies based on the results from the previous study (i.e., Kadkhodaie et al., 2013) are classified into three main facies including clean sandstones, shaly sandstones, shale and coal. For reservoir modeling, one interpreted UGC map from the top of the Willespie Formation in association with petrophysical logs (GR, DT, RHOBand NPHI) of five drilled wells were employed to build the framework of the model. Finally, the resultant facies and porosity models were extracted by geostatistical methods based on which the variation and distribution of these characteristics in the field are discussed.

\section{Facies and sedimentary environment of reservoir sandstones}

The Willespie Formation has a sedimentary interval consisting of fine to coarsegrained and gravelly feldspathic sandstones intercalated with shale, siltstone and coal. Quartz (mostly monocrystalline and minor polycrystalline), potassium feldspars and plagioclase are the main constituents of the sandstones, and rock fragments, micas (biotite and muscovite) and heavy minerals (garnet, zircon, tourmaline, epidote, magnetiteand goethite) have low frequency. Rock fragments are volcanic, metamorphic with afew chert and sedimentary types. Sandstones are clay-rich with weak sorting and subangular to subrounded grains. The sandstones are texturally and mineralogically immature to submature, and according to Folk et al (1970), they are classified as feldspathic to subfeldspathic arenite (Fig. 3). Textural, diagenetic and petrophysical characteristics of the Willespie sandstones have been summarized in Table1. The sandstones based on core description (lithology and sedimentary features), vertical sedimentary sequence and regional geology have been deposited in a meandering river system with low to medium sinuosity. Reservoir sandstones in this system are related to the channel, crevasse splay, levee, floodplain and paludal/lacustrine deposits. Sandstone facies within the channels show a fining upward sequence in which coarse and gravelly sandstones with an erosional surface have been deposited as bed load at the base of the channel and fine-grained facies with decreasing the energy started to deposit at top of the sequence. Low energy silty and shaly facies in association with coal 
constitute the floodplain and paludal deposits. Compaction mainly as mechanical and at the first stages of diagenesis and cementation by quartz, calcite and clay minerals at the next stages are the main diagenetic overprintsaffecting the pore system properties of the sandstones. Finally, a compacted and cemented fabric of reservoir facies has been developed, as they are considered tight. In comparison, although dissolution has acted as a diagenetic agent for improvement of reservoir quality, it is not widespread and the dissolution vugs are mostly isolated and noneffective. Figure 4 shows the integrated effect of different diagenetic processes and their impact on the tightness nature of the reservoir sandstones.

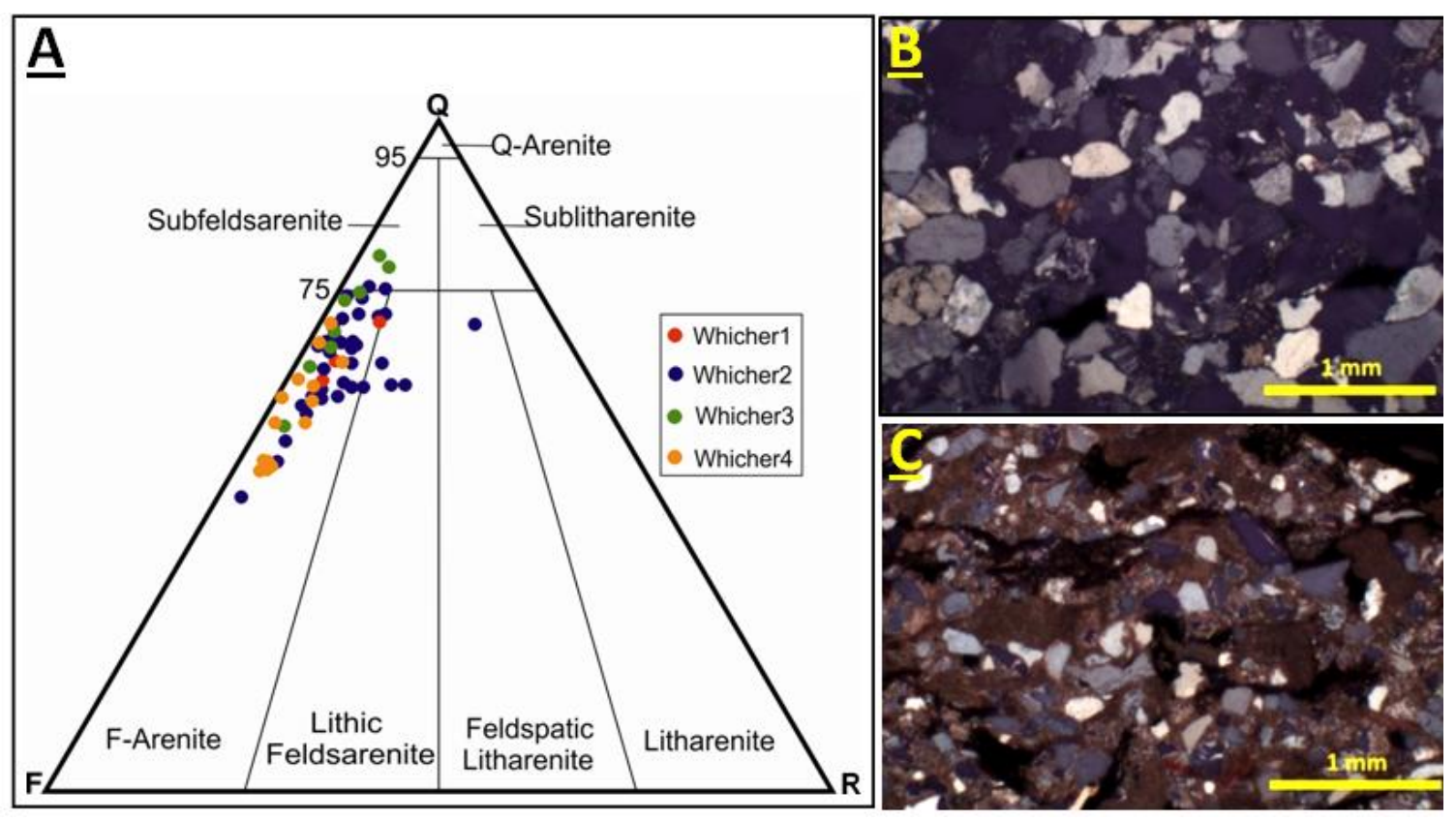

Fig. 3: A) QFR plot of the Whicher Range sandstones showing the majority are feldspathic with some sub-feldspathic arenite. Q: monocrystalline and polycrystalline quartz; F: total feldspar; R: total lithic fragments (after Folk et al., 1970). B) Medium-grained sandstone showing moderately well sorted, subangular to subrounded grains of quartz and feldspar. C) Fine-grained sandstone showing moderately sorted, angular to subrounded grains. Compacted, laminated fabric defined by carbonaceous material and detrital biotite flakes. 
Table1. A summary of textural and sedimentary characteristics, diagenetic features and petrophysical properties of the Willespie Formation in the Whicher Range field.

\begin{tabular}{|c|c|}
\hline $\begin{array}{c}\text { Sedimentary and } \\
\text { diagenetic features }\end{array}$ & Description \\
\hline Lithology & Feldspathic sandstone, siltstone, shale, coaly shale, coal \\
\hline Grain size & Fine to coarse-grained and in some cases gravelly sandstone \\
\hline Sorting & Weak to moderate (in fine-grainedsandstones is well) \\
\hline Roundness & Mostly subrounded to subangular \\
\hline Sedimentary structures & $\begin{array}{l}\text { Cross-bedding/lamination, fining upward sequence, bioturbation, } \\
\text { erosional surface, soft-sedimentary structures }\end{array}$ \\
\hline $\begin{array}{c}\text { Textural and } \\
\text { mineralogical maturity }\end{array}$ & Immature to submature \\
\hline $\begin{array}{l}\text { Sedimentary } \\
\text { environment }\end{array}$ & Meandering river with low to medium sinuosity, paludal \\
\hline Diagenetic features & Compaction (mostly physical), cementation, dissolution, replacement \\
\hline Cement type & Authigenic clays, calcite, silica \\
\hline Pore type & $\begin{array}{l}\text { Isolated dissolution pores, microporosity in clay minerals, minor } \\
\text { primary intergranular pores }\end{array}$ \\
\hline Porosity $(\%)$ & $5-16 \%$ \\
\hline Permeability (mD) & $<0.1$ to $>1 \mathrm{mD}$ \\
\hline
\end{tabular}

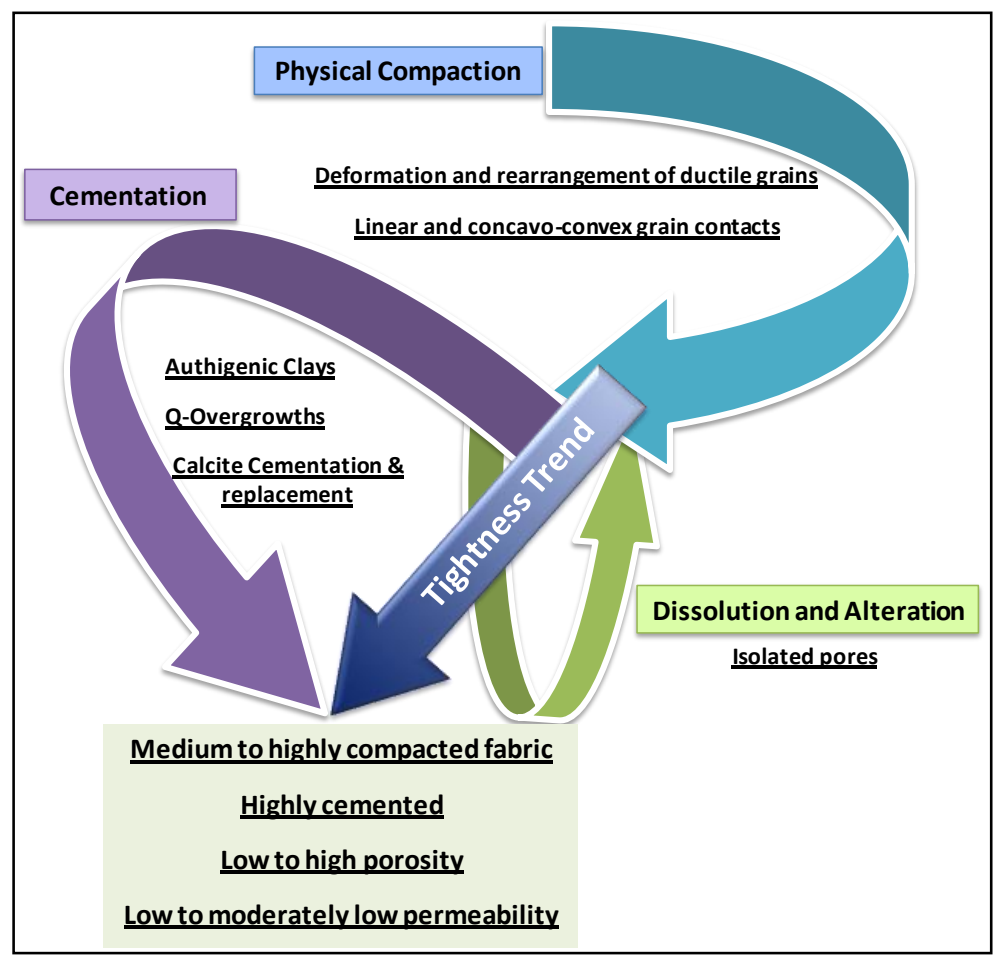

Fig. 4: The integration of the effects of compaction, cementation and dissolution on tightness nature of reservoir sandstones in the Whicher Range field. 


\section{Geocellular modeling}

In this stage, after gaining an understanding of depositional facies and environments and diagenetic features of the reservoir sandstones, work for building a 3D model showing the distribution of facies and petrophysical characteristics in the field was started. Accordingly, all relevant data derived from wells including core, well log, wellhead, well top in association with UGC map and fault data were loaded into the geological model database. Afterwards, reservoir modeling, according to the workflow shown in Figure 5, was accomplished. The stages are briefly described as follows.

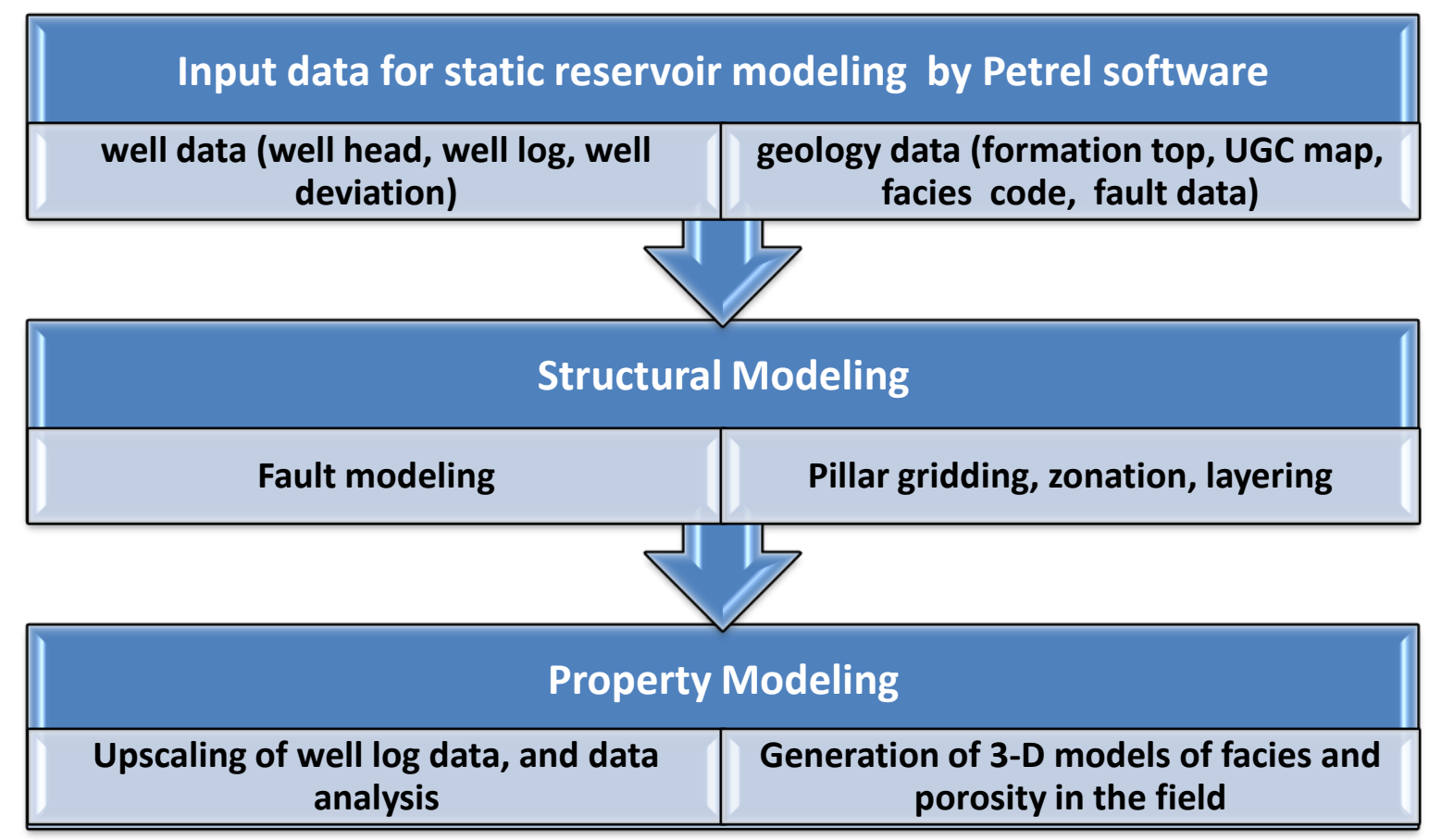

Fig. 5: Workflow for geocellular modeling of the Willespie Formation in the Whicher Range gas field. 


\subsection{Structural Modeling}

Anticline structure of the Whicher Range field, as mentioned above, has been affected by tectonic movements and the resultant faulting. Such faults have an important role on reservoir compartmentalization and they are predominantly NNE-SSW oriented with an average trend of $010^{\circ} \mathrm{N}$. This trend aligns well with the structural trend of the Bunbury Through (Ciftci, 2012). Data for these faults were loaded into the geological model database to constitute the fault surfaces within the 3D model (Fig. 6). Afterwads, the reservoir volume was gridded by cells with certain dimensions.

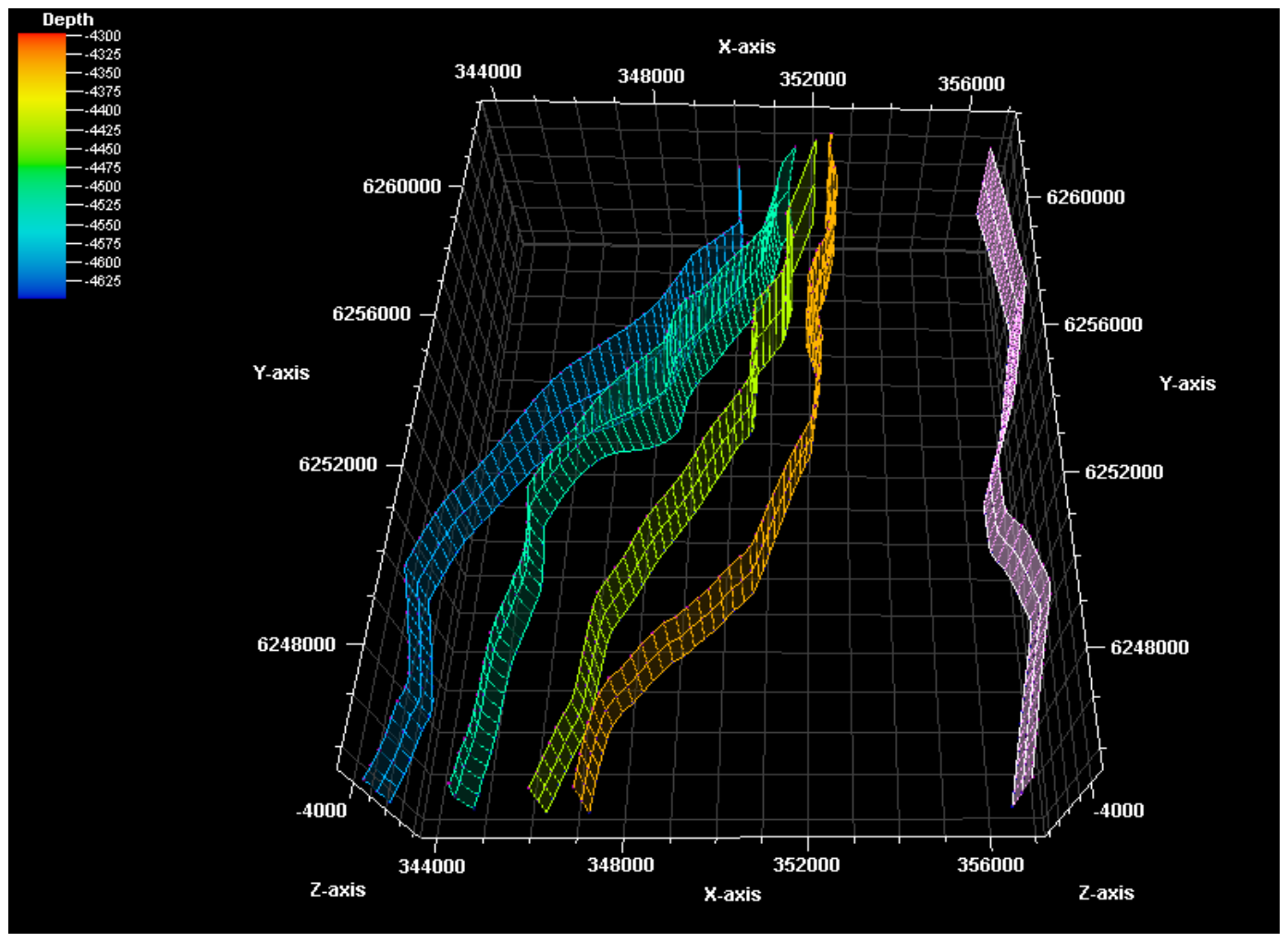

Fig.6: The position of faults with NNE-SSW trend used in reservoir modeling of the Whicher Range field.

The Willespie Formation in the Whicher Range field due to the alternation and overlapping of various units of sandstone, siltstone, shaleand coal shows a high lateral and vertical heterogeneity in lithology. Therefore, the reservoir interval based on the main sandstone packages is classified into numerous reservoir 
intervals, named as Latin letters (A, B, C..., W), in a descending order. Sandy packages which are correlatable between the wells, in fact, are identified based on DST and production flow test information provided by Pennzoil Far East Company (1998), and considered as reservoir units throughout the well interval. Also, nonreservoir shaly and silty intervals between them were named as sub-letters (i.e., A2, B2, C2 ...) in this study (Fig. 7). In geocellular modeling of the Whicher Range sandstones, the interpreted underground contour map (UGC) for the top of the Willespie Formation was used as a base surface (Fig.8). Afterwards, based on such a map, the surfaces for the different zones within the reservoir were determined. The reservoir zones were more subdivided into the layers with a specific thickness $(1 \mathrm{~m})$.

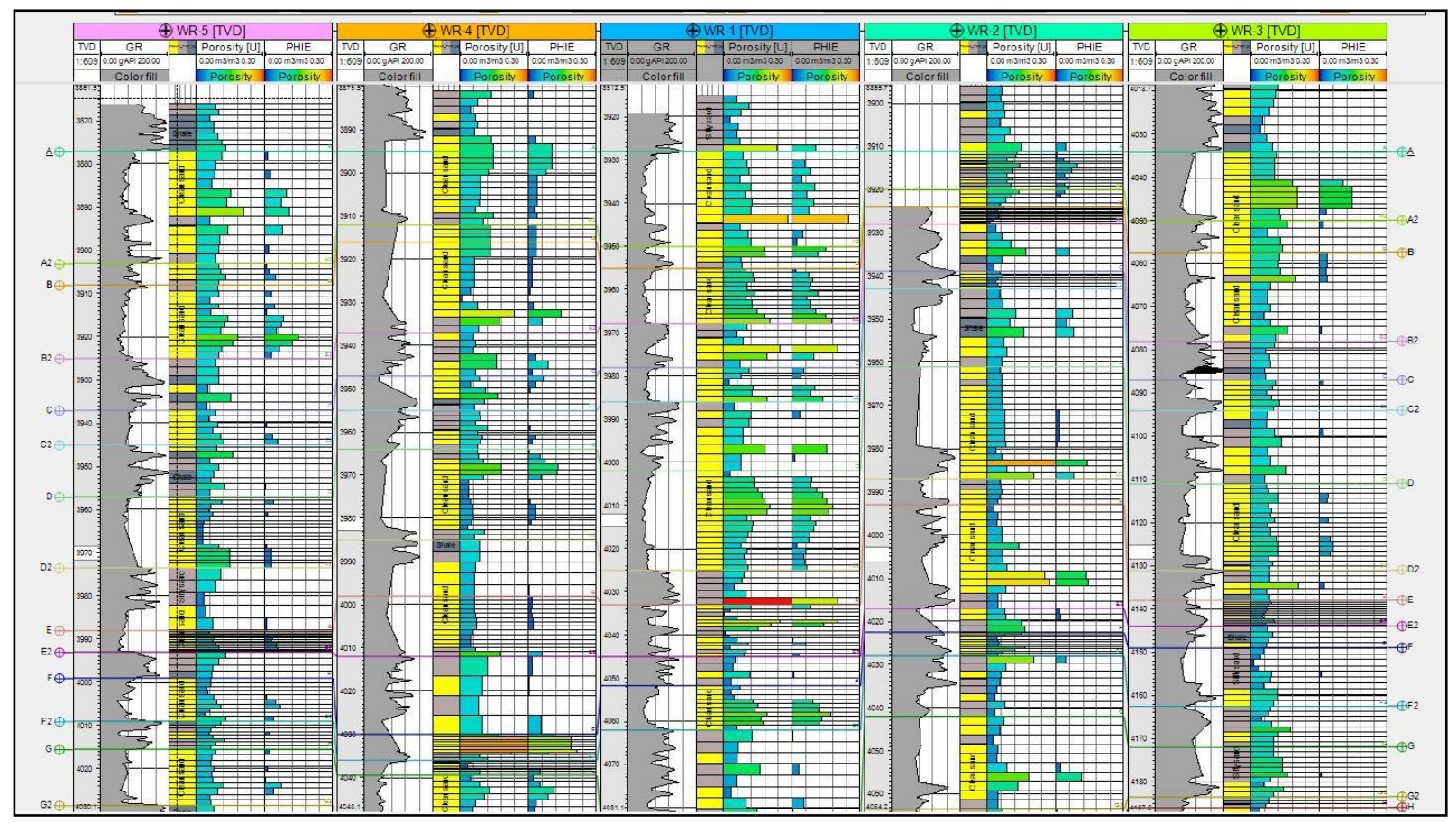

Fig. 7: Subdivision of the Willespie reservoir into various intervals (named as Latin letters) based on the main sandstone units which are correlatable between the wells in the field. 


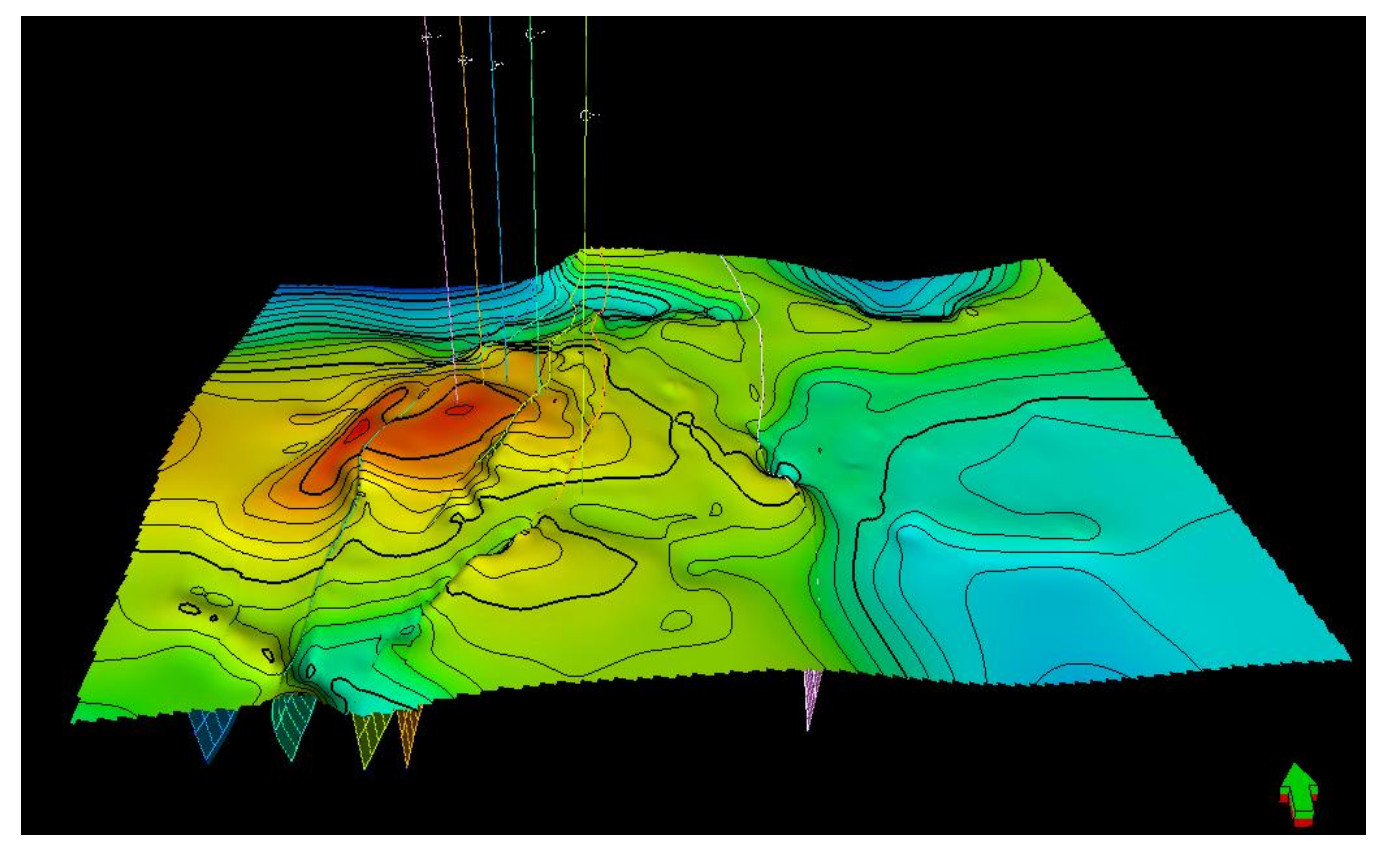

Fig. 8: UGC map for the top of the Willespie Formation in the Whicher Range field.

\subsection{Property Modeling}

After structural modeling and establishing the initial reservoir skeleton, facies and petrophysical characteristics of the reservoir sandstones based on the available data from five wells were modeled to investigate their distribution in the field. Variations in reservoir characteristics between the studied wells and throughout the field can be modeled using statistical methods. Three main steps for property modeling are described in below.

\subsubsection{Scale-up}

Propagating the reservoir properties within the grid cells is done by which each cell has a certain value for a specific parameter. But the grid cells often are much larger than the sample density for that parameter, and the parameter values within the cells must be scaled up before they can be entered into the grid. 


\subsubsection{Data analysis}

Data analysis process, as an important step in reservoir modeling, is used in controlling of data quality, investigation of their trend, and preparing the input data for facies and petrophysical modeling. In this study, variation trend of data in reservoir sandstones between the wells was investigated by variogram in three directions ( $\mathrm{x}$, yand $\mathrm{z}$ ). The main direction used in modeling was determined by variogram map derived from acoustic impedance (Fig. 9). In a variogram map, the direction of contour lines with the least variation or variance (east/northeast-west/south-west in this study) shows the most continuity of data in that direction which can be considered as the main direction of the variogram.

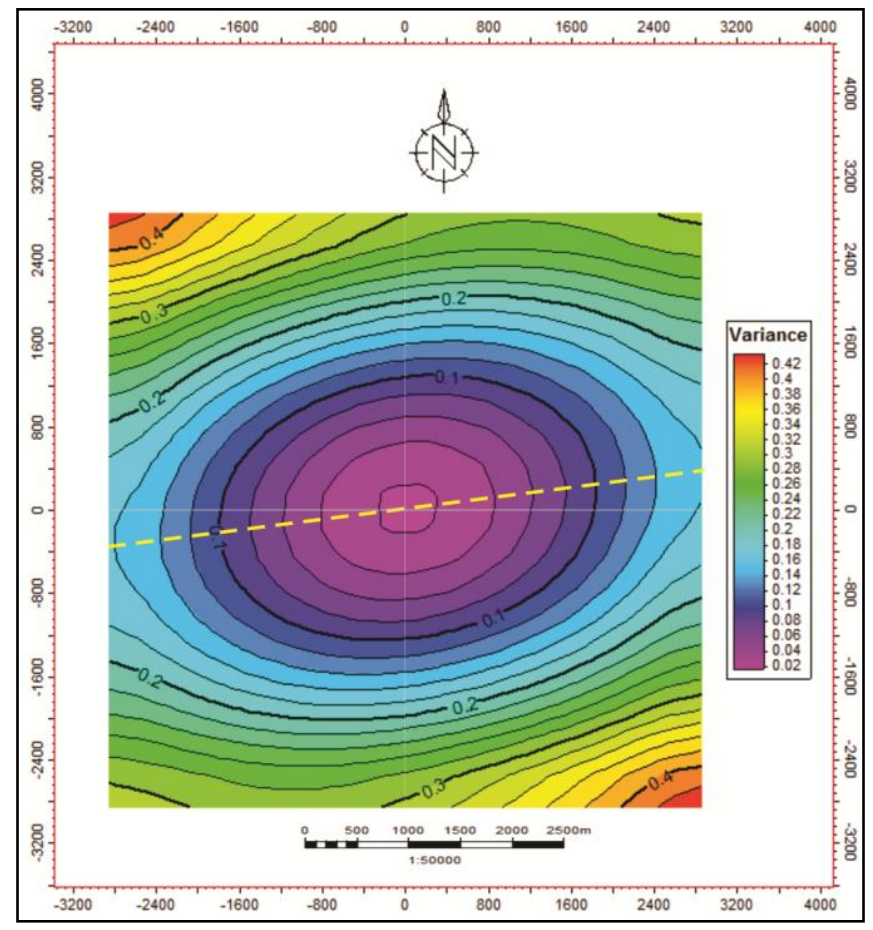

Fig. 9: Variogram map derived from acoustic impedance which is used to determine the main direction of variogram for modeling of reservoir sandstones in the studied field. 
5.3. Modeling based on a suitable algorithm

Two types of algorithms used in modeling are deterministic and stochastic. Deterministic methods such as Kriging and co-Kriging only produce one model and in areas with no data are unreliable. In contrast, stochastic algorithms such as Sequential Gaussian Simulation and Co-simulation produce more models in consecutive runs.

\subsubsection{Facies modeling}

Spatial and geometrical distribution of facies is considered as an important agent of heterogeneity in clastic reservoirs (Yao and Chopra, 2000). Among different methods used in modeling of reservoir facies, Object-based and Pixel-based algorithms are two main methods. The most common Pixel-based algorithm is Sequential Indicator Simulation. This method is based on the variograms that show the size and spatial distribution of facies patterns. Three groups of depositional facies in the Whicher Range field are clean sandstones $(\mathrm{GR}<100)$ as the main reservoir units, fine-grained and silty sandstones $(100<\mathrm{GR}<150)$ and shaly units (GR>150). A specific digital code was assigned to each facies group for loading into themodel database. Data analysis was accomplished by their interpolation with a suitable variogram model (spherical) in three spatial directions. Afterwards, facies model using well data information and based on the Sequential Indicator Simulation was extracted (Fig.10). According to the facies model, clean sandstone facies which constitute the main reservoir units are interlayered with silty sandstones and shales, and they show a significant change in thickness and their lateral and vertical continuity throughout the reservoir interval. 


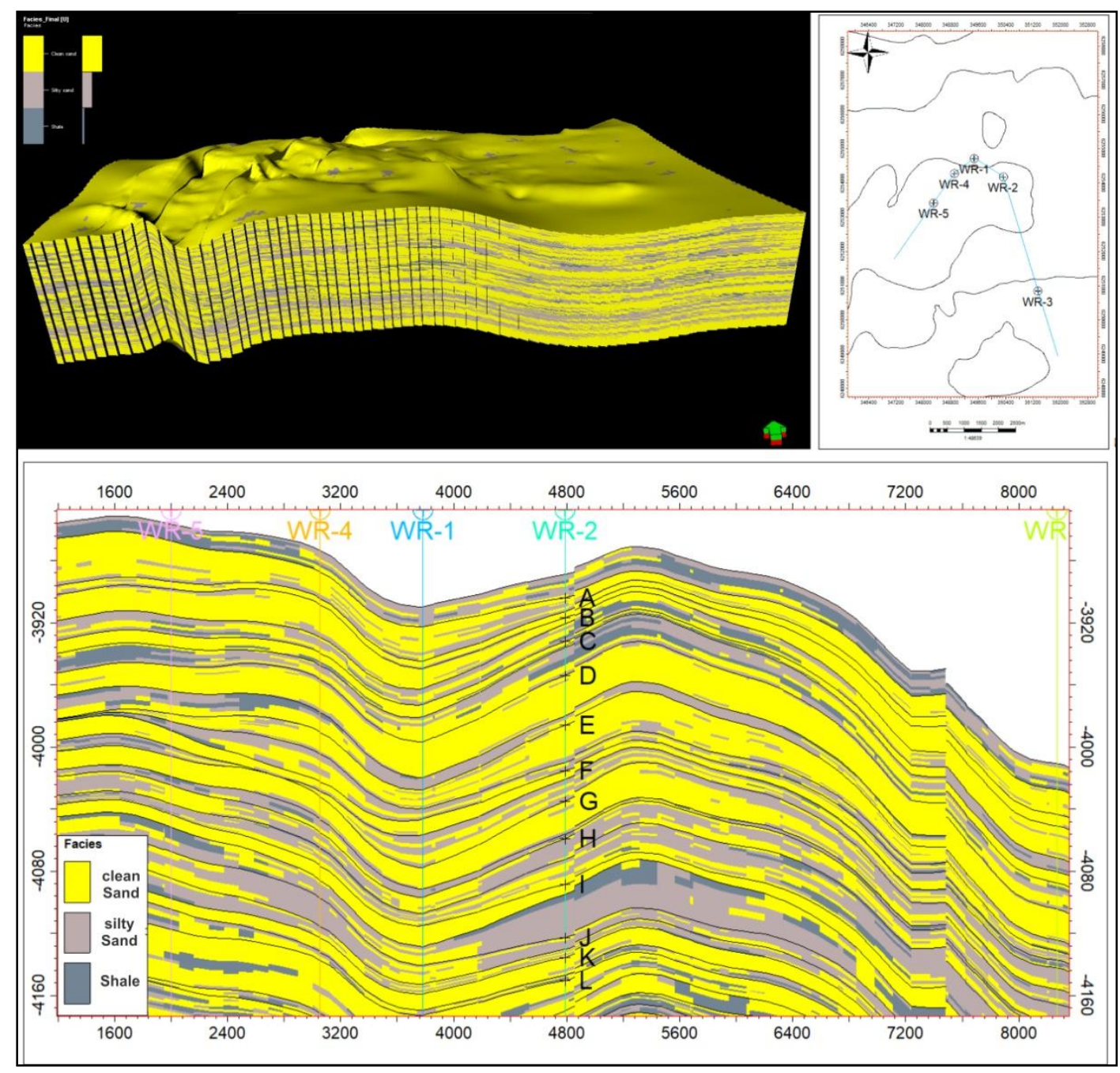

Fig. 10: 3D facies model and its cross-section along the wells of the Whicher Range field showing the distribution of reservoir facies (clean sand, silty sandand shale) in the field.

\subsubsection{Porosity modeling}

Porosity model of reservoir sandstones in the Whicher Range field was created using Sequential Gaussian Simulation algorithm. Due to the clear and inverse relationship between the acoustic impedance (AI) and porosity (Fig. 11), it was used as the key control for modeling of porosity attribute. Accordingly, the cokriging method was used to integrate the porosity and acoustic impedance data for reservoir modeling. In fact, co-kriging is a multivariate estimation method by which the spatial relationship between the primary and secondary variables is 
analyzed, and the secondary variable is utilized in estimation to compensate the deficiency of primary variable.

Porosity was considered as the total and effective and it was analyzed by spherical variogram in three spatial directions. The extracted 3D models of total and effective porosity were shown in Figure 12 and Figure 13, respectively. According to the constructed models, total porosity shows significant increase towards the top of the formation. Such a result indicates porous zones have been concentrated in the upper parts of the reservoir. This can also be seen in Figure 14, as the porosity shows an increasing trend from the lower zones of the reservoir to its upper zones. Although, effective porosity follows the same trend as total porosity, it has a sparse distribution within the reservoir interval. This is attributed to the effect of diagenetic processes (e.g., compaction, cementation and dissolution) on pore system properties, which is consistent with the tight nature of reservoir sandstones. It can be concluded that the initial sedimentary characteristics control the largescale variations in reservoir properties including total porosity, and also the distribution of reservoir zones in the field. In contrast, diagenesis has the main control on effective porosity and internal reservoir heterogeneity.

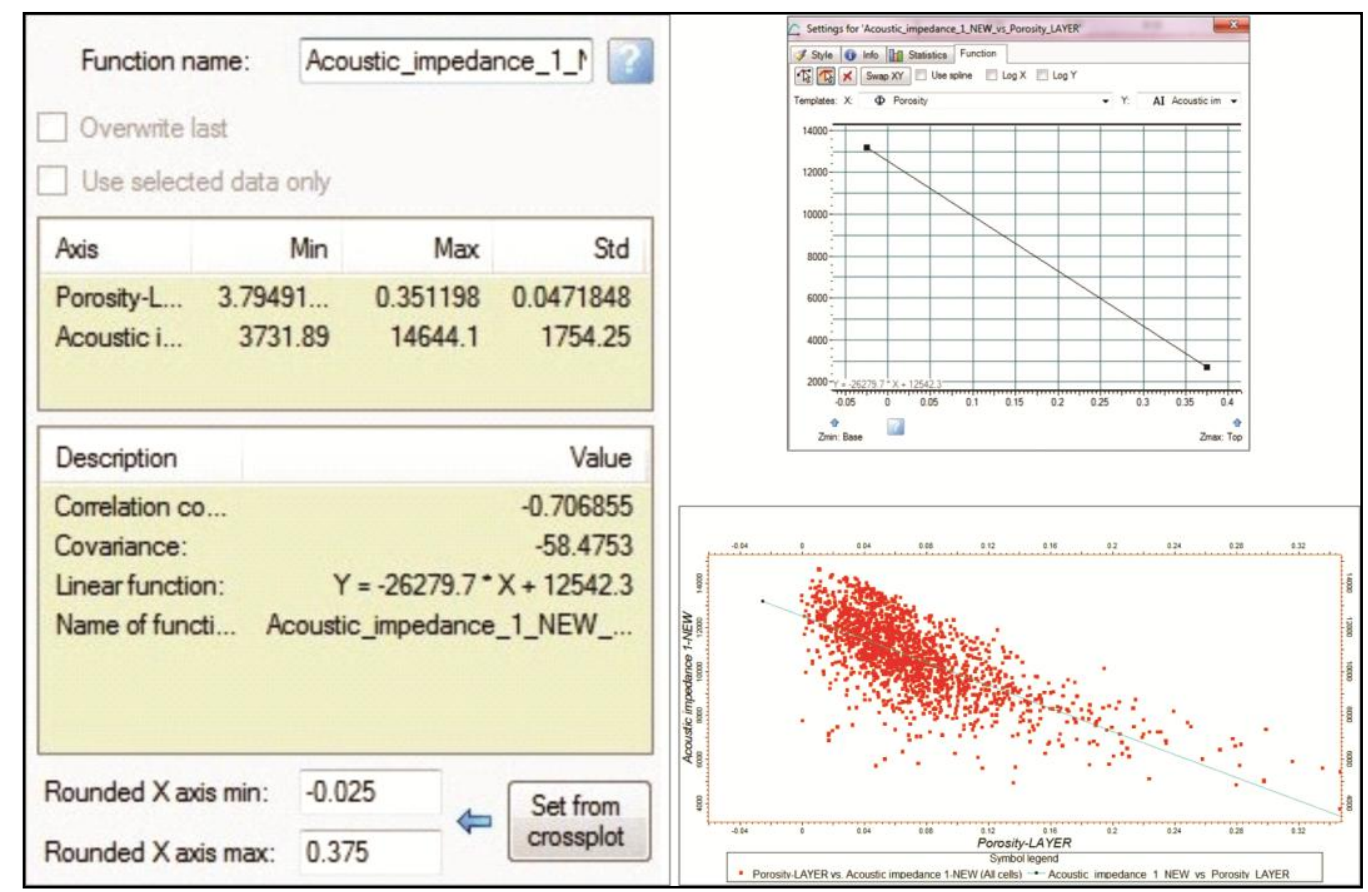

Fig. 11: Inverse relationship between acoustic impedance and porosity of reservoir sandstones in the Whicher Range field. 


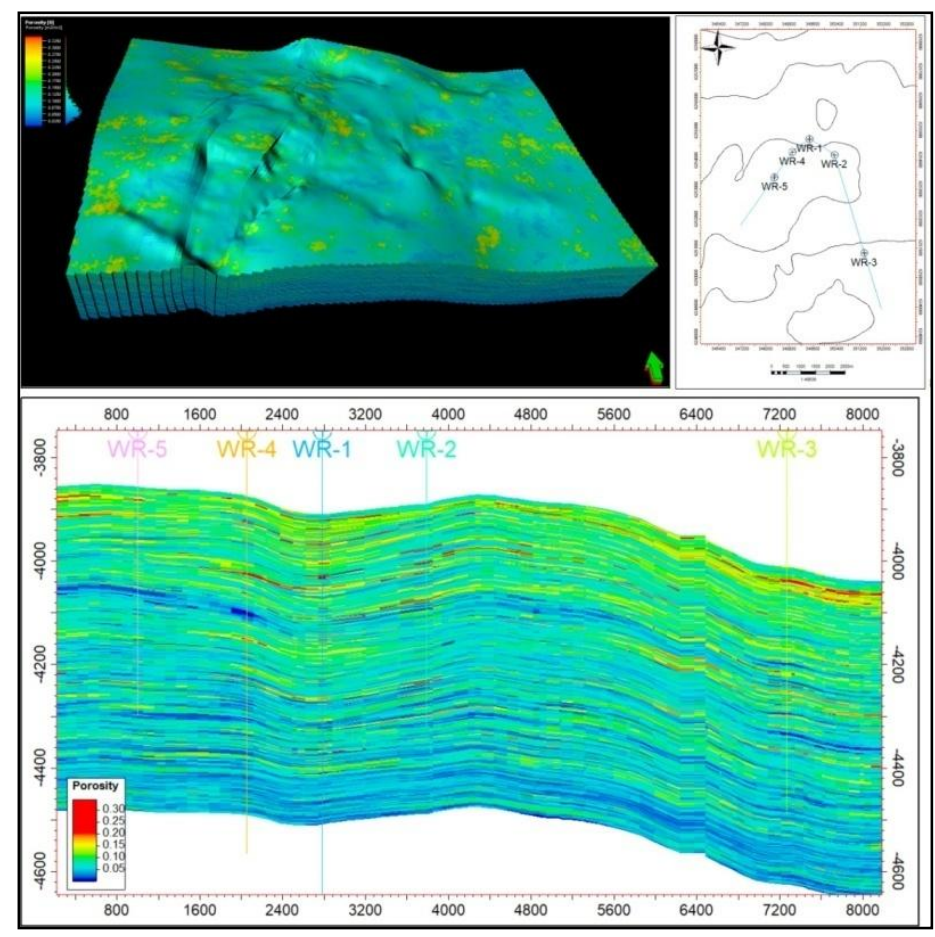

Fig. 12:3D model of porosity and its cross section showing the distribution of total porosity in the studied field.

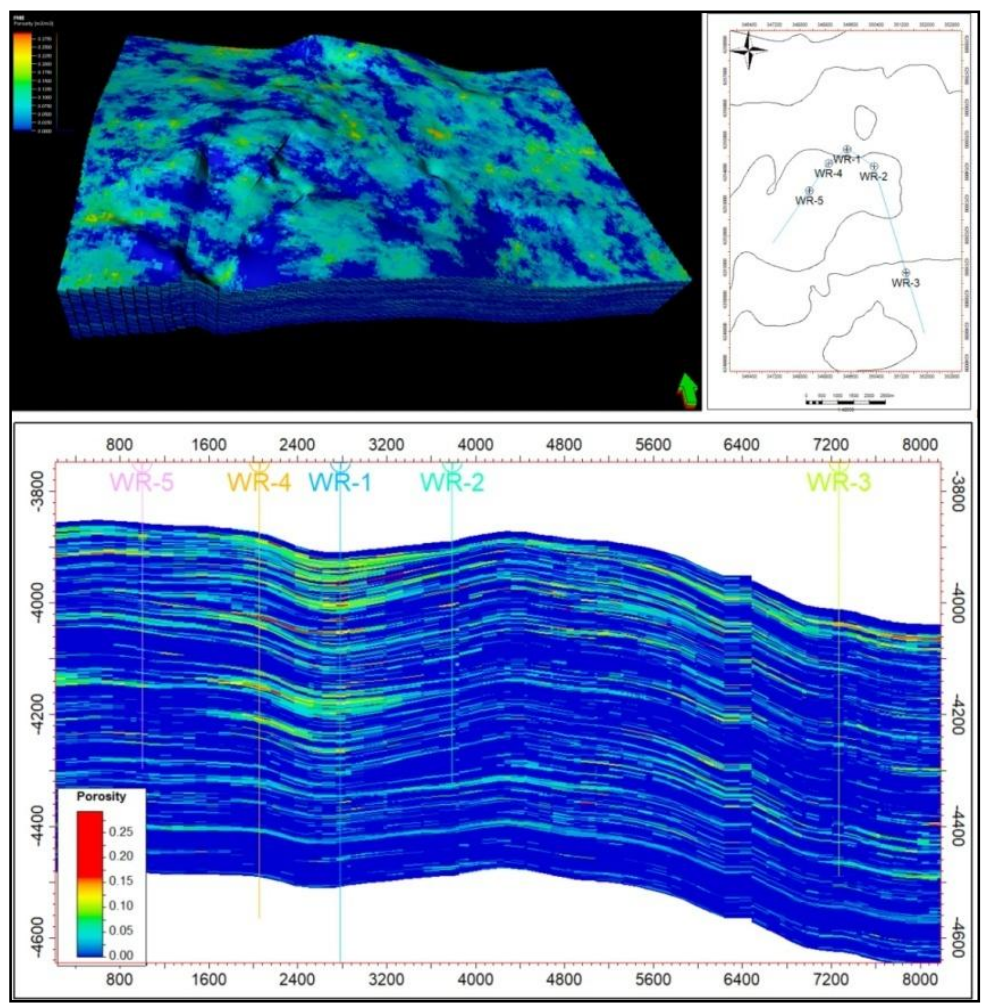

Fig. 13: 3D model of porosity and its cross section showing the distribution of effective porosity in the studied field. 


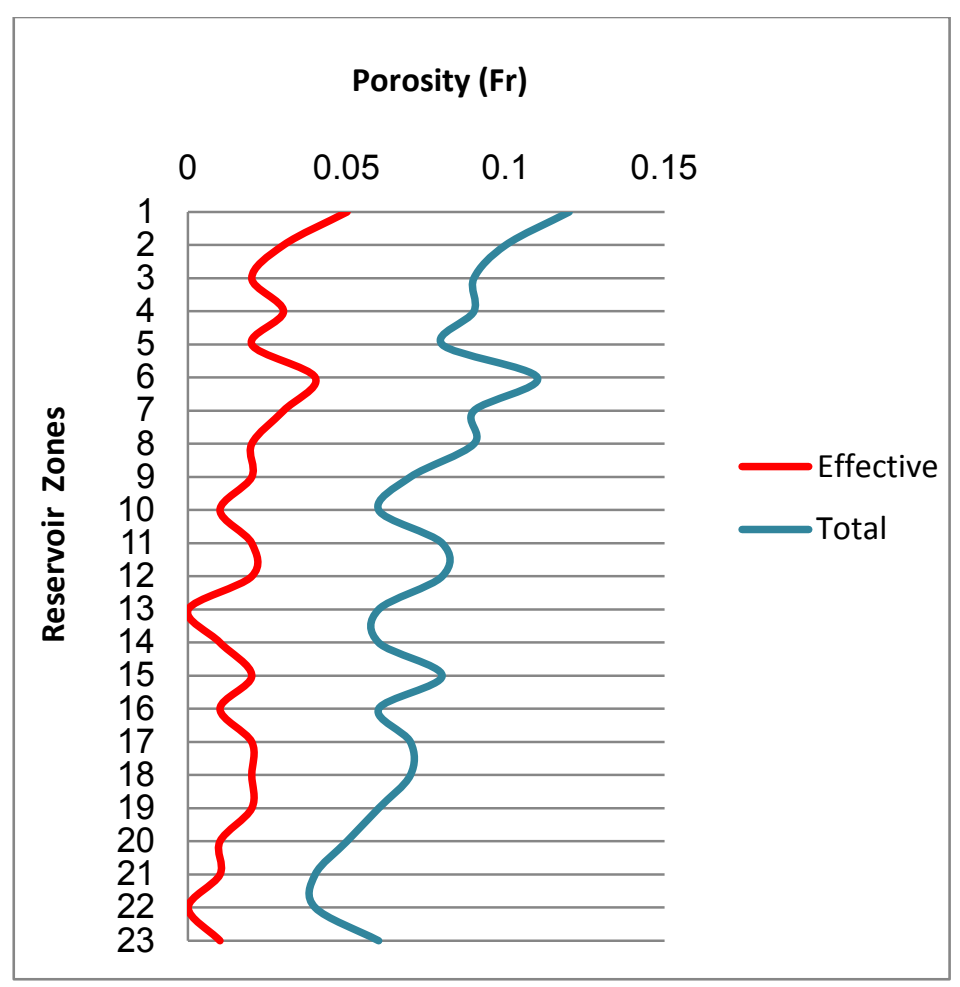

Fig. 14: Increasing trend of total and effective porosity from lower reservoir zones towards the upper zones of the Willespie Formation.

\section{Results and discussion}

The study results from regional geology, sedimentology (facies and diagenesis), and reservoir modeling of tight sandstone facies of the Willespie Formation demonstrate the effects of depositional characteristics, diagenesis and tectonic history on reservoir heterogeneity, and distribution and development of different reservoir zones within the field. The effects of such agents are described in detail in below.

\subsection{Depositional characteristics}

Changes in depositional environments have been proved to be a control in reservoir properties (Weber, 1980). The results from facies and porosity modeling of the Whicher Range tight sandstones unravel the main control of depositional characteristics on reservoir heterogeneity and distribution of reservoir zones in the 
field. Such facies which have been developed in different parts of a river system show wide variations in sedimentary characteristics throughout the reservoir interval. In a comparison between the reservoir sandstone facies with their core porosity and permeability data, Orsini and Rezaee (2012) demonstrated that low reservoir quality is mostly related to floodplain (FP), crevasse splays (CS) and channel margins $(\mathrm{MCH})$ whereas better qualities are associated with channel $(\mathrm{CH})$ and crevasse channel facies (CSCH) (Fig. 15). Overall, intervals of lower reservoir quality seem to relate to the more argillaceous facies which is more likely to be controlled by the depositional environment.

According to the results from reservoir modeling in this study, most porous zones are coincident with coarse and high energy sandstone facies with high thickness and more continuity of fluvial channels that have been distributed as an individual or a set of stacked channels at the upper part of the formation (Figs. 10 and 12). In addition, investigation of the reservoir facies along the Whicher Range wells, based on the porosity models and also a 3D model of shale in the field (Fig. 16), indicates wells WR1 and WR4 have more porous and thicker zones than the other wells in their interval. This is consistent with the results from production tests and the results from previous studies (e.g., Kadkhodaie-Ilkhchi et al., 2013) mentioning high production and most promising sandstone zones in these wells. Also, thickness map of reservoir sandstones shows a decrease of the sand contribution towards the south-east parts of the field where WR2 and WR3 are situated (Fig. 17). Fence diagrams of facies and porosity models of the reservoir sandstones were shown in Figure 18.

Based on the integration of results from facies and porosity modeling, it can be concluded that despite the effect of diagenetic processes on pore system and tightness of the Whicher Range sandstones, distribution of reservoir zones in the field is mainly controlled by their initial facies characteristics and depositional environment. 


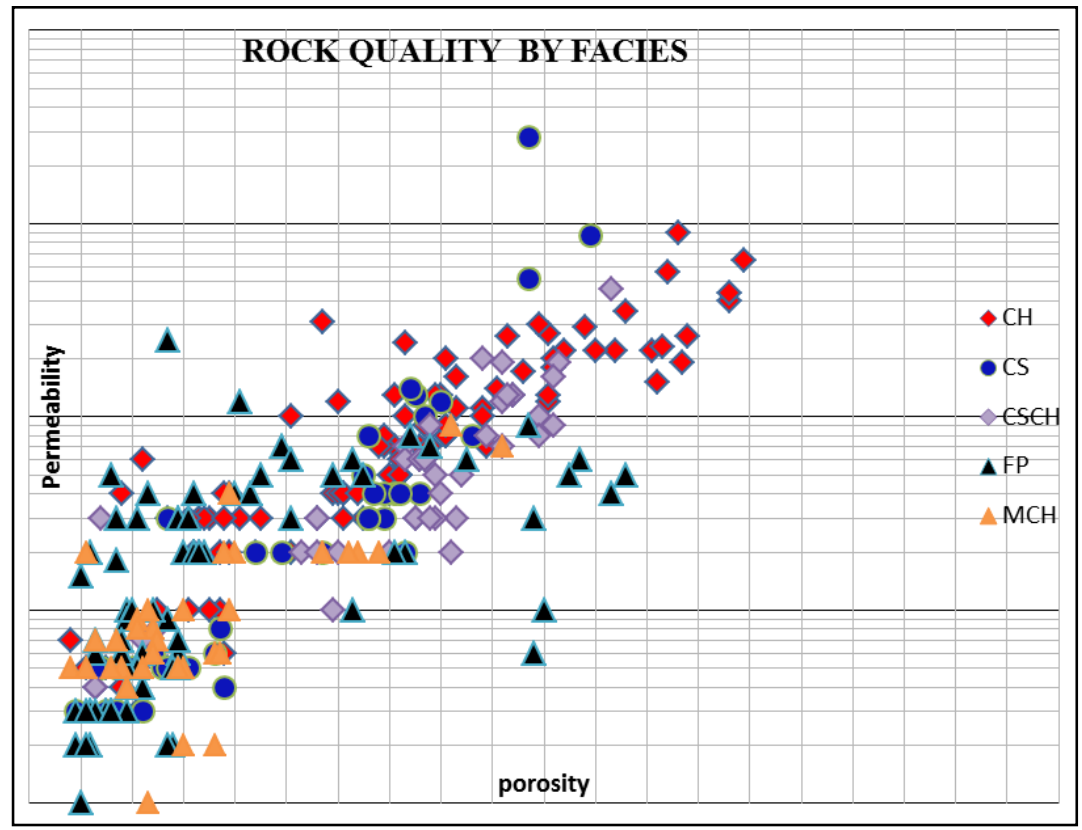

Fig. 15: Porosity and permeability plot for different facies in Whicher Range field (after Orsini and Rezaee 2012).

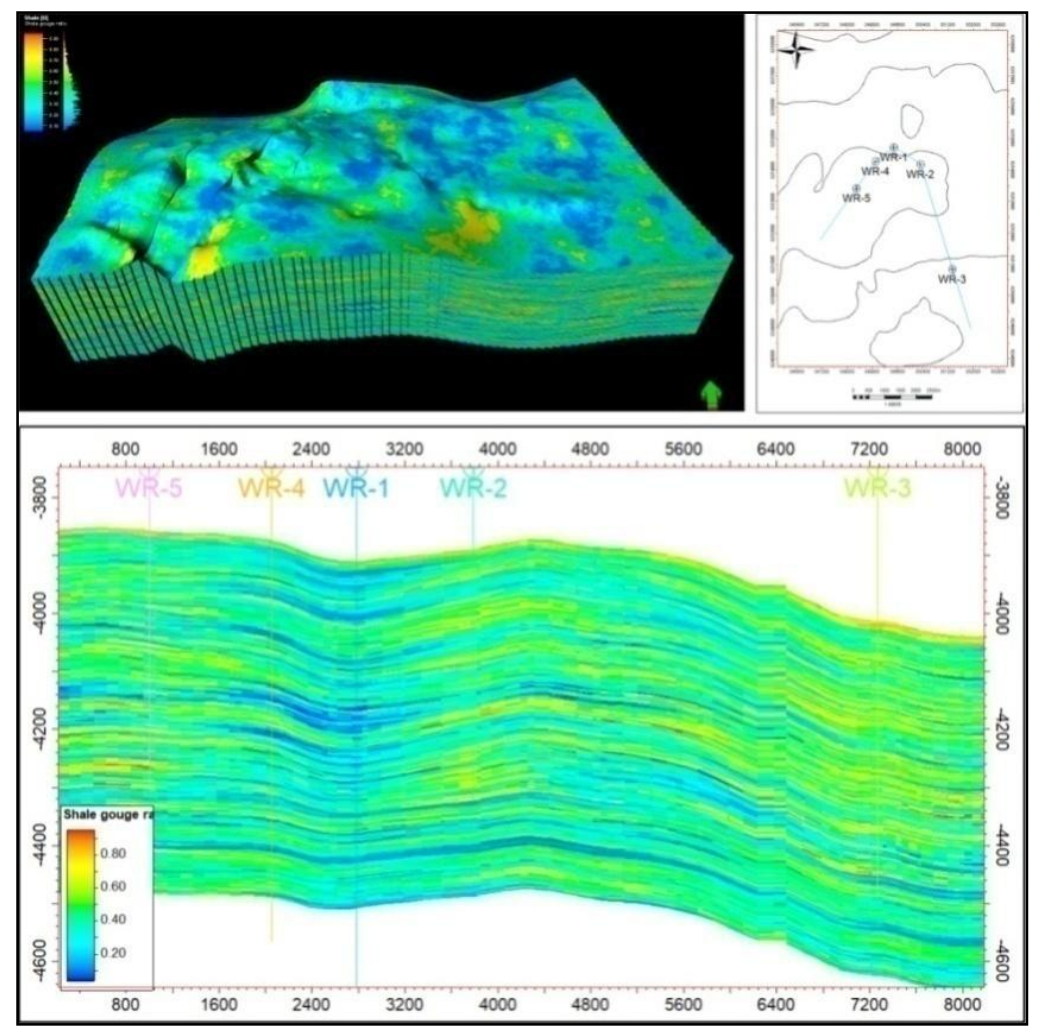

Fig. 16: Spatial model of sandstones and its cross section showing the distribution of shale in the studied field. 


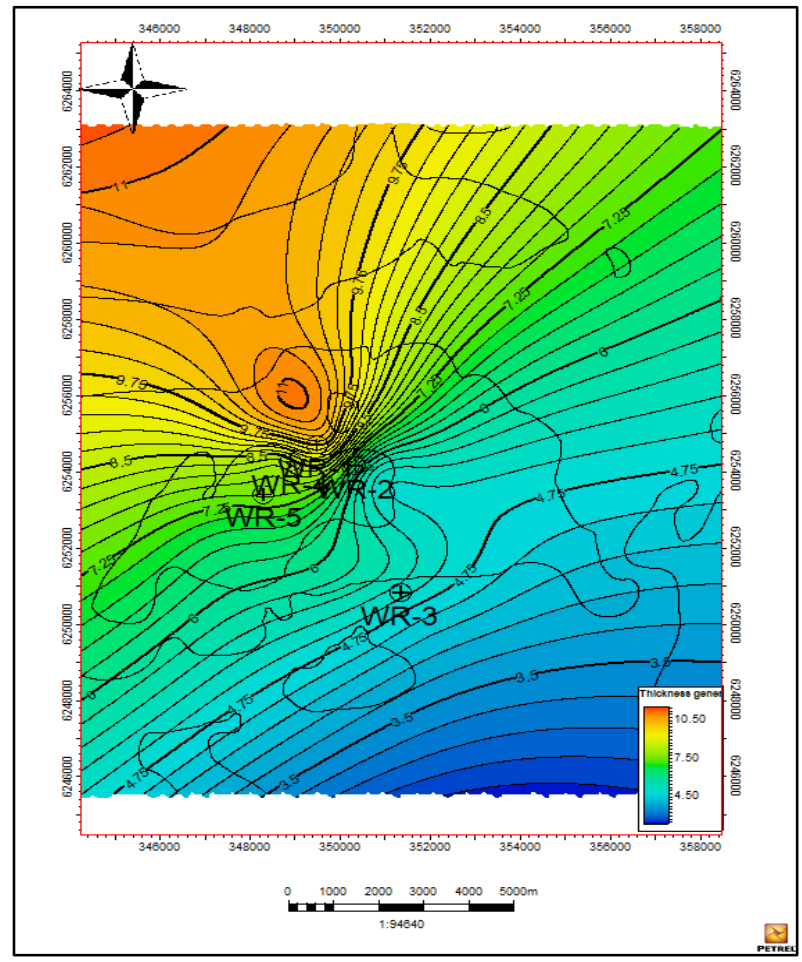

Fig. 17: Thickness map of sand in the Whicher Range Field.

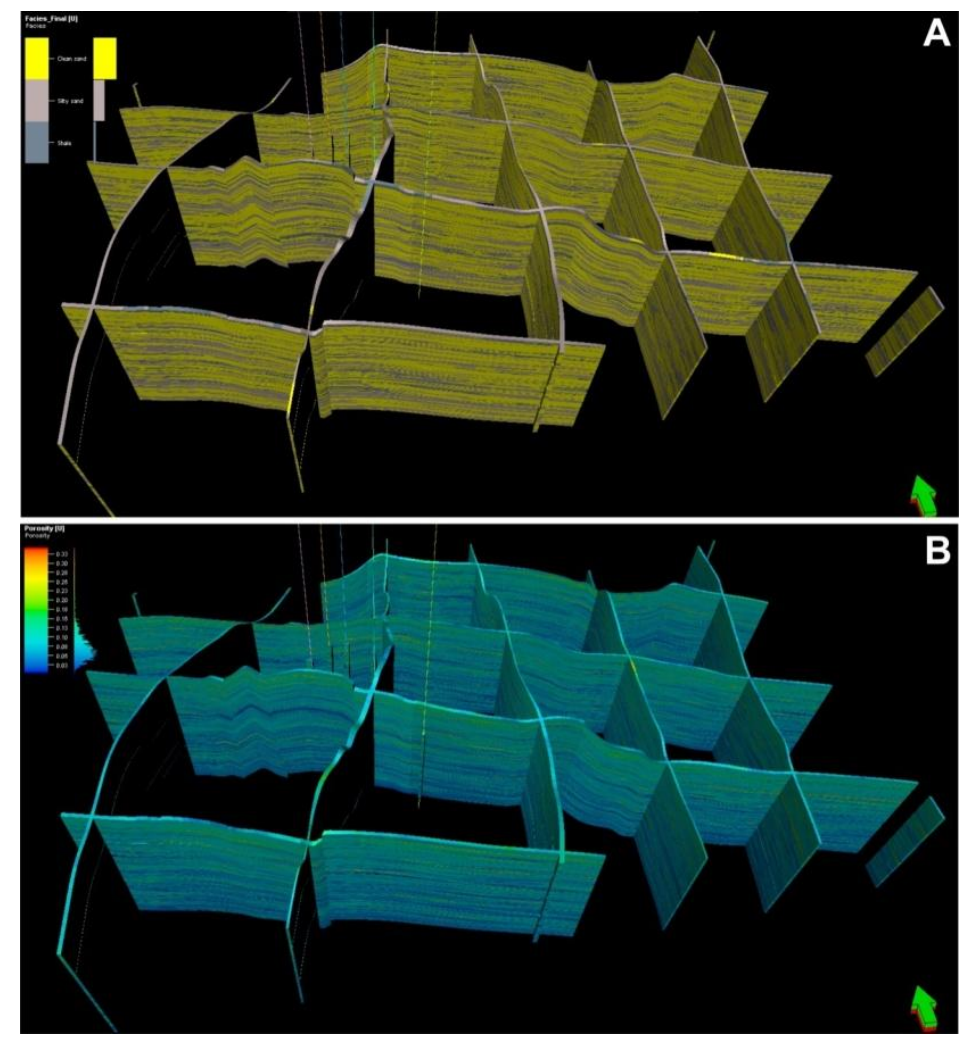

Fig. 18: Fence diagrams of extracted facies (A) and porosity (B) models in the studied field. 


\subsection{Mineralogy and diagenesis}

Diagenesis has the main control on pore system properties of reservoir sandstones in the field. In fact, tight sandstone facies of the Whicher Range field under the effect of compaction, cementation and dissolution are characterized by a compacted and cemented fabric with low to high porosity and especially low permeability (Fig. 4). In addition to initial sedimentary texture, one factor which also controls the effect of diagenesis on reservoir facies is the mineralogical composition of reservoir facies that is attributed to the presence of unstable and ductile minerals and components such as feldspars, micas and rock fragments. The components, in fact, have provided and accelerated the condition for acting of compaction, alteration and dissolution within the reservoir that has been resulted in modification of pore system properties and increasing of internal reservoir heterogeneity. Figure 19 (A and B) show how the compaction has differently acted on two sandstone facies of the reservoir. According to this figure, sandstone facies A due to the fine-grained texture and also the presence of ductile grains (mica) has been more compacted than medium to coarse-grained facies B. In Figure 19C, the effect of dissolution is observed as isolated vugs.

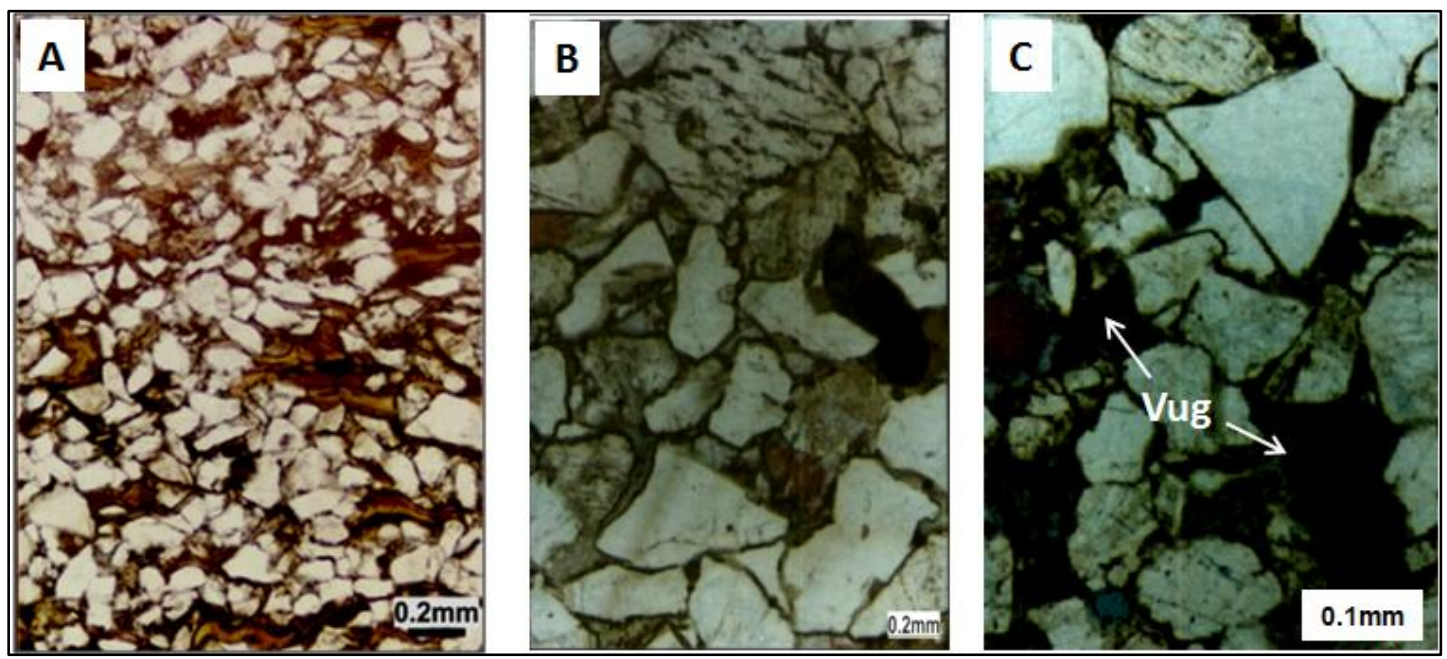

Fig. 19: Different effect of compaction on two sandstone facies of the Whicher Range field. A: fine-grained facies with ductile grains between quartz grains. B: medium to coarse-grained sandstone facies. C: The effect of dissolution that is observed as isolated vugs within the reservoir facies. 


\subsection{Tectonic history}

Faulted and anticlinal structure of the Whicher Range field, as mentioned above, is related to tectonic and evolution history of the Perth Basin. According to Lasky (1993) the seismic data indicates that the Permian sequence thickens eastwards towards the Darling Fault and suggests that the fault controlled sedimentation during that time. Therefore, pore system of deeply buried $(\sim 4 \mathrm{~km})$ sandstone facies of the Willespie Formation are initially affected by the basin subsidence along faults, as they are characterized by a compacted fabric. The effect of compaction especially in fine-grained and silty-shaly sandstone facies is more significant (Figs. $19 \mathrm{~A}$ and $\mathrm{B})$.

\section{Conclusion}

Investigation of tight gas sandstones of the Willespie Formation in Whicher Range field based on 3D facies and porosity modeling demonstrates that there is a close relationship between sedimentary characteristics and reservoir properties of these sandstones in the field. As a significant part of porous zones are related to clean and coarse sandstone facies deposited in channels of a fluvial system. In fact, depositional characteristics have a significant control on large-scale reservoir heterogeneity and distribution of reservoir zones in the field. In contrast, diagenetic processes such as compaction, cementation, and dissolution have been inserted their effect on internal reservoir heterogeneity related to pore system properties of reservoir sandstones.

\section{Acknowledgements}

The authors extend their appreciation to the Whicher Range Energy for providing necessary data to perform this study and to permit us to publish this paper. 


\section{References}

Al-Khalifah, M., Makkawi, M., 2002. The impact of data integration on geostatistical porosity modeling: a case study from the Berri field, Saudi Arabia. Journal of Petroleum Geology 25 (4), 485-498.

Ciftci, B., 2012. First order reservoir modeling of the Whicher Range Field tight gas sands. Whicher Range tight gas sands study, Western Australian Energy Research Alliance, Report $112,288-307$.

Crostella, A., Backhouse, J., 2000. Geology and petroleum exploration in the central and southern Perth Basin: Western Australia Geological Survey, Report 57, 85 pp.

Desbois, G., Urai, J.L., Kukla, P.A., Konstanty, J., Baerle, C., 2011. High-resolution 3D fabric and porosity model in a tight gas sandstone reservoir: A new approach to investigate microstructures from $\mathrm{mm}$ - to nm-scale combining argon beam cross-sectioning and SEM imaging. Journal of Petroleum Science and Engineering 78, 243-257.

Folk, R.L., Andrews, P.B., Lewis, D.W., 1970. Detrital sedimentary rock classification and nomenclature for use in New Zealand. New Zealand Journal of Geology and Geophysics 13, 937-968.

Hall, P. B., Kneale, R. L., 1992. Perth Basin rejuvenated. Australian Petroleum Exploration Association Journal 32 (1), 33-43.

Izadi, M., Ghalambor, A., 2012. A new approach in permeability and hydraulic flow unit determination, SPE Reservoir Evaluation \& Engineering 16, 3, 257-264.

Kadkhodaie-Ilkhchi, R., Rezaee R., Moussavi-Harami R., Kadkhodaie-Ilkhchi, A., 2013. Analysis of the reservoir electrofacies in the framework of hydraulic flow units in the Whicher Range Field, Perth Basin, Western Australia. Journal of Petroleum Science and Engineering 111, 106-120.

Iasky, R.P., Young, R. A., Middleton M.F., 1991. Structural Study of the Southern Perth Basin by Geophysical Methods, exploration Geophysics, V 22, p 199-206.

Marshall, J.F., Lee, C.S., Ramsay, D.C., Moore, A.M.G., 1989. Tectonic controls on sedimentation and maturation in the offshore north Perth Basin. Australian Society of Exploration Geophysicists Journal 29, 450-465. 
Mory, A. J., Iasky, R. P., 1996. Stratigraphy and structure of the onshore northern Perth basin, Western Australia: Western Australia Geological Survey, Report No. 46, 101 pp.

Owad-Jones, D., Ellis, G., 2000. Atlas of petroleum fields, onshore Perth Basin, Petroleum Division, DMEWA1, 122.

Pennezoil Far East Company, 1998. A review of the reservoir properties of the Sue Coal Measures in the Whicher Range Field area, South Perth Basin, Western Australia. 81 pp.

Playford, P.E., Cockbain, A.E., Low, G.H., 1976. Geology of the Perth Basin, Western Australia. Geological Survey of Western Australia Bulletin 124, 311 pp.

Quaife, P., Rosser, J., Pagnozzi, S., 1994. The structural architecture and stratigraphy of the offshore northern Perth Basin, Western Australia. In: Purcell, P.G, Purcell, R.R. (Eds.), The Sedimentary Basins of Western Australia. Proceedings of Petroleum Exploration Society of Australia Symposium. Petroleum Exploration Society of Australia, 811-822.

Qiulin, G., Jianzhong, Li., Ningsheng, C., Junwen, H., Hongbing, X., Xiaohui, G., 2011. Modeling of the tight sandstone gas accumulation for the Xujiahe Formation, HechuanTongnan Area, Sichuan Basin. Petroleum Exploration and Development 38(4), 409-417.

Orsini, C., Rezaee, R., 2012. Depositional Systems Sequence Stratigraphy Frameworks \& Geological Modelling of Fluvial Bodies. Geological Survey of Western Australia, Report 112, $405 p$.

Pennezoil Far East Company, 1998. A review of the reservoir properties of the Sue Coal Measures in the Whicher Range Field area, South Perth Basin, Western Australia. 81 pp.

Sharifzadeh, A., 2008. Tight-Gas Resources in the Northern Perth Basin, Petroleum W.A. Magazine, 41-44.

Tobin, R.C., Mcclain, T., Lieber, R.B., Ozkan, A., Banfield, L.A., Marchand, A. M. E., McRae, L.E., 2010. Reservoir quality modeling of tight-gas sands in Wamsutter filed: Integration of diagenesis, petroleum systems, and production data. American Association of Petroleum Geologists Bulletin 94(8), 1229-1266.

Weber, K.J., 1980. Influence in fluid flow of common sedimentary structures in sand bodies. SPE Annual Technical Conference and Exhibition, Texas, USA, 21-24 September, SPE 9247.

Yao, T., Anil Chopra, A., 2000. Integration of seismic attribute map into 3D facies modeling. Journal of Petroleum Science and Engineering 27, 69-84. 


\section{Highlights}

- Reservoir properties of tight gas sandstones show intimate relationship with depositional facies and diagenetic features.

- Coarse grained sandstone facies of fluvial channels and crevasse splay contribute to the main reservoir units in the field.

- 3D modeling of tight gas sandstones unravels the reservoir heterogeneity related to sedimentary facies and diagenesis.

- Depositional characteristics have the main control on large scale reservoir heterogeneity, distribution of reservoir units, their thickness and continuity.

- Diagenesis has the main control on pore system properties and controlling the internal reservoir heterogeneity. 